University of Rhode Island

DigitalCommons@URI

Open Access Master's Theses

1981

\title{
Environmental Assessment of Industrial Development Hopkins Hill Industrial Zone, Coventry-West Greenwich, Rhode Island
}

Joel Rinebold

University of Rhode Island

Follow this and additional works at: https://digitalcommons.uri.edu/theses

\section{Recommended Citation}

Rinebold, Joel, "Environmental Assessment of Industrial Development Hopkins Hill Industrial Zone, Coventry-West Greenwich, Rhode Island" (1981). Open Access Master's Theses. Paper 703.

https://digitalcommons.uri.edu/theses/703

This Thesis is brought to you for free and open access by DigitalCommons@URI. It has been accepted for inclusion in Open Access Master's Theses by an authorized administrator of DigitalCommons@URI. For more information, please contact digitalcommons-group@uri.edu. 


\section{ENVIRONMENTAL ASSESSMENT \\ OF}

INDUSTRIAL

DEVELOPMENT

HOPKINS HILL INDUSTRIAL ZONE

Coventry - West Greenwich, Rhode Island

by

Joel Rinebold 


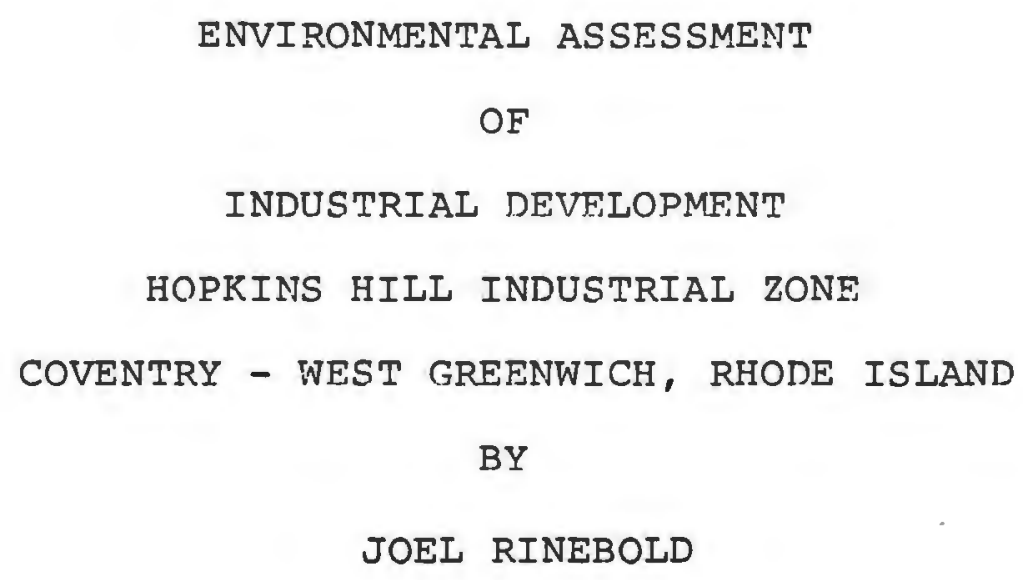

A MASTER'S RESEARCH PROJECT SUJBMITTED IN PARTIAL FULFILLMENT OF THE REOUIREMENTS FOR THE DEGREE OF MASTER OF COMMUNITY PLANNING 


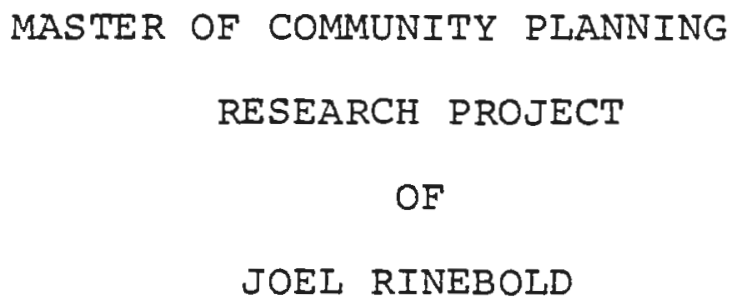

Approved:

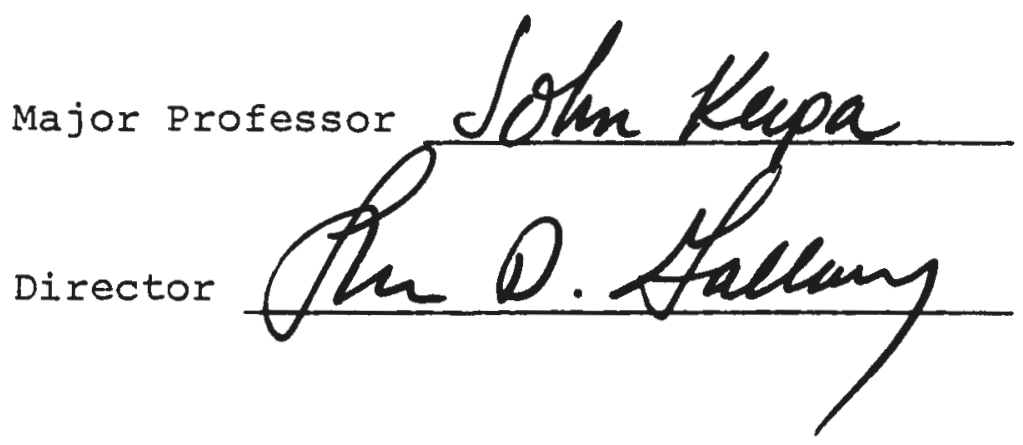

UNIVERSITY OF RHODE ISLAND

1981 


$$
\text { Dreface }
$$

one method used to identify, analyze and minimize environmental degredation from proposed develonment is the employment of an environmental imnact assessment. An environmental impact assessment can supply information which can be used to help locate and determine the type of development on a particular site.

The following is an environmental impact assessment for the coventry/hest Greenwich Tndustrial 7one. It is with areat expectations that this report will serve the residents of the state and users of the site by supplying the information necessary to preserve the integrity of the natura? environment while allowing maximum development. 
TABLE OF CONTENTS

Page

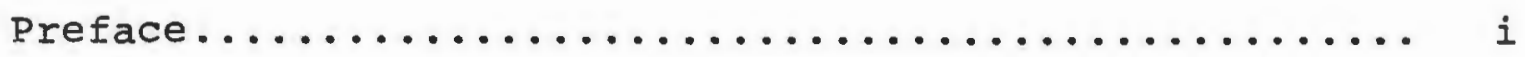

List of Figures....................... v

List of Tables........................ vi

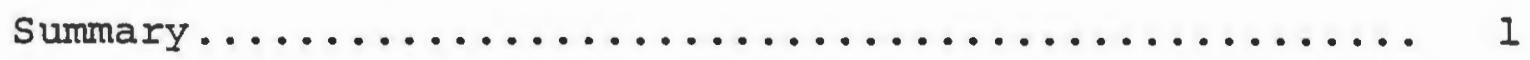

Chapter I INTRODUCTION................... 3

1. Project surroundings............ 3

2. Background................ 5

Chapter II ENVIRONMENTAI INVENTORY............ 10

1. Climate....................... 10

2. Geology....................... 10

3. Land Resources ................ 12

4. Water Resources................ 21

5. Air Resources ............... 32

6. Vegetation Resources............ 33

7. Wildlife Impacts............. 36

8. Acoustical Analysis............ 39

Chapter III ACTION AND ALTTRNATIVES.......... 45

Chapter IV ENVIRONMENTAL IMPACTS........... 47

1. Climate.................. 47

2. Geology ..................... 47

3. Land Impacts................ 47

4. Water Resources Impact........... 50

5. Air Resources Impact............ 54 
Page

Chapter IV ENVIRONMENTAL IMPACTS

6. Vegetation Impacts............... 54

7. Wildlife Impacts................ 56

8. Acoustical Impacts............... 58

Chapter $V$ ADVERSE ENVIRONMENTAL EFFECTS WHICH

CANNOT BE AVOIDED SHOULD INDUSTRIAL

DEVELOPMENT BE IMPLEMENTED.......... 67

Chapter VI MEASURES UNDER CONSIDERATION TO

MINIMIZE UNAVOIDABLE ENVIRONMENTAL

EFFECTS

Chapter VII DEVELOPMENT RECOMMENDATIONS AND THE

RELATIONSHIP BETWEEN LOCAL SHORT

TERM USES OF MAN'S ENVIRONMENT AND

MAINTENANCE AND FNHANCEMENT OF LONG

TERM PRODUCTIVITY.

Chapter VIII ANY IRREVERSIBLE AND IRRETRIEVABLE COMMITMENT OF RESOURCES WHICH WOULD

BE INVOLVED IN THE RECOMMENDED

ACTION, SHOULD IT BE IMPLEMENTED.

APPENDICES

Appendix A Industrial zoning Ordinances for

Coventry and west Greenwich........... 82

Appendix B Present and Future Runoff and

Discharge Rates................... 94

Appendix C Surface water Monitoring............. 109

Appendix D state water Quality Standards......... 111

Appendix E Ground-Water Monitoring............ 116

Appendix F Air Quality Monitoring and Standards.... 117

Appendix G New Source Review.................. 119 
Page

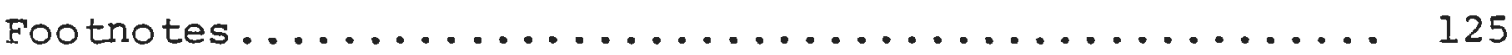

Bibliography........................... 127 
List of Figures

Page

Figure 1 Project Surroundings.................. 4

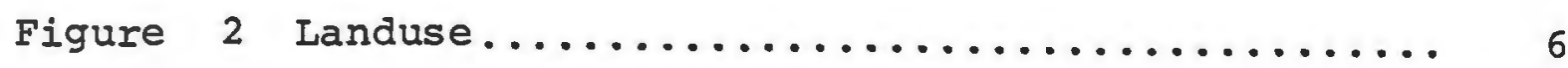

Figure 3 Study Area Location.................. 7

Figure 4 Utilities......................... 9

Figure 5 surficial Geology....................... 11

Figure 6 Soil Classification........................ 14

Figure 7 soils Suitable for Industrial Development.... 18

Figure 8 Soils Suitable for Agricultural Use........ 20

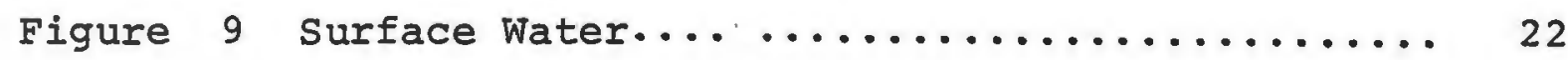

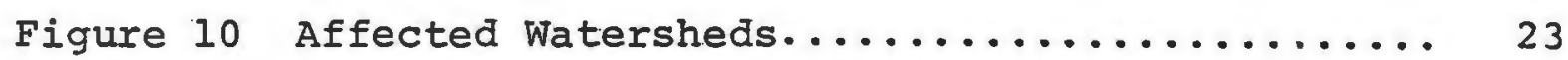

Figure 11 Ground-Water Flow .................... 29

Figure 12 water Monitoring Location.............. 31

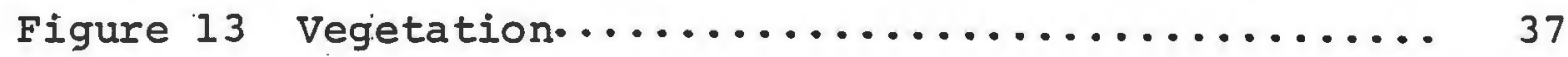

Figure 14 Acoustics; No Industrial Development, 1979... 42

Figure 15 Acoustical Design Point Locations ......... 59

Figure 16 Acoustics; No Industrial Development, 2000... 60

Figure 17 Acoustics; Limited Industrial Development, 200061

Figure 18 Acoustics; Full Industrial Development, 2000 • 62

Figure 19 Acoustical Comparison ................ 63

Figure 20 Recommended Development, Phase I......... 75

Figure 21 Recommended Development, Phase II........ 76

Figure 22 Recommended Development, Phase III........ 77

Figure 23 Recommended Development, Phase IV........ 78

Figure 24 Recommended Development, Final ............ 79 


\section{List of Tables}

Table

Title

Page

1

2

3

4

5

6

7

8

9

10

11
Soil Characteristics................. 16

Soil Development Limitations............ 17

Runoff and Discharge................ 27

Attainment Stature for Rhode Island....... 34

1979 Noise Analysis.................. 43

Surface Water Quality............... 52

Runoff and Discharge Impacts from........ 53 Full Industrial Development

Air Resources Impact from Mobile Sources... 55

Acoustical summary.................. 58

Projected Year 2000 Noise Impact,

No Industrial Development............. 65

Projected Year 2000 Noise Impact,

Iimited Industrial Development.......... 65

Projected Year 2000 Noise Impact,

Full Industrial Development. 


\section{SUMMARY}

Hopkins Hill Industrial Zone

Description of Project: Development of industrial activity in the Hopkins Hill Industrial Zone, Coventry/West Greenwich, Rhode Island.

Alternatives: Full industrial development; limited industrial development; no action (no industrial development).

Recommended Alternative: Phased use development with limited industrial activity.

Environmental Impact: The recommended alternative will assure optimum use of the site and surrounding facilities. Productirity can be measured by economic prosperity from industrial development; aquifer and water supply preservation; agricultural, wetland and forest land preservation; and limited mineral extraction. Some deep deposits of sand and gravel will not be mined in order to protect the underlying aquifer. The construction and operation of industrial activity will have some minor effects on acoustics, air, water, soils, vegetation and wildlife of the site.

Adverse Environmental Effects: Temporary increases in turbidity, erosion, dust and acoustic levels and their effects will result from construction operations. Possible damage to the Mishnock kame terrace aquifer and Piogue Lake may occur from surface water runoff pollution. Some 
displacement of vegetation and wildlife will have a slight impact on the site ecology. Acoustic and air pollution levels will be slightly increased from the increase of industrial related traffic. 


\section{Chapter I}

\section{INTRODUCTION}

\section{Project Surroundings}

Because of a shortage of useable prime undeveloped industrial land in Rhode Island, development pressure on the site has increased steadily. ${ }^{1}$ This assessment is concerned with a large contiguous tract of land about 635 acres in size. Approximately 71 percent of the site is within the borders of the town of Coventry. The remaining 29 percent is located in the town of West Greenwich, Rhode Island

The towns of Coventry and West Greenwich are classified as ex-urban which describes towns with population densities less than 2000 persons per square mile. In contrast are the nearby urban cities of West Warwick, Warwick, Cranston and Providence. The closest urban center to the site is that of West Warwick which is less than three miles away. Providence, the state's metropolitan hub and capital, is approximately eleven miles northeast of the site and is easily reached via Interstate Route 95 (see Figure 1). Approximately 2000 feet southwest of the site is the area proposed for the Big River Reservoir/Flood Project. When complete, the reservoir will have a surface area of 3400 acres at a water supply elevation of 300 feet above mean sea level. The entire watershed, owned by the Rhode Island Water Resources Board is approximately 18,970 acres in size. ${ }^{2}$ 


\section{Figure 1. PROJECT SURROUNDINGS}

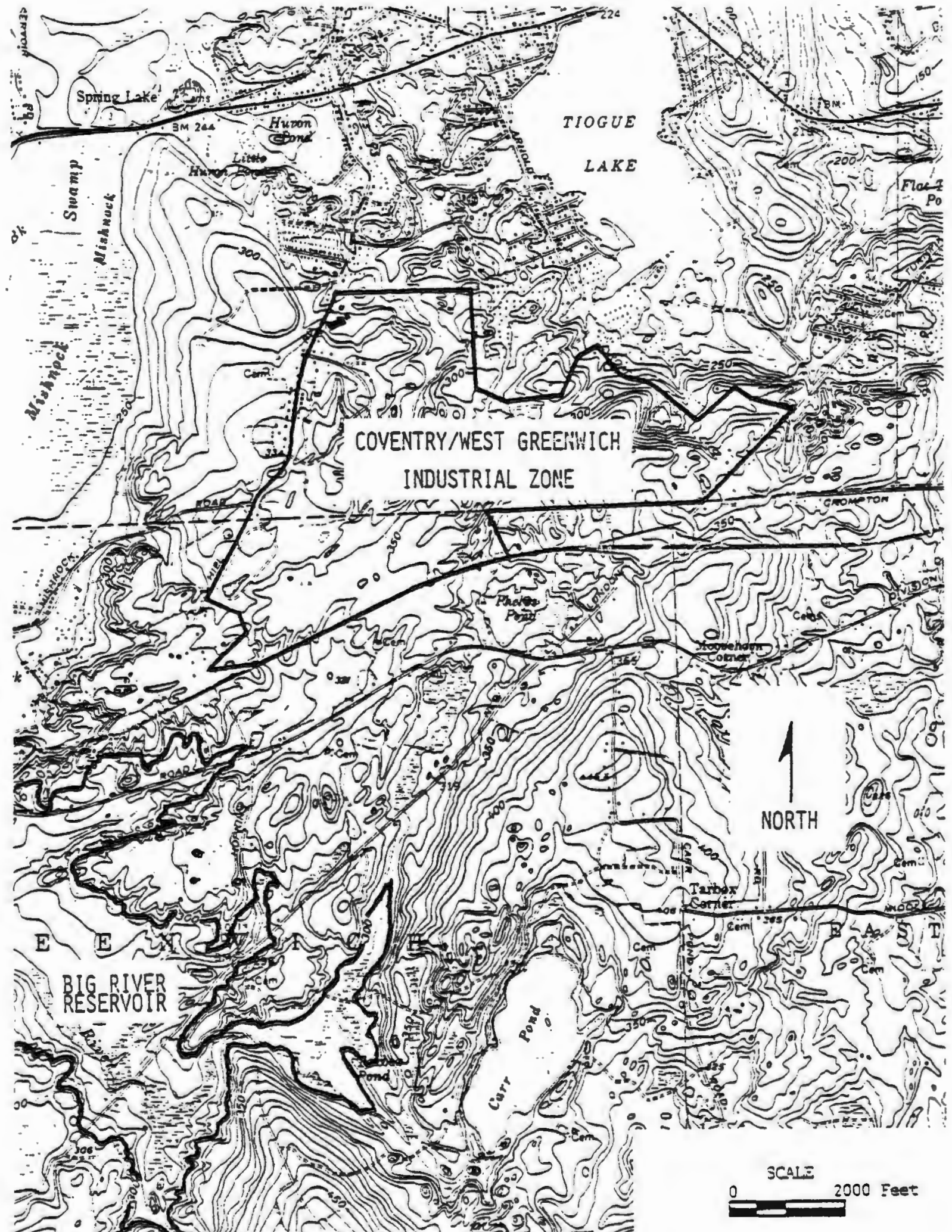


The land surrounding the site is largely undeveloped. However, north of the area there is substantial residential and commercial development, while south of the area is a large sand and gravel quarry. Zoning adjacent to the site is entirely residential with the exception of some quarry activity that operates as a legal non-conforming use. Landuse within the site varies from a scattering of residential and industrial uses along the interior perimeter to extensive quarry operations that penetrate into the central areas of the site. A large section of the site has been used as pasture land with other large sections in wooded forest land (see Figure 2). Access to the site may be gained from Hopkins Hill Road, Arnold Road, or the New London Turnpike. More important is the proximity of access onto the Interstate Highway System. Two interchanges, the planned Hopkins Hill Road/Interstate 95 interchange and the New London Turnpike Interstate 95 interchange, are located within 1000 feet of the site. This will allow a direct linkage of the site to the rest of the state and nation.

\section{Background}

In an effort to promote economic vitality both West Greenwich and Coventry have determined the need for more industrial development. Having recognized the study site as a potential industrial site, the towns have designated adjacent tracts of land as an industrial zone (see Appendix A). 


\section{Figure 2. Landuse}

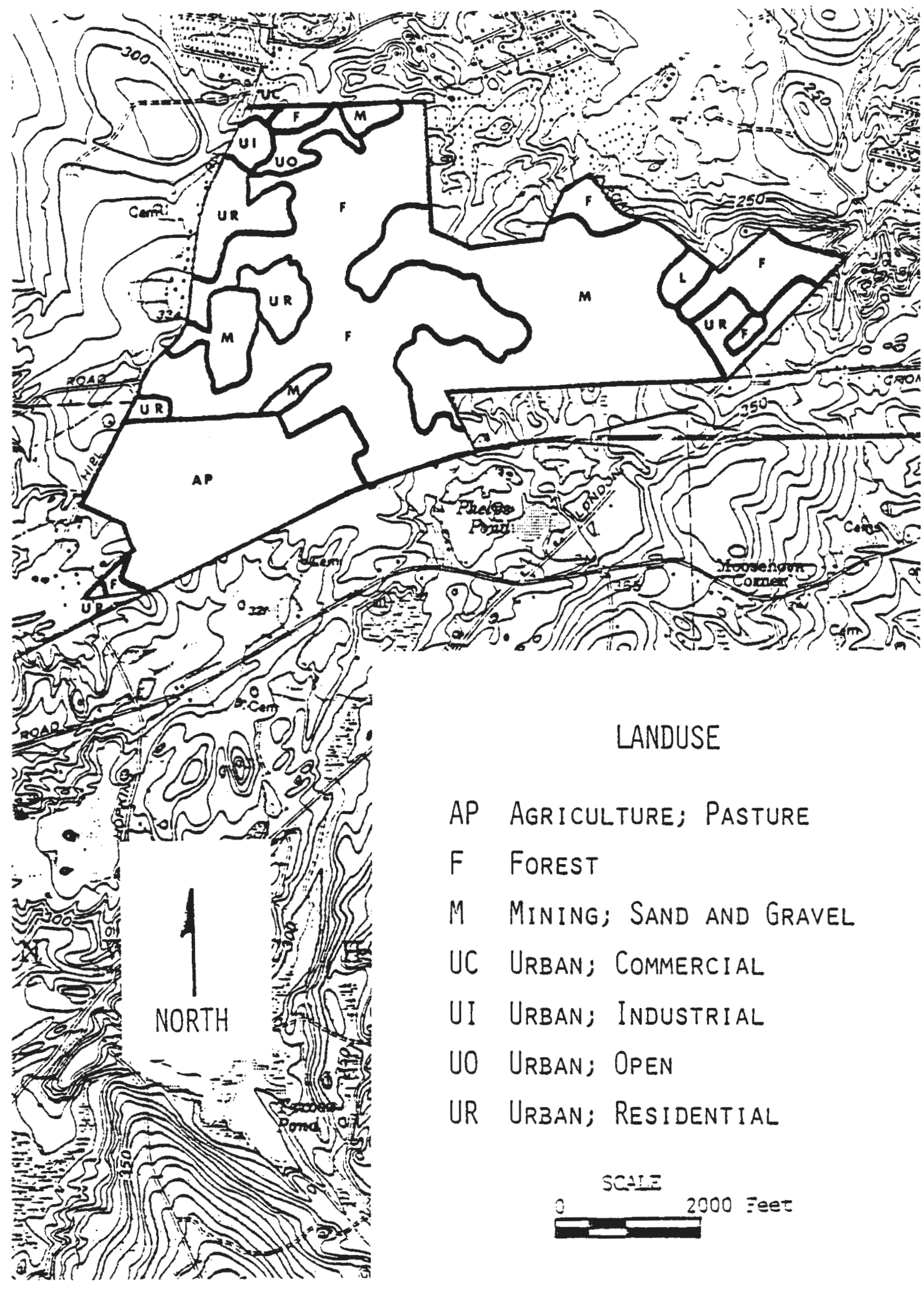


Figure 3. STUdY AREA LOCATION

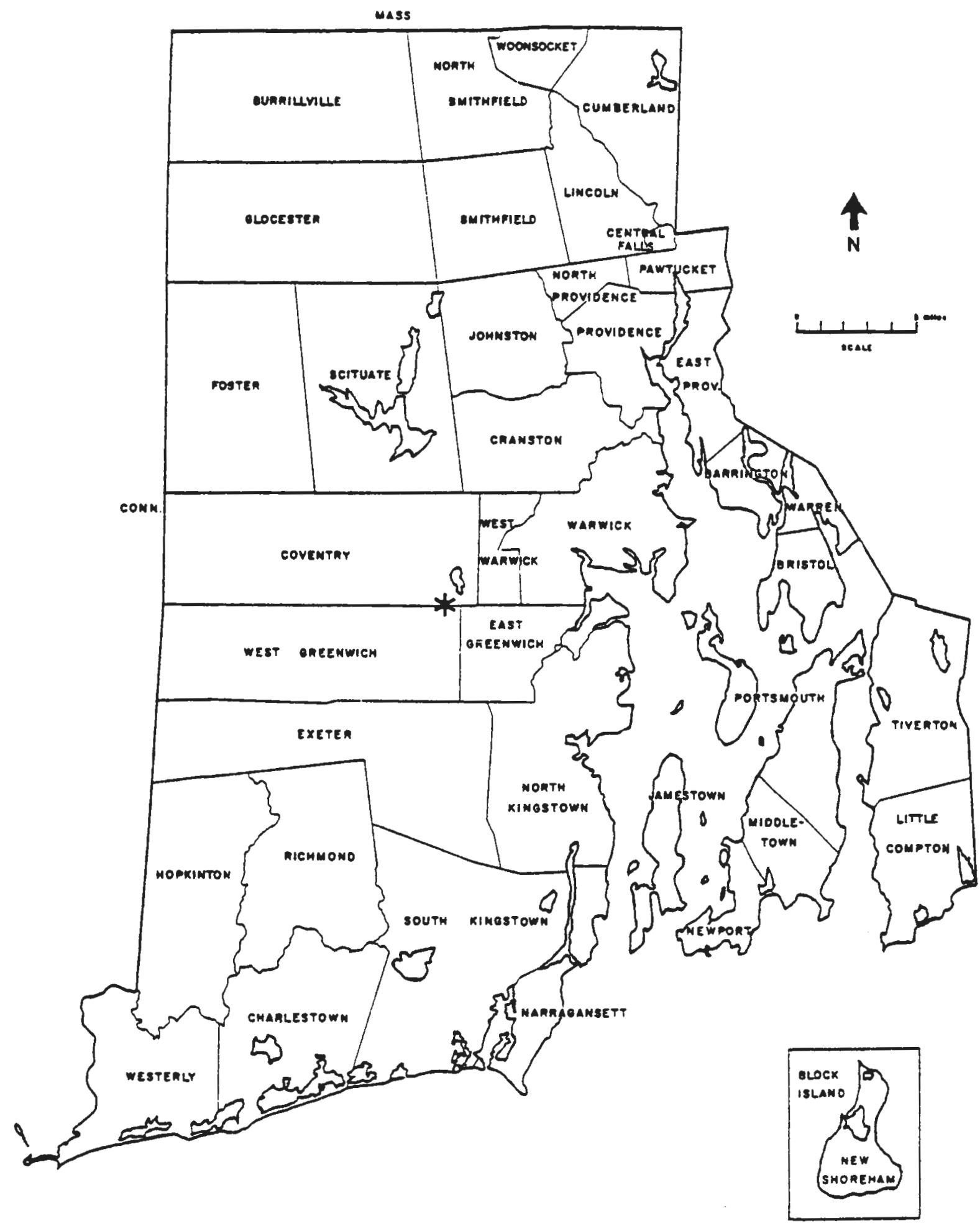

* Study Area 
It is now zoning policy of both towns to permit and develop the area industrially. Approximately 147 acres of the site were purchased on October 18, 1978 by the Rhode Island Port Authority and Economic Development Corporation through the Rhode Island Department of Economic Development. It has been the state's objective to promote industrial development on the parcel. On July 25, 1980 this parcel was sold to Digital Equipment Corporation which expects to develop the property industrially.

All utilities, i.e., electric, gas, water, and sewers, are available on the site (see Figure 4 ). The most recent utility is a 15 inch part gravity flow/part force main sewer line. It was extended to the site by an agreement between the State of Rhode Island and the Town of West Warwick.

With the expectation of full industrial development the State of Rhode Island Department of Transportation has determined that additional access to I-95 was needed. New access will be via a future Hopkins Hill Road/I-95 interchange. ${ }^{3}$ The future interchange was designed on the assumptions of full industrial development with 6000 employees and 19,000 trips per day. ${ }^{4}$ The alternative choosen was a half-diamond/partial cloverleaf interchange. The proposed action also includes the future upgrading of Hopkins Hill Road. 
Figure 4، Utilities

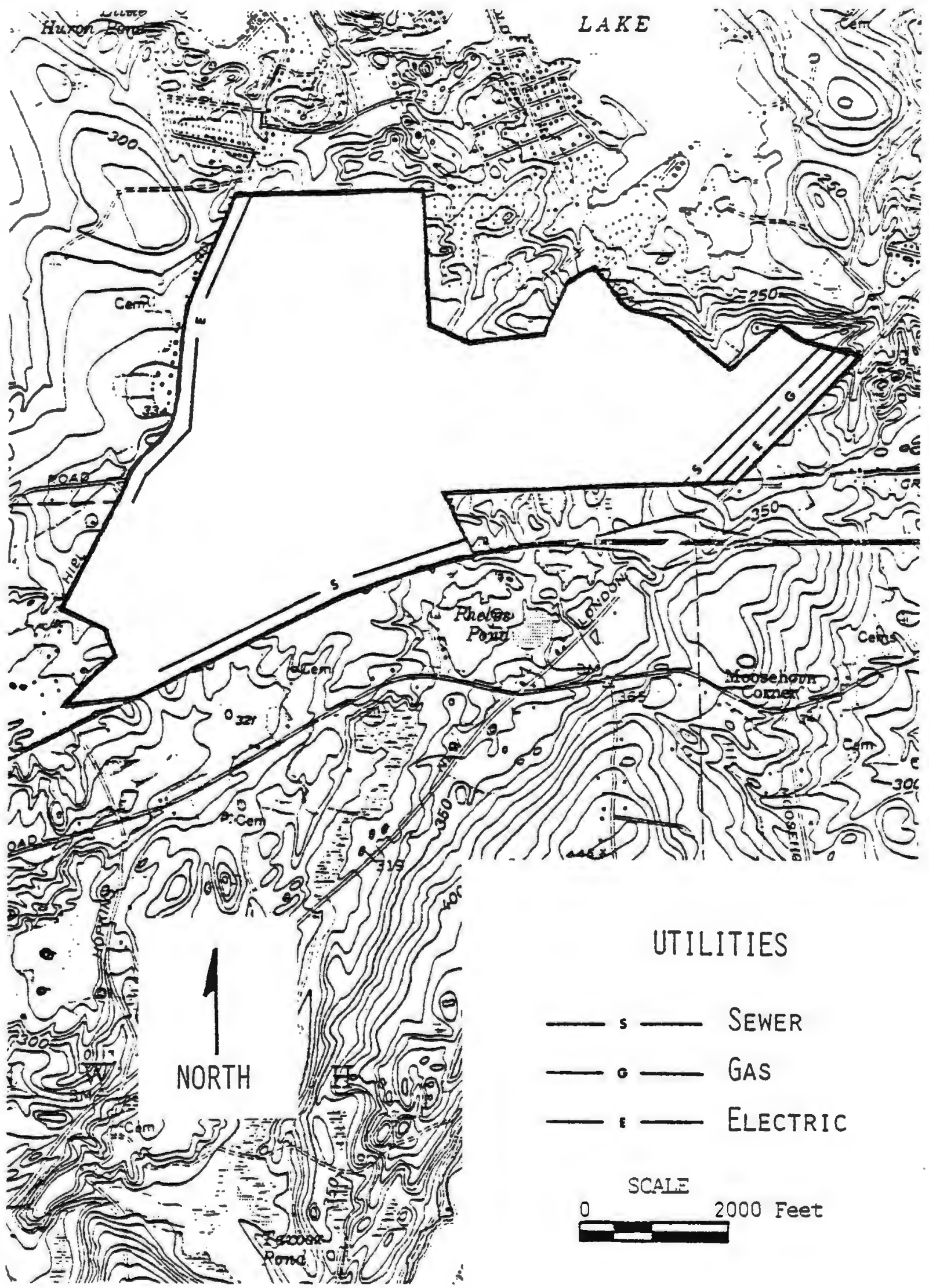


Chapter II

ENVIRONMENTAL INVENTORY

1. Climate 5

The climate of the site, as is all of Phode Island, is strongly influenced by the presence of the Atlantic Ocean and Narragansett Bay. Temperatures are moderated by the maritime environment in both summer and winter. The average annual temperature is about $50^{\circ} \mathrm{F}$. The coldest months, January and February, average about $29^{\circ} \mathrm{F}$ and the hottest month, July, averages $72^{\circ} \mathrm{F}$. Precipitation varies from year to year with an average annual rainfall of 42 inches. Most of the rainfall is associated with frontal activity except in the summer months when thunderstorms are frequent. The thunderstorms are accompanied by strong winds and heavy rainfall for short durations. It is not uncommon for local isolated flooding to occur.

2. Geology 6

The geologic resources of the site include large deposits of varied surficial materials. The predominant geological features of the site are an unconsolidated kame terrace and local deposits of undifferentiated sand and gravel. The kame terrace, named the Mishnock kame terrace, is composed of glacially stratified drift. It was deposited by glacial meltwater streams between ancient valley walls and the adjacent mass of glacial ice lying in the valley. It is probable that the nearby deposits of ground moraine on the higher elevations represent the valley walls that were formed by the southeast moving ice (see Figure 5). 


\section{Figure 5. SURFICIAL GEOLOGY}
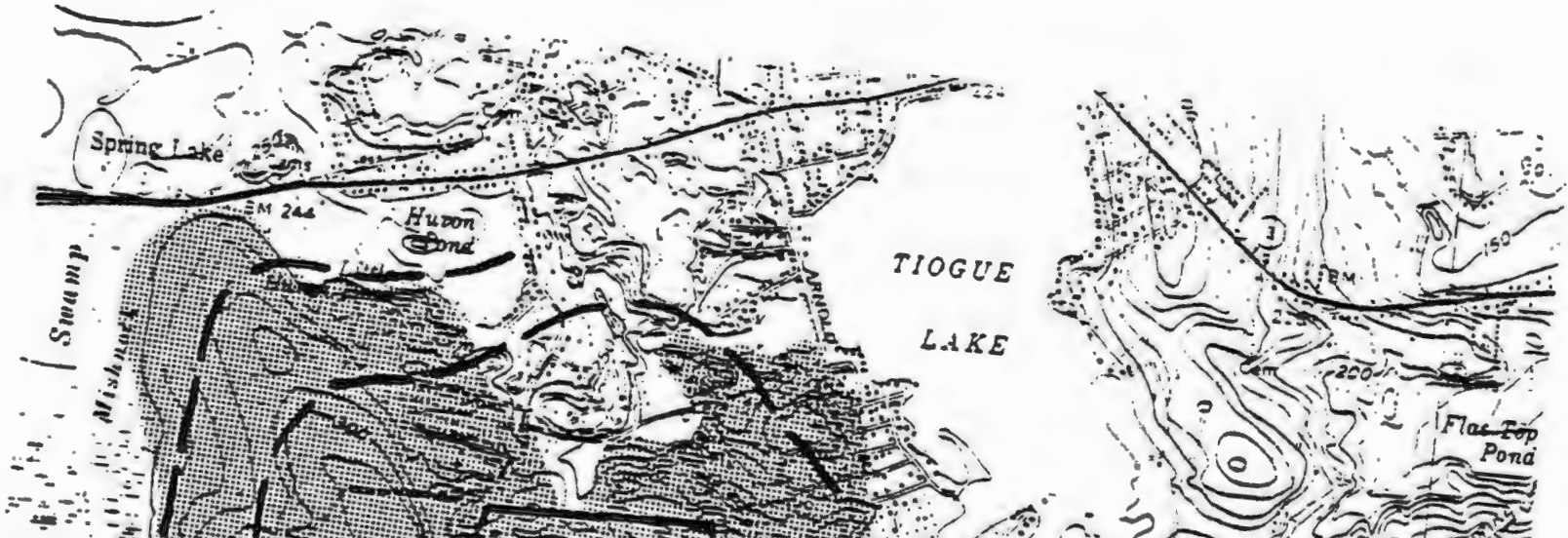

-

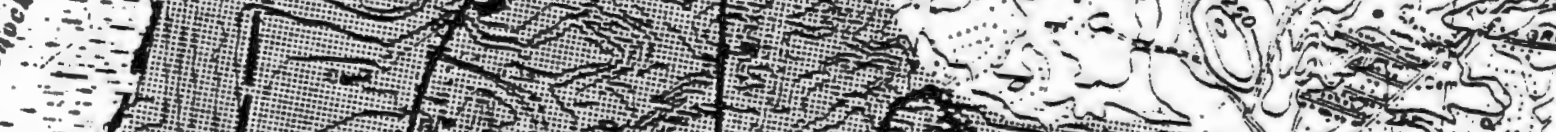

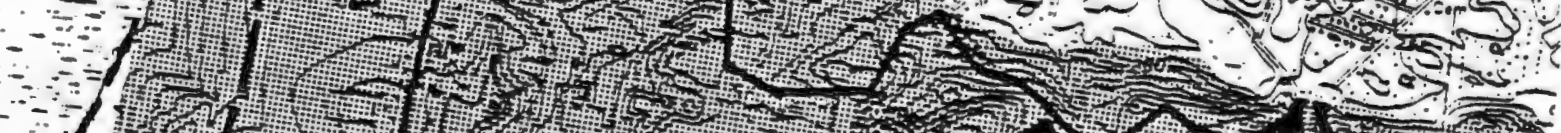

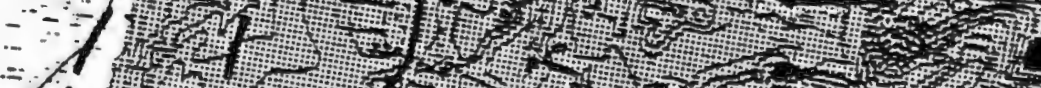

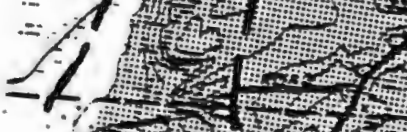

of

(1)

Plo (1)

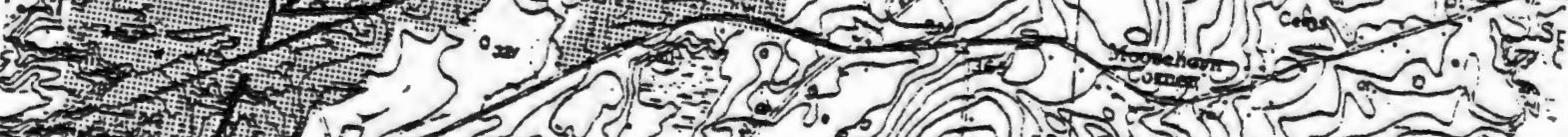
30.50 (2)
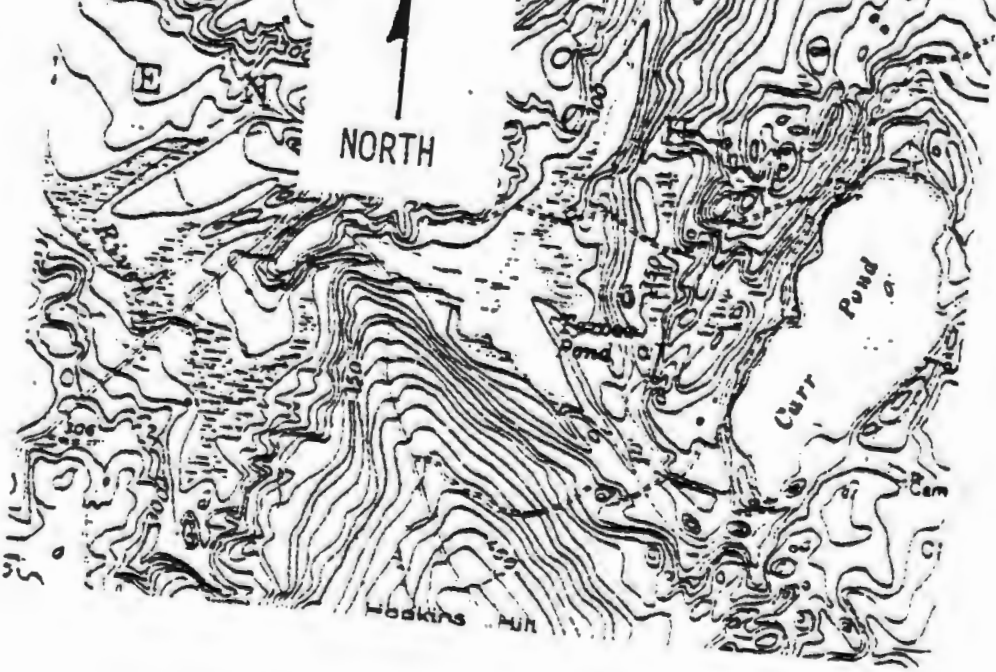

\section{SURFICIAL GEOLOGY}

- REDROCK ELEVATION

- Sand and Gravel

BOULDERS

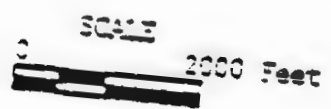


The undifferentiated deposits of sand and gravel were probably deposited in pools of meltwater caused by the last remaining blocks of ice. These kettle deposits as they are called are isolated and small, but several of them may be found on the site.

In general, the rocks are of granitic origin and range in size from sand to boulder. The beds show stratification, but due to slump and other disturbances irregular beds and tilting may be observed.

The depth of the drift ranges from 50 to 135 feet, being deepest in the valleys. Under the surficial kame lies a consolidated basement bedrock of granite. The great volume and quality of the kame terrace makes it a valuable economic and hydrologic resource. The entire site has a large potential supply of commercial quality sand and gravel. The stratified drift also serves as an excellent aquifer. Even at the present time both commercial surface mining companies and private water companies are operating on the site. A more detailed account of surface mining operations and ground-water resources will be made in the Land Resources and Water Resources sections respectfully.

\section{Land Resources}

The land resources of the study area include soil resources, sand and gravel resources, and potential for agricultural and silvicultural activities. Each of these resources will be examined below. 
Soil Resources

Soil analyses show slight to moderate building constraints for most areas of the site. The most prevalent problem is the difficulty in establishing vegetation on cuts due to droughty soil conditions.

The following soil explanation points out the major characteristics that are likely to affect industrial development actions. 7

Gloucester-Hinckley Complex (15.xc)

This soil occurs in a complex pattern characterized by a stoney composition high in sand. Permeability is rapid and the available moisture is low.

Merrimac Series (17A, 17B)

This soil is moderately permeable and has a moderate moisture holding capacity. It is well suited for most uses. Hinkley Series $(27 \mathrm{~A}, 27 \mathrm{C})$

This soil is an excessively drained soil with very rapid permeability. The water table is greater than 48 inches below the surface.

Hinkley-Enfield Complex (28C)

This soil occurs in a complex pattern characterized by excessive drainage with moderate to very rapid permeability. Although much of this soil is easily worked and free of stones, irrigation and fertilizer apolication is necessary for agricultural activities. 
FigURE 6, SOIL CLASSIFICATION
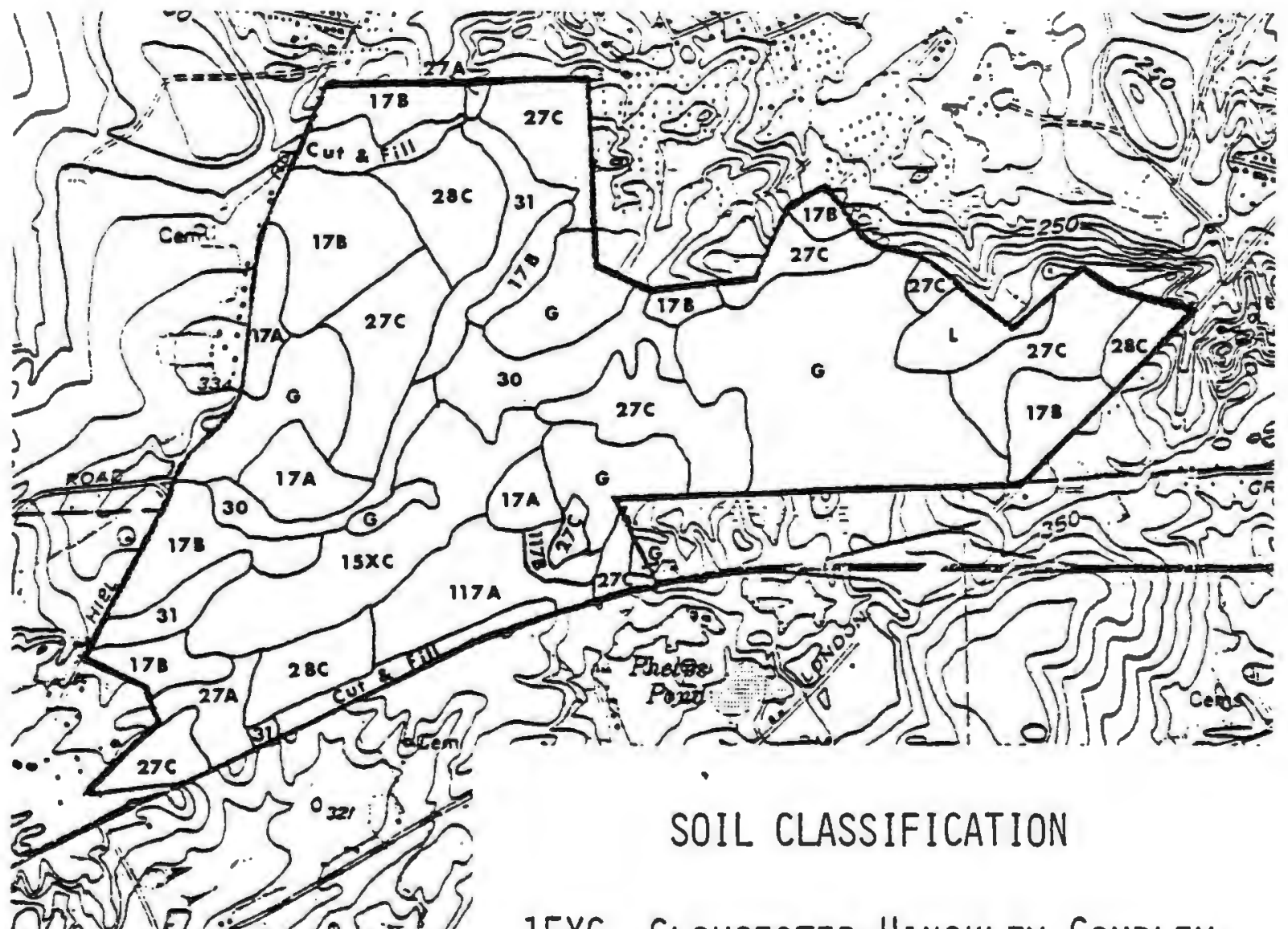
Tive 10 (e) a d o

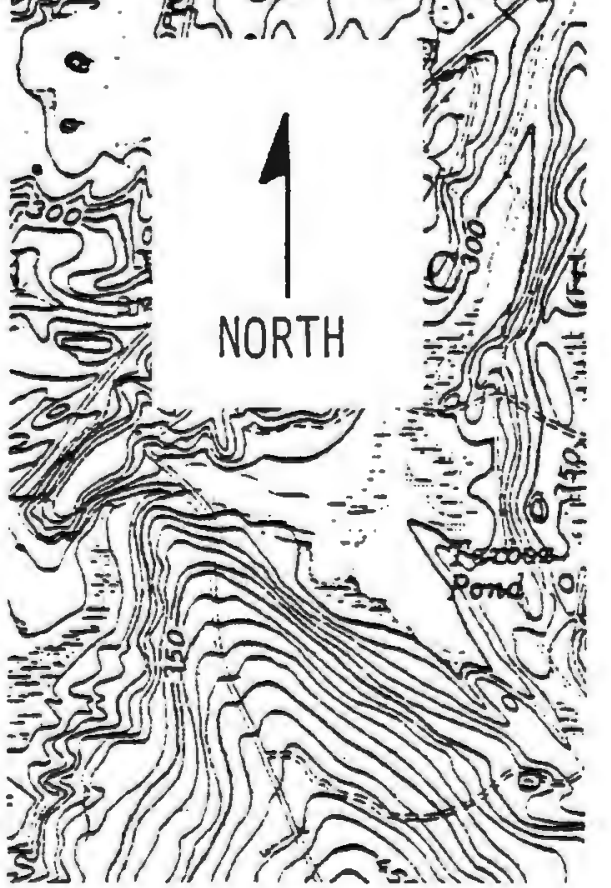

$15 X C$ Gloucester-Hinckley Complex

17A Merrimac Series

17B Merrimac Series

27A HinCKLEY SERIES

27C Hinckley Series

30 Walpole Series

31 SCARboro SERIES

117a Agawam Series

117B Agawam Series

$G$ SAND AND GRAVEL QUARRY

L LANDFILL

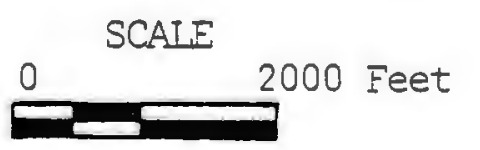


Walpole series ( 30$)$

These are poorly drained coarse textured soils. The water table is at or near the surface from late fall through early spring.

Scarboro Series (31)

These are very poorly drained coarse textured soils. The water table is at or near the surface most of the year. Ponding occurs frequently during and after heavy rains.

Agawam Series (117A, 117B)

This is a deep, well drained soil with moderately rapid permeability and a moderate moisture holding capacity. It is well suited for agricultural and residential uses.

Sand and Gravel Surface Mine Areas

Most soils have been removed leaving the surficial geology or water table exposed. Grading and artificial fill will be needed for most types of industrial development.

\section{Landfill Areas}

This area has serious limitations for any structural development. The layers of decomposing solid waste produces rapid uneven settling and the generation of toxic methane gases. All proposals for structural development should be discouraged for the area. 


\begin{tabular}{|c|c|c|c|c|c|c|}
\hline \multirow{2}{*}{$\begin{array}{l}\text { Soil } \\
\text { Type }\end{array}$} & \multirow[b]{2}{*}{ Texture } & \multirow{2}{*}{$\begin{array}{l}\text { Depth to } \\
\text { Seasonal } \\
\text { High water } \\
\text { Table (feet) }\end{array}$} & \multirow{2}{*}{$\begin{array}{l}\text { Susceptability } \\
\text { to Frost } \\
\text { Action }\end{array}$} & \multicolumn{3}{|c|}{ Suitability as a Source of } \\
\hline & & & & $\begin{array}{l}\text { Top } \\
\text { Soil }\end{array}$ & $\begin{array}{l}\text { Sand } \\
\text { Gravel }\end{array}$ & Road Fill \\
\hline $15 \times C$ & $\begin{array}{l}\text { Gravelly to sandy loam, } \\
\text { loamy sand over } \\
\text { gravelly sand, sand } \\
\text { and gravel }\end{array}$ & 4 & Low & Poor & Good & Good \\
\hline $17 \mathrm{~A}$ & $\begin{array}{l}\text { Sandy loam over sand } \\
\text { and gravel }\end{array}$ & 4.0 & Low & Fair & Good & Good \\
\hline $17 \mathrm{~B}$ & $\begin{array}{l}\text { Sandy loam over sand } \\
\text { and gravel }\end{array}$ & 4.0 & Low & Falx & Good & Good \\
\hline $27 \mathrm{~A}$ & $\begin{array}{l}\text { Gravelly sandy loam } \\
\text { over sand and gravel }\end{array}$ & 4.0 & Low & Poor & Good & Good \\
\hline $27 \mathrm{C}$ & $\begin{array}{l}\text { Gravelly sandy loam } \\
\text { over sand and gravel }\end{array}$ & 4.0 & Low & Poor & Good & Good \\
\hline $28 \mathrm{C}$ & $\begin{array}{l}\text { Silty to gravelly } \\
\text { sandy loam over sand } \\
\text { and gravel }\end{array}$ & 6.0 & Moderate & Poor & $\begin{array}{l}\text { Good } \\
\text { below } \\
2 \text { feet }\end{array}$ & $\begin{array}{l}\text { Good } \\
\text { below } \\
2 \text { feet }\end{array}$ \\
\hline 30 & $\begin{array}{l}\text { Sandy loam over sand } \\
\text { and gravel }\end{array}$ & $.5-1.5$ & Moderate & Poor & $\begin{array}{l}\text { Good } \\
\text { below } \\
2.5 \text { feet } \\
\end{array}$ & Poor \\
\hline 31 & $\begin{array}{l}\text { Loamy fine sand over } \\
\text { loamy sand or sand }\end{array}$ & $0-.5$ & Moderate & Poor & $\begin{array}{l}\text { Good } \\
\text { below } \\
2.5 \text { feet }\end{array}$ & $\begin{array}{l}\text { Fair } \\
\text { below } \\
2.5 \text { feet }\end{array}$ \\
\hline $117 \AA$ & $\begin{array}{l}\text { Fine sandy loam over } \\
\text { sand, loamy gand }\end{array}$ & 4 & Moderate & Good & Good & Good \\
\hline $117 \mathrm{~B}$ & $\begin{array}{l}\text { Fine sandy loam over } \\
\text { sand, loamy sand }\end{array}$ & 4 & Moderate & Good & Good & Good \\
\hline
\end{tabular}

Source: U.S. Department of Agriculture, Rhode Island Soil Interpretation Tables 


\begin{tabular}{|c|c|c|c|c|c|}
\hline \multirow{2}{*}{$\begin{array}{l}\text { Soil } \\
\text { Type }\end{array}$} & \multicolumn{3}{|c|}{ Limitations for } & \multirow{2}{*}{$\begin{array}{l}\text { Surface } \\
\text { Soil } \\
\text { Erodib } 111 \text { ty } \\
\text { Factor (K) }\end{array}$} & \multirow{2}{*}{$\begin{array}{l}\text { General Development } \\
\text { Constraint }\end{array}$} \\
\hline & $\begin{array}{c}\text { Structure with } \\
\text { basement }\end{array}$ & Landscaping & $\begin{array}{l}\text { Roads and } \\
\text { Stree ts }\end{array}$ & & \\
\hline $15 Y C$ & $\begin{array}{l}\text { Moderate: } \\
\text { stoniness }\end{array}$ & $\begin{array}{l}\text { Moderate: } \\
\text { droughty }\end{array}$ & $\begin{array}{l}\text { Moderate: } \\
\text { Slope }\end{array}$ & .17 & $\begin{array}{l}\text { Droughty, difficuit } \\
\text { to estabilsh vegetation }\end{array}$ \\
\hline $17 \mathrm{~A}$ & slight & $\begin{array}{l}\text { Moderate; } \\
\text { drough ty }\end{array}$ & SIIght & .17 & $\begin{array}{l}\text { Droughty, difficult to } \\
\text { establish vegetation } \\
\text { on cuts }\end{array}$ \\
\hline ITB & SIight & $\begin{array}{l}\text { Maderate: } \\
\text { drough ty }\end{array}$ & slight & .17 & $\begin{array}{l}\text { Droughty, difficult to } \\
\text { establish vegetation } \\
\text { on cuts }\end{array}$ \\
\hline $27 \bar{A}$ & Slight & $\begin{array}{l}\text { Severe: } \\
\text { droughty }\end{array}$ & slight & .17 & $\begin{array}{l}\text { Droughty, difficult to } \\
\text { establish vegetation }\end{array}$ \\
\hline $27 \mathrm{C}$ & $\begin{array}{l}\text { Moderate: } \\
\text { slopes }\end{array}$ & $\begin{array}{l}\text { Severe; } \\
\text { droughty }\end{array}$ & $\begin{array}{l}\text { Moderate } \\
\text { slopes }\end{array}$ & .17 & $\begin{array}{l}\text { Droughty, difficult to } \\
\text { establish vegetation }\end{array}$ \\
\hline $28 \mathrm{C}$ & $\begin{array}{l}\text { Moderate: } \\
\text { slopes }\end{array}$ & $\begin{array}{l}\text { Severe: } \\
\text { droughty }\end{array}$ & $\begin{array}{l}\text { Moderate; } \\
\text { slopes } \\
\text { frost action }\end{array}$ & .17 & Erosive \\
\hline $301:$ & $\begin{array}{l}\text { Severe: } \\
\text { high wa ter } \\
\text { table }\end{array}$ & $\begin{array}{l}\text { Severe; } \\
\text { high water } \\
\text { table }\end{array}$ & $\begin{array}{l}\text { Severe } \\
\text { high water } \\
\text { table }\end{array}$ & .20 & High water table \\
\hline 31 & $\begin{array}{l}\text { Very severe: } \\
\text { high water } \\
\text { table }\end{array}$ & $\begin{array}{l}\text { Very severe: } \\
\text { high water } \\
\text { table }\end{array}$ & $\begin{array}{l}\text { Very severe: } \\
\text { high water } \\
\text { table }\end{array}$ & $=$ & High water table \\
\hline $117 \mathrm{~A}$ & SIight & Slight & $\begin{array}{l}\text { Moderate: } \\
\text { frost action }\end{array}$ & .28 & $\begin{array}{l}\text { Droughty, difficult to } \\
\text { establish vegetation } \\
\text { on cuts }\end{array}$ \\
\hline $117 \overline{8}$ & slight & Slight & $\begin{array}{l}\text { Moderate: } \\
\text { frost action }\end{array}$ & .28 & $\begin{array}{l}\text { Droughty, difficult to } \\
\text { establish vegetation } \\
\text { on cuts }\end{array}$ \\
\hline
\end{tabular}


Figure 7. SOILS SUITABLE FOR INDUSTRIAL DEVELOPMENT

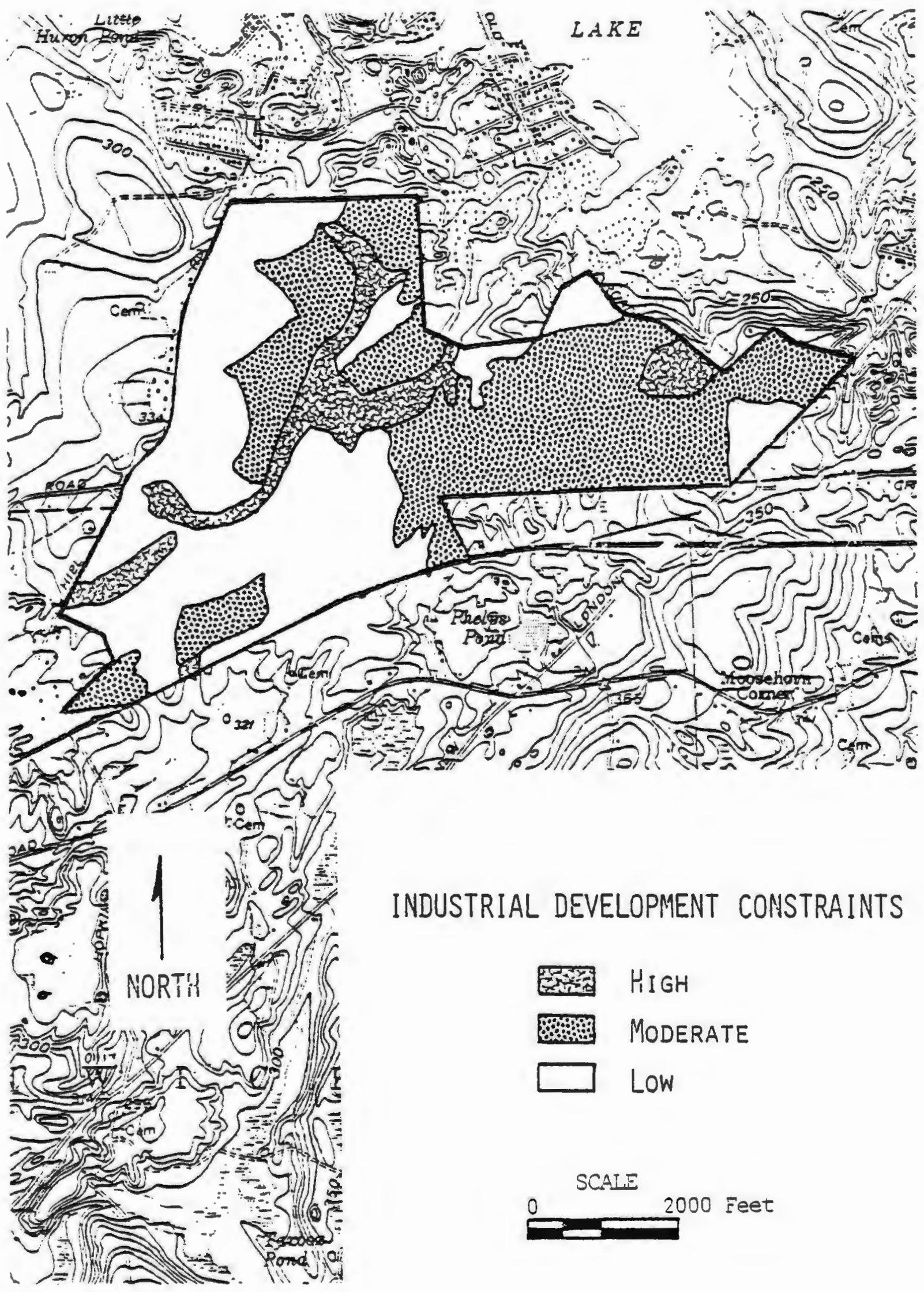


Sand and Gravel Resources

There are significant quantities of sand, gravel and stone in the study area. According to the state's aggregate survey, reserves in Coventry and West Greenwich are 4435 and 4921 thousand cubic yards respectfully, but not all of this can be considered available for exploitation because local ordinances, zoning restrictions, and preemptive uses prohibit mining. 8

Production of these resources for commercial use is an important part of the Rhode Island mineral industry. In the area of the Pawtuxet River Basin, 2,389,000 short tons of all sand and gravel were produced at a value of $\$ 2,914,000$ in 1970 . This was actually a decline in the 1969. production by 91,000 short tons and $\$ 102,000 .^{9}$

The towns of Coventry and West Greenwich may have the greatest potential for sand and gravel exploitation in the state. With demand increasing and supplies dwindling, it is assumed that pressure to continue and expand mining operations on the site will increase in the future.

\section{Agriculture and Silviculture Potential}

Approximately 178 acres, $28 \%$ of the site, exhibits soils suitable for prime agricultural or silviculture activities. The soils that lend themselves to these uses are the Merrimac sandy loams and Agawam fine sandy loams. Other soils of the site are not suitable for these activities due to sandy, droughty, or high water table conditions. 
FiguRe 8, SOILS SUITABLE FOR AgRICULTURAL USE

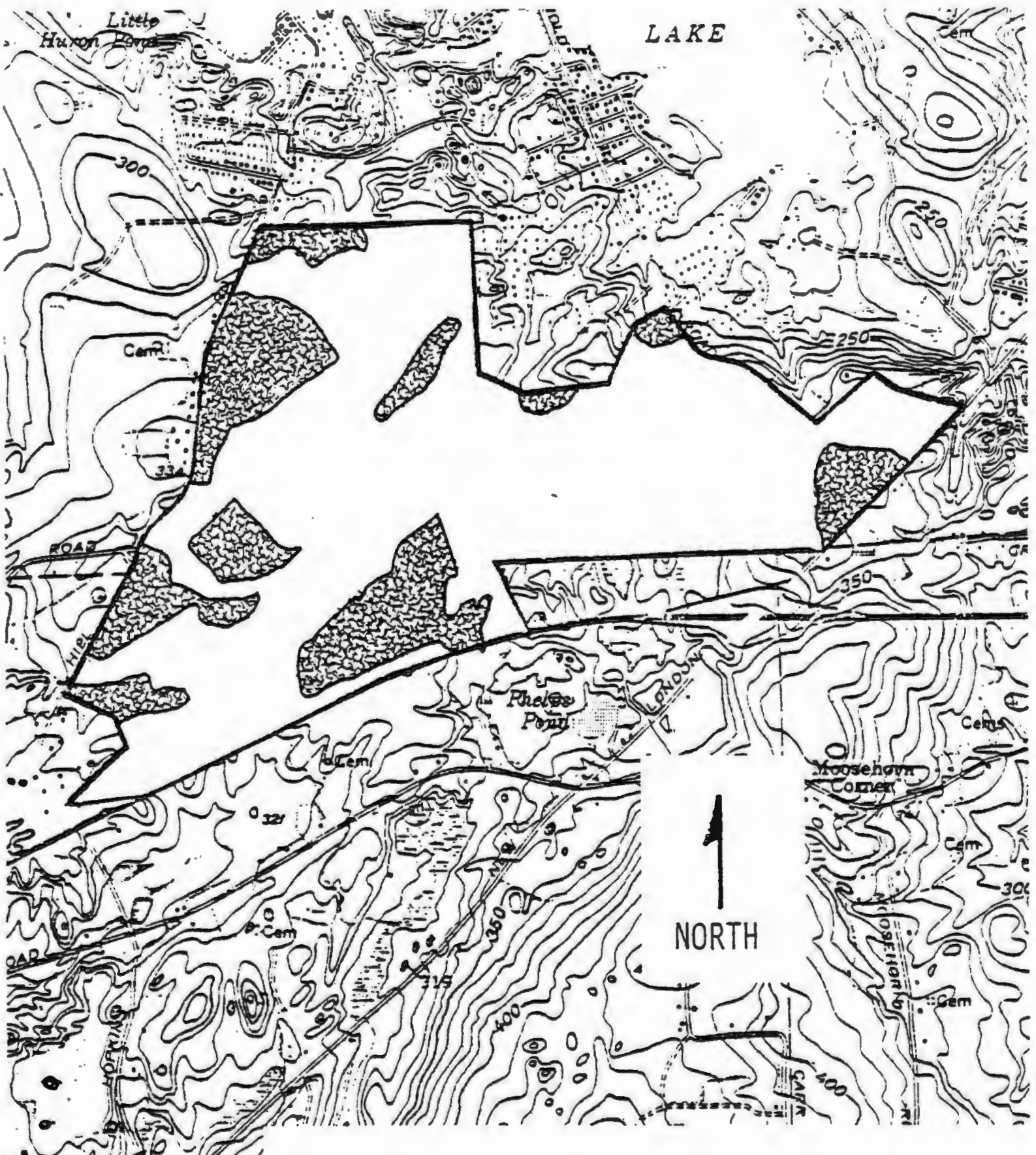

viline-

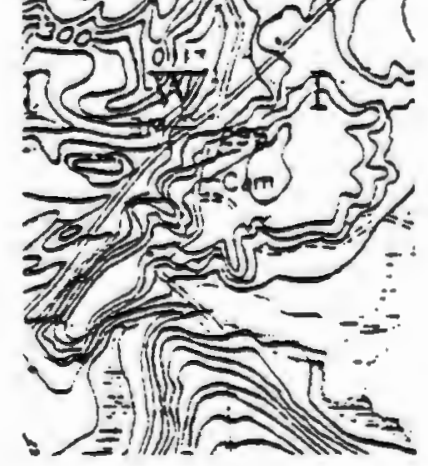

SOILS SUITABLE FOR AGRICULTURAL LSE 


\section{Water Resources}

On the site there exists water resources in the form of small unnamed streams, small surface water bodies and ground-water.

The streams and water bodies drain into major surface water resources which are located only a short distance from the study area. These major surface water resources include Mishnock River, Mishnock Swamp, old Hickory Brook, Carr River, Flat River, Big River, Tiogue Lake and the South Branch Pawtuxet River (see Figure 9).

The surface water resources can best be assessed in terms of the respective watersheds. The site is divided into five first order watersheds (see Figure 10). The majority of the site runoff is discharged to Tiogue Lake, but some site runoff also flows into the Upper Mishnock River and an unnamed tributary of the Carr River. The following is a description of the surface water resources for each of the watersheds that intersect the site.

Upper Mishnock River Watershed (Number 1)

This watershed includes Lake Mishnock, the upper Mishnock River and Mishnock Swamp. Lake Mishnock is a 58 acre artificial impoundment nearly surrounded by residential dwellings. Water from Lake Mishnock flows into the Upper Mishnock River which is approximately 4 feet wide and 12 inches deep. Surrounding the river is Mishnock Swamp. This is a rather large undeveloped wetland that occupies about one fourth the area of the 


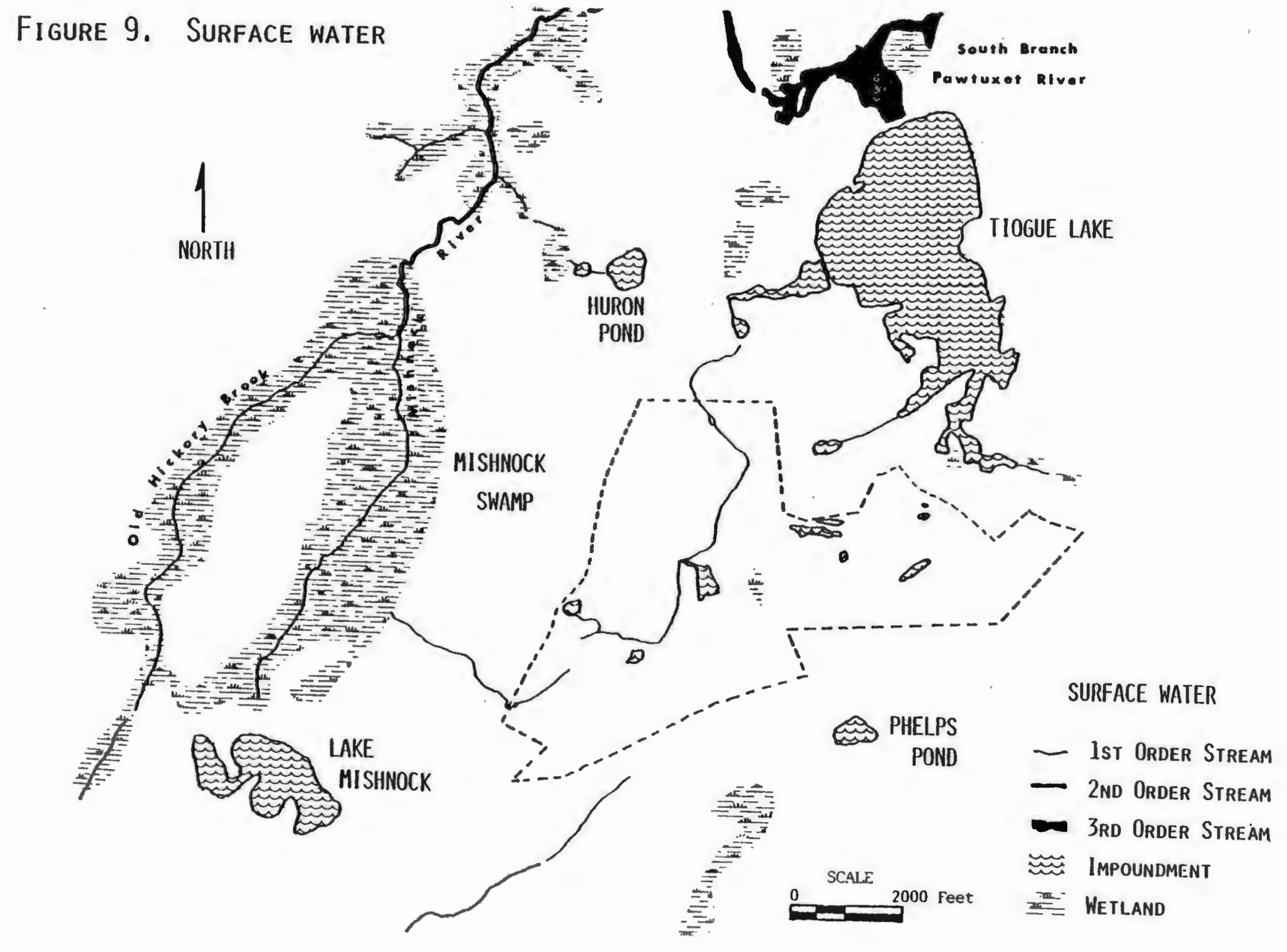


Figure 10. Affected Watersheds

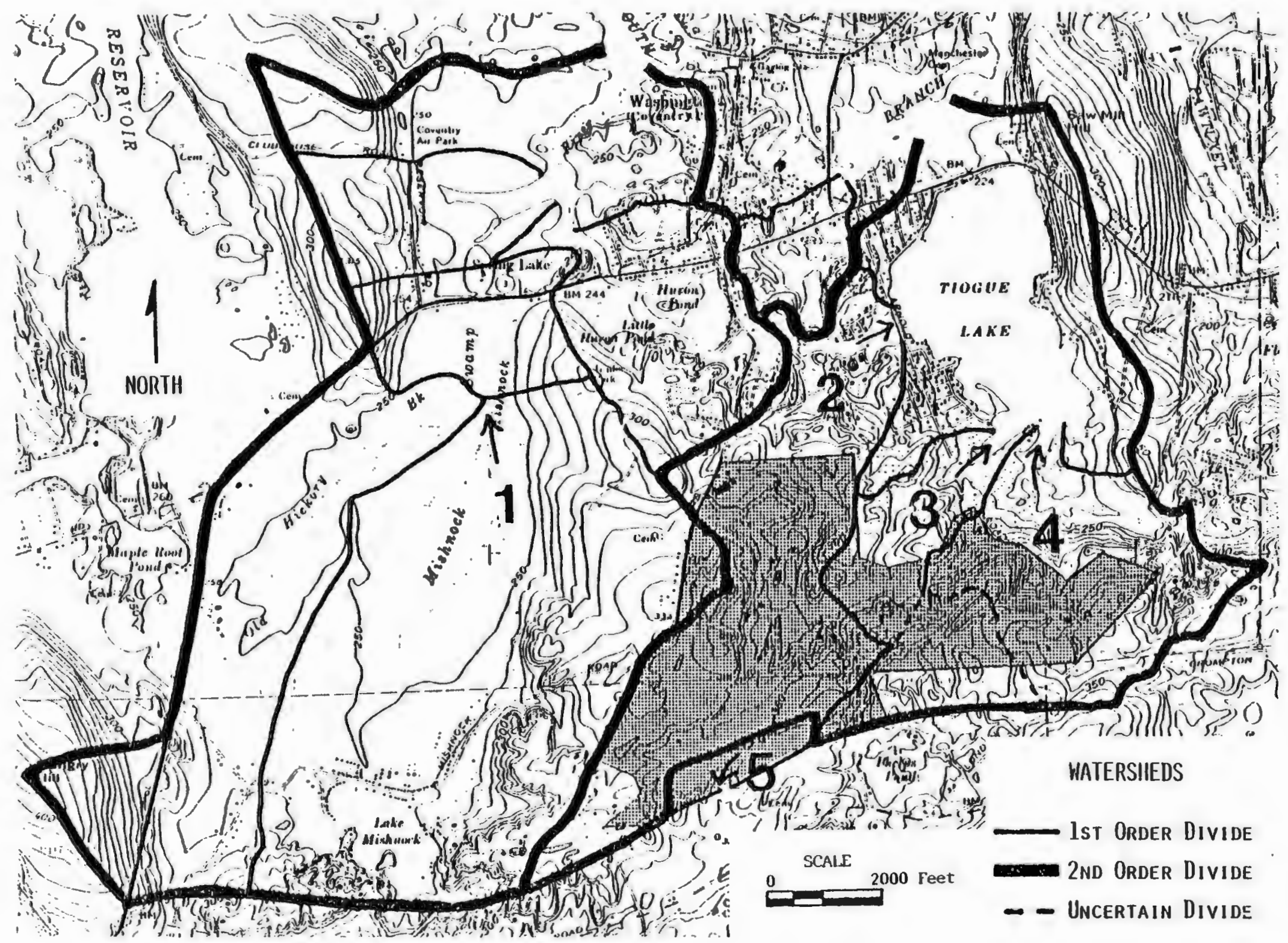


watershed. Water flows north and eventually empties into the South Branch of the Pawtuxet River.

Watershed Number 2

The surface water resources of this watershed include a small intermittent stream, small drainage depressions and a small shallow pond. The stream drains several small depressions which periodically dry up in the summer months. It also drains the major surface water body of the site. This is a small shallow pond primarily surrounded by forest vegetation. There is evidence that water from this impoundment is partially used for industrial purposes. The water then flows into Tiogue Lake and into the South Branch Pawtuxet River.

Watershed Number 3

Several small drainage depressions created from mining operations are located in this watershed. Runoff from the site flows into these depressions which act like retention basins before running off the site and into a well defined pond and stream. Surface runoff flows north and eventually empties into Tiogue Lake.

The upper reaches of this watershed has uncertain boundaries. This is mainly due to the altered topography that has resulted from surface mining operations. 
Watershed Number 4

This watershed also contains altered topography and several mining depressions. Water from this watershed flows north over the site to a small wetland area before entering a large inlet in Tiogue Lake.

Watershed Number 5

This small watershed is the result of artificial boundaries formed by Route I-95. It is the upper most part of a much larger watershed of an unnamed tributary of the Carr River. Runoff of the site flows south under the highway through a conduit and into this unnamed tributary. It then flows into the Carr River and eventually into the Big River and Flat River Reservoir. Runoff will flow into the Big River Reservoir when the project is completed. As mentioned previously, the Big River Reservoir is a flood control/water supply project to be completed in the near future.

All five of the described watersheds are largely undeveloped and contain well drained soils resulting in low runoff rates for all of the watersheds. In all cases the calculated runoff curve number was less than 60 . A minimum weighted runoff curve number of 60 was used in calculating the runoff and discharges for each of the watersheds. This was done to insure compatibility with Department of Agriculture, Soil Conservation Service calcuiations and tables. 10 other variables used in determining runoff rates are statistical storm event 
rainfall in inches and specific types of landuses within each of the watersheds. Table 3 gives a summary of the runoff rates for each of the watersheds. More detailed calculations are provided in Appendix B.

Discharge rates for each watershed are also calculated and summarized in Table 3. These discharge rates are given in cubic feet per second, and based on runoff rates, slope, watershed shape, size and the presence of ponding or swampy areas. More detailed tables are given in Appendix B for discharge calculations.

The study area has abundant ground-water resources. The widespread occurance of glacial outwash material, 50 to 135 feet thick throughout the general area serves as an excellent aquifer (see Figure 5). The coarse grained outwash material contains a large volume of pore space. This pore space becomes filled with water from rainfall and other types of precipitation. Thus, the water is held in a large slow moving underground reservoir. Well logs from the general area indicate at least 15 square miles of outwash material 50 or more feet thick. Assuming a uniform saturated thickness of 50 feet and a specific yield of 10 per cent the amount of available water in storage would be 15 billion gallons. ${ }^{11}$ properly constructed wells can yield 250 to $600 \mathrm{gpm}$ with an average depth to water being about 12 feet. ${ }^{12}$ such large quantities of ground-water have great potential for future water supply sources. 
Table 3 Runoff and Discharge

\begin{tabular}{lcccc}
\hline Storm Event & $\begin{array}{c}10 \\
\text { year }\end{array}$ & $\begin{array}{c}25 \\
\text { year }\end{array}$ & $\begin{array}{c}50 \\
\text { year }\end{array}$ & $\begin{array}{c}100 \\
\text { year }\end{array}$ \\
\hline $\begin{array}{l}\text { 24 Hour rainfall } \\
\text { (inches) }\end{array}$ & 5.0 & 5.5 & 6.5 & 7.1 \\
\hline $\begin{array}{l}\text { Runoff in inches for } \\
\text { all watersheds }\end{array}$ & 1.3 & 1.6 & 2.3 & 2.7 \\
\hline $\begin{array}{l}\text { Discharge (cfs) for: } \\
\text { Watershed Number 1 }\end{array}$ & 152 & 201 & 323 & 420 \\
Watershed Number 2 & 130 & 173 & 269 & 337 \\
Watershed Number 3 & 64 & 88 & 135 & 176 \\
Watershed Number 4 & 158 & 205 & 316 & 402 \\
Watershed Number 5 & 87 & 107 & 153 & 180 \\
\hline
\end{tabular}


The coarse permeable outwash and slope of the water table indicate that the surface water is hydraulically connected with the ground-water reserves. Taking into account the high permeability of the outwash material and the northern slope of the bedrock surface, it can be assumed that the flow of ground-water is reasonably fast and takes a northward direction (see figure 11).

Water cuality

The surface water quality of the site has been classified by the Rhode Island Department of Environmental Management, Division of Water Resources. All surface water on the site has been classified as Class $B$, with the exception of the small tributary in watershed 5 which is classified as a Class A stream. This stream has been classified as a class A stream because of its flow into the Big River, also a Class A stream and future water supply source.

Below is a description of the fresh water classification system used in Rhode Island.

Class A - (drinking) water supply

Class B - public water supply with appropriate trea tment

- agricultural uses

- bathing, other primary contact recreational activities

- fish and wildlife habitat 
Figure 11: GROUND-WATER fLOW

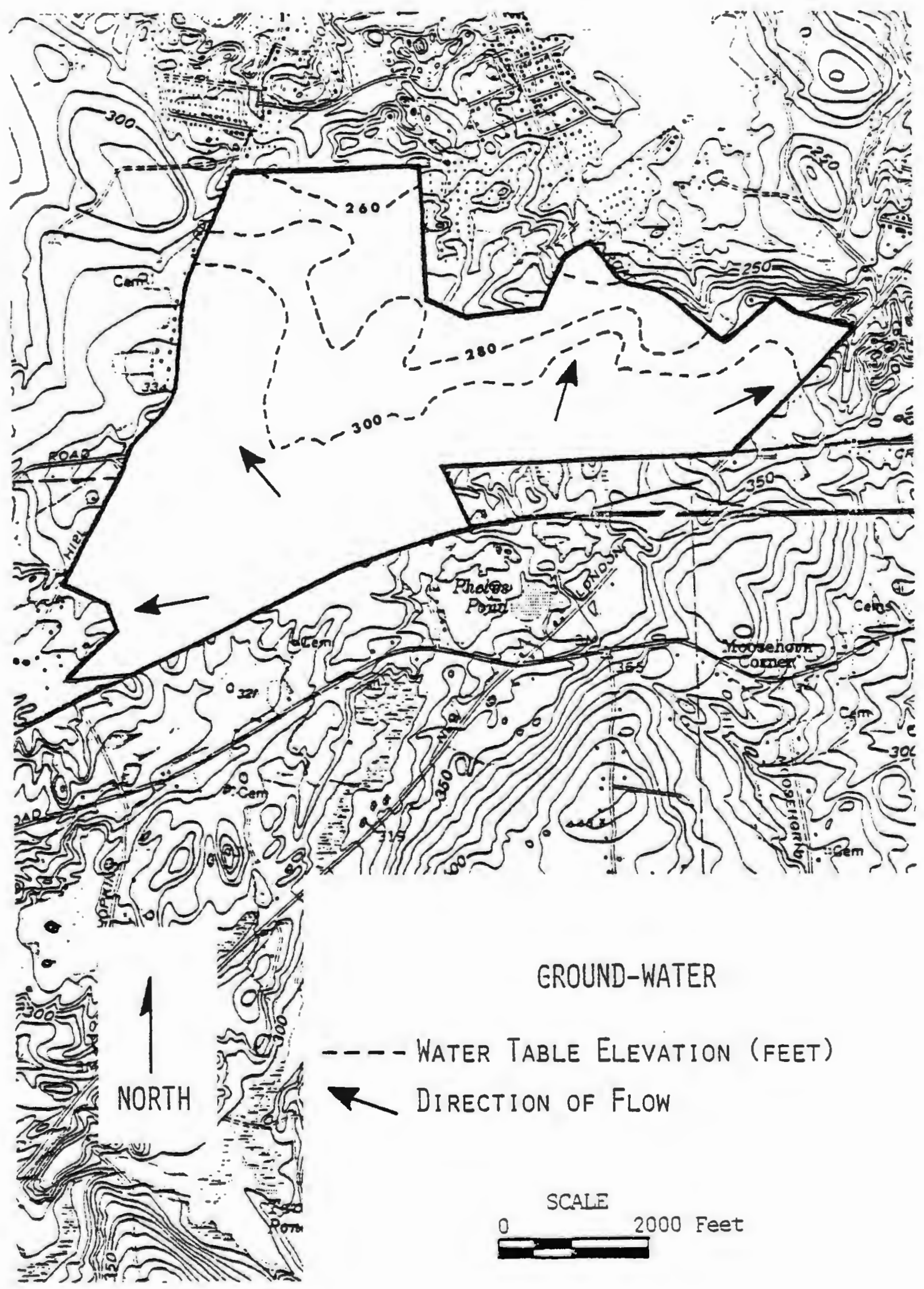




$$
\begin{aligned}
& \text { Class C - boating, other secondary contact } \\
& \text { recreational activities } \\
& \text { - fish and wildlife habitat } \\
& \text { - industrial processes and cooling } \\
& \text { Class D - migration of fish } \\
& \text { - good aesthetic value } \\
& \text { Class E - Nuisance conditions; uses limited to: } \\
& \text { - certain industrial processes and cooling } \\
& \text { - power } \\
& \text { - navigation }
\end{aligned}
$$

Although no specific surface water testing for the site has been made, monitoring has been made at watershed design points in Tiogue Lake (see Figure 12). The monitoring data shows trace elements of industrial pollutants, but they are not in violation of the Rhode Island Water Quality Regulations for water Pollution Control. It is assumed that some of the pollutants have come to the site from the now closed coventry landfill and historical discharges from operating and now closed industry on the site. A more precise account of monitoring data and state water quality standards can be found in Appendix $C$ and Appendix $D$ respectfully.

Nearby water supply wells owned by the Kent County Water Authroity have been periodically monitored for quality. It can be assumed that this data is indicative of the general ground-water quality of the site due to 
FigURE 12. WATER MONITORING LOCATIONS

和

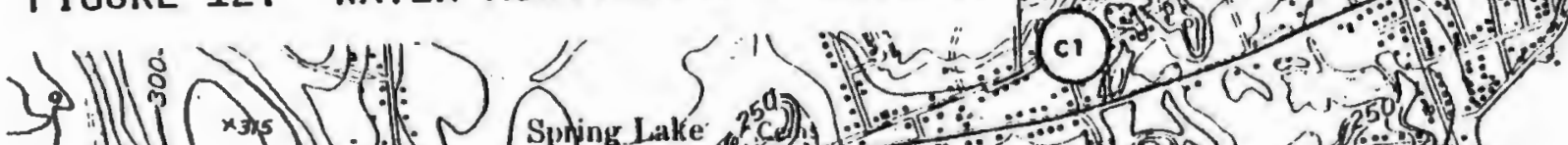
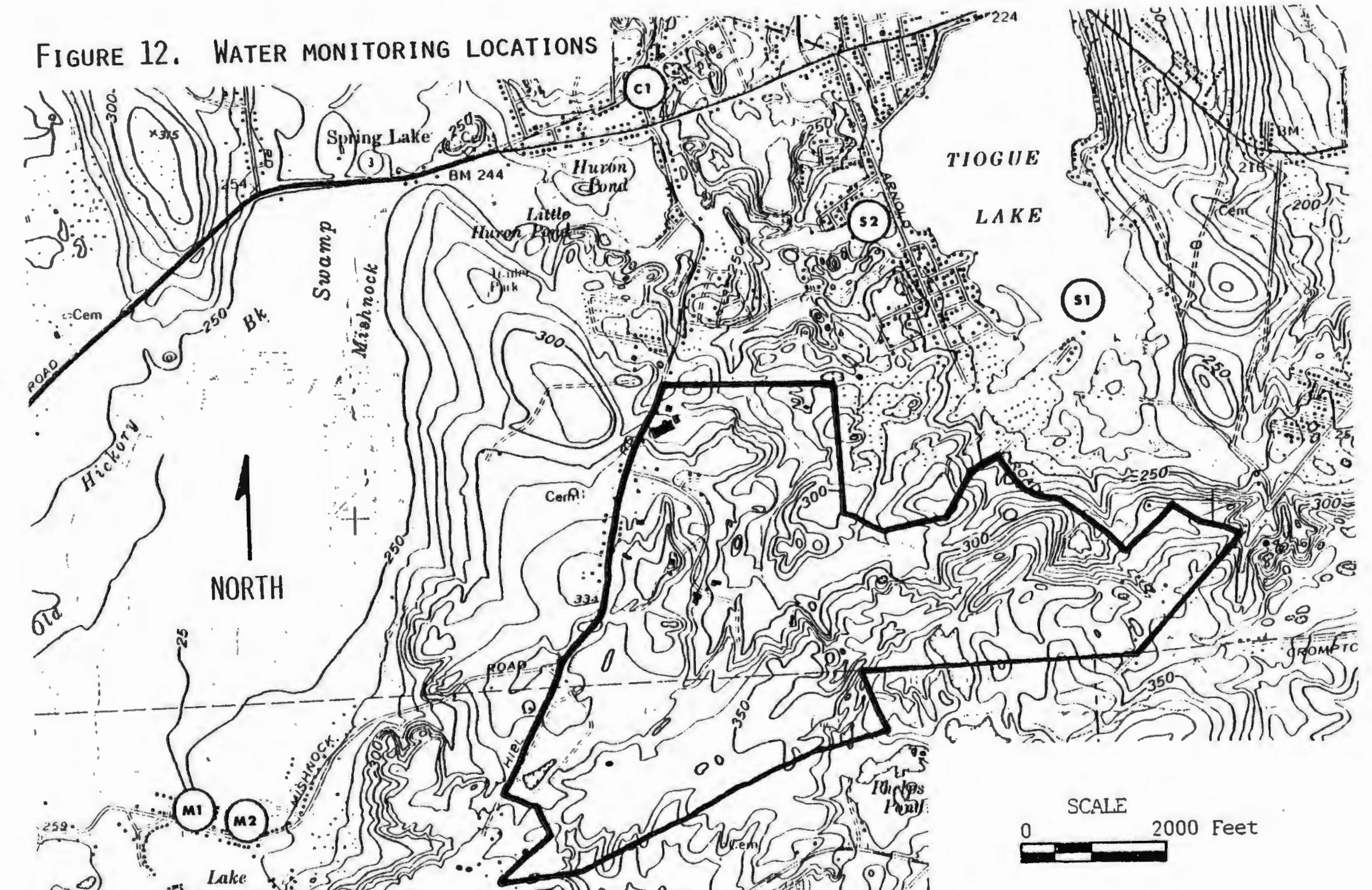
(1) , (1. (1) - 70

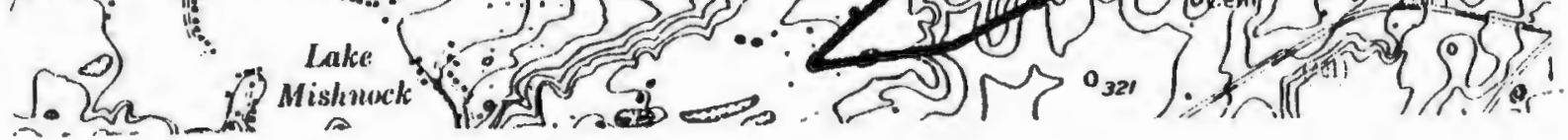


the hydraulic connection of the entire Mishnock kame terrace aquifer. However isolated areas of unknown water quality is possible and probably exists. This is due to isolated historical dumpings and discharges and the relatively slow travel rate of pollutants in ground-water. These areas are very difficult to assess without extensive ground-water monitoring data which is presently not available.

In general, the monitoring indicates that the groundwater of the site is of high quality and may be used for public water supply without treatment. A more detailed account of water quality monitoring data may be found in Appendix E.

\section{Air Resources}

Air resources of the site will be assessed in terms of the Clean Air Act. This Federal Act sets primary and secondary air quality standards. Primary standards are designed to protect human health and secondary standards are designed to protect property and aesthetics. The State Divisions of Air and Hazardous Materials and Occupational Health and Radiation Control are responsible for the implementation of the Act. As of 1979, they have 15 active monitoring stations set up throughout the state. Air quality monitoring at the $w$. Alton Jones Campus, University of Rhode Island, West Greenwich will be used as an indicator of air quality on the site. This state 
monitoring station is approximately $6.5 \mathrm{miles}$ southwest of the study area.

The air quality monitoring data indicates that the site is normal for non-metropolitan areas of Rhode Island. Table 4 shows attainment status in respect to Clean Air Act standards for Rhode Island. The only pollutant that is positively above the standards is ozone. Even after the 1979 relaxation of the ozone standard from $160 \mathrm{ug} / \mathrm{m}^{3}$ to $235 \mathrm{ug} / \mathrm{m}^{3}$, the entire state is classified as nonattainment. Total suspended solids and sulfer dioxide have levels that are lower than the national standards. The site cannot be classified for carbon monoxide or nitrogen dioxide due to a lack of monitoring data. Air quality monitoring data and the National Ambient Air Quality Standards are listed in Appendix F.

\section{Vegetation Resources}

A large part of the site is forested. The predominent tree species are oak, hickory, and pine. It has been determined that some of the forest areas in the study area are well suited for commercial wood production activities. Even at the present time, many of the large stands of white pine are being logged. Although wood production is a very important economic activity to the general area, it may conflict with other important forest uses. These other uses include recreation, wildlife habitat, pollution abatement and watershed/erosion management. 
Table 4

ATTAINMENT STATUS DESIGNATIONS FOR STATE OF RHODE ISLAND

\begin{tabular}{|c|c|c|c|c|c|}
\hline $\begin{array}{l}\text { Pollutant and } \\
\text { Designated Area }\end{array}$ & $\begin{array}{l}\text { Does Not Meet } \\
\text { Primary stds }\end{array}$ & $\begin{array}{l}\text { Does Not Meet } \\
\text { Secondary Stds }\end{array}$ & $\begin{array}{l}\text { Cannot Be } \\
\text { Classified }\end{array}$ & $\begin{array}{l}\text { Cannot Be Classified } \\
\text { or Better Than } \\
\text { National Standards }\end{array}$ & $\begin{array}{l}\text { Better Than } \\
\text { National } \\
\text { Standards }\end{array}$ \\
\hline \multicolumn{6}{|l|}{$\begin{array}{l}\text { Total suspended } \\
\text { Particulates }\end{array}$} \\
\hline Providence & $x$ & & & & \\
\hline $\begin{array}{l}\text { East Provi dence } \\
\text { Cranston, Warwick, } \\
\text { Providence, Pawtuc } \\
\text { and Central Falls }\end{array}$ & & & $x$ & & \\
\hline Remainder of state & & & & & $\mathbf{x}$ \\
\hline \multicolumn{6}{|l|}{ Sulfur Dioxide } \\
\hline Statewide & & & & & $\mathbf{x}$ \\
\hline \multicolumn{6}{|l|}{ Carbon Monoxide } \\
\hline Providence & $x$ & & & & \\
\hline Remaincler of State & & & & $\mathrm{x}$ & \\
\hline \multicolumn{6}{|l|}{ ozone } \\
\hline Statewide & $x$ & & . & & \\
\hline \multicolumn{6}{|l|}{ Ni trogen Dioxide } \\
\hline Statewide & & & & $x$ & \\
\hline
\end{tabular}

Source: R. I. Department of Environmental Management 
Another large portion of the study area is in pasture land. The historic use of this land has been for grazing and other agricultural uses. This pasture land is primarily vegetated by several varieties of grasses. The lack of trees and openness of the pasture area makes it attractive to many types of urban land uses. Industrial development seems especially well suited to the pasture land. Urban development is not the only use well suited to the pasture. Recreational use is also compatible to the land. Presently, the pasture is unofficially used by motorcycle trail riders, horseback riders and hikers. Passive uses for the pasture include pollution abatement, erosion control and wildlife habitat.

The last major vegetation type in the study area is brush and shrub growth. This vegetation unit is a plant successional community that follows devegetation. As a result, it is found on the urban fringe, abandoned mined areas and in abandoned pasture areas. The most important use of this vegetation type is for wildlife habitat. The dense underbrush provides dwelling sites for many varieties of wildlife species.

It can be seen that each of the three major vegetation types offer several beneficial uses. Very basically, vegetation anchors the soil and aids in erosion control; it filters and absorbs water runoff and aids in water pollution abatement. Further, vegetation synthesizes carbon dioxide to oxygen and aids in air pollution reduction, 
provides habitat for wildife and supplies a link in the ecological chain, and provides aesthetically pleasing screens and buffers between land uses.

other well known uses of vegetation resources include logging and agriculture.

It is important to identify the needs of the community to help determine the use of the vegetation resources of the site. If managed properly, a proper combination of vegetation resources can be maintained to yield the maximum return of benefits with the least amount of environmental degredation.

\section{Wildife Resources}

Because of the difficulty in assessing wildlife itself, it will be analyzed in terms of the ecosystems on the site. An ecosystem is an unique environment containing its own special composition of plant and animal species. Wildlife species are highly dependant upon and integrated within specific ecosystems as is demonstrated by their links to shelter and food. Ecosystems are related by the interchange of resident species. Together, the plant community and animal community make up the total biological system of the site.

The following section identifies the major ecosystems of the study area and lists wildife species commonly associated with each of the ecosystems.

Pasture and Brush: This ecosystem is the result of 
Figure 13, Vegetation

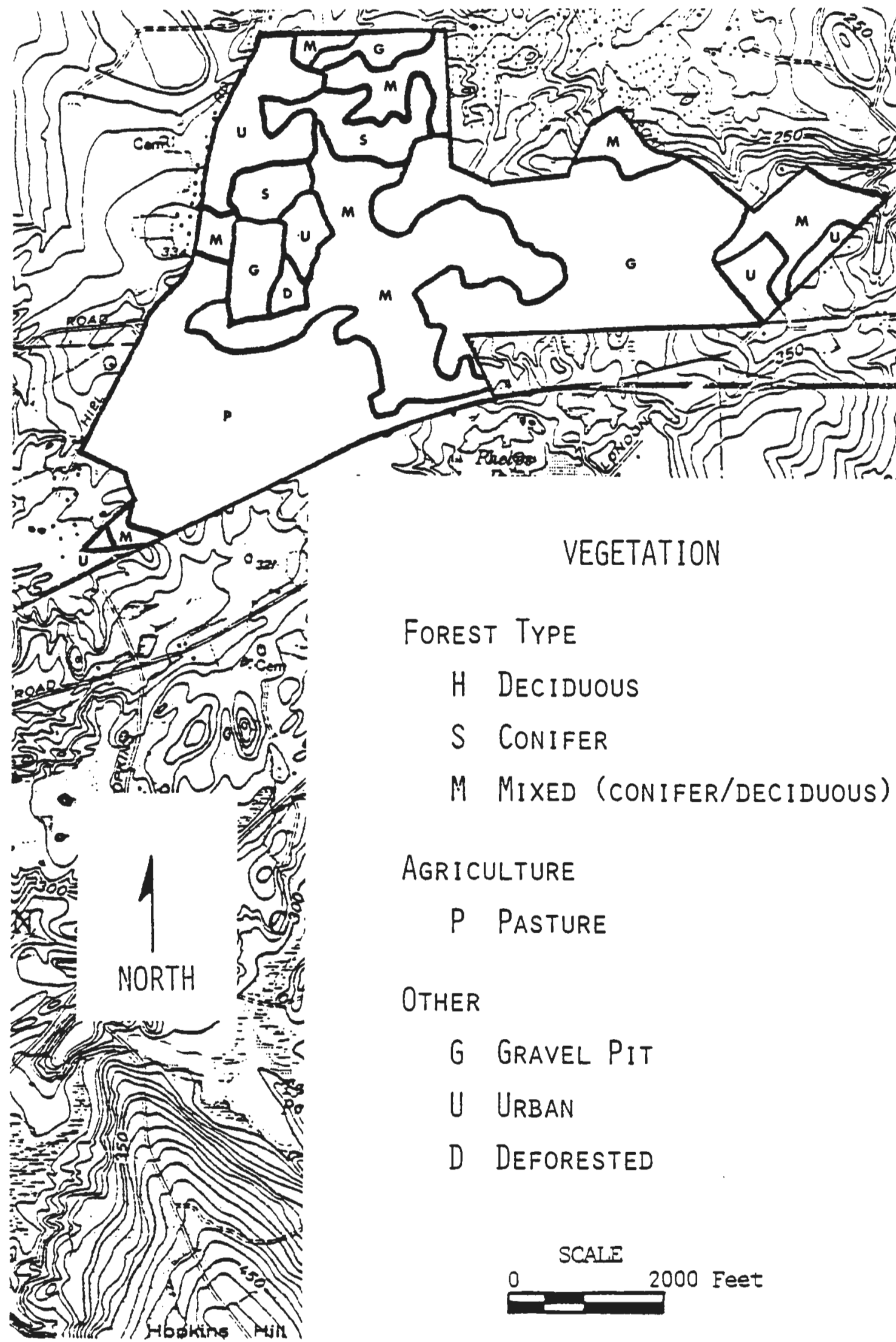


alteration by man. It consists of rolling hills with grassy to successional vegetation. The birds of this ecosystem include the red-winged blackbird, bobolink, eastern meadowlark, bobwhite quail, ring-necked pheasant, field sparrow, song sparrow, morning dove, starling, barn swallow and American goldfinch. Mammals include the meadow mole, racoon, opossum woodchuck, eastern cottontail rabbit, white-footed mouse, meadow jumping mouse and shorttail shrew. Reptiles and amphibians of the site include garter snakes, milk snakes, green snakes, wood turtles, eastern box turtles, various salamanders and tree frogs. ${ }^{13}$

Forest: This ecosystem is mainly vegetated by a mixed forest (conifers and deciduous). Common birds of this ecosystem include the blue jay, crow, black-capped chickadee, tufted titmouse, wood thrush, towhee, black and white warbler, scarlet tanager, ovenbird, yellow-throat warbler and white-breasted nuthatch. Common mammals include the white-footed mouse, redback mole, pine mole, shorttail shrew, eastern chipmunk, red squirrel, southern flying squirrel, red fox, grey fox, racoon, skunk, woodland cottontail rabbit, white-tail deer and short-tailed weasel. Arphibians and reptiles include the black snake, garter snake, milk snake, box turtle, spring peeper, tree frog, spotted and red-backed salamander, American toad and wood frog. 14

Wetland: This ecosystem includes seasonal lacustrine and riverine ecosystems. The actual amount of wetland 
ecosystems on the site is small, but it does contribute to the species diversity of the site. Common birds include the Canada goose, mallard, black duck, wood duck, great blue heron, belted kingfisher, black crowned night heron, red-winged blackbird, American bittern, American coot, greater yellow legs and common egret. Mammals associated with wetland ecosystems include the muskrat, mink, otter, raccoon and star-nosed mole. Herptiles include water snakes, painted and snapping turtles, bullfrogs and leopard frogs. 15

8. Acoustical Analysis

This section will be broken down into three sections. The first section will describe the assumptions and methodology used. It will be followed by a section that will identify existing land uses that may be affected by industrically related noise. The next and last section will present an analysis of the present estimated noise levels of the study area and surrounding areas. Methodology

For this study the design noise standard of $70 \mathrm{~dB}(\mathrm{~A})$ set by the Federal Aid Highway Program will be used. Violation of the standard will be assumed if a noise level of $70 \mathrm{~dB}(\mathrm{~A})$ is exceeded more than 10 percent of the time. This will be called the I 10 noise level.

For the purpose of this study all noise that can be predicted to exceed the I 10 noise level will be mobile. 
Stationary sources that exceed the I 10 standard cannot be predicted at this time, but will be considered nuisances. All stationary nuisances should be dealt with by town regulation. Thus, the areas with the greatest potential to exceed the I 10 noise level will be located nearby highways and interchanges. For this reason, traffic volumes will be the base used to estimate noise levels.

A nomographic method was used to estimate noise levels from the traffic volumes. ${ }^{16}$ It considered vehical speed, traffic composition, and topography. Traffic volumes were determined from three sources. They are: a) Current traffic counts; b) Projected traffic volumes from the Rhode Island Statewide Planning Program (SPP); c) Projected industrial traffic volumes for various levels of industrial development. 17

Four noise enviroment scenarios will be used. They are: a) Year 1979 estimated noise levels; b) Year 2000 estimated noise impact with no industrial development; c) Year 2000 estimated noise impact with limited industrial development; d) Year 2000 estimated noise impact with full industrial development. Each of these scenarios are portrayed on individual maps (Figures 14, 16, 17, 18). The 19.72 estimated noise level is shown in this section and the three futuristic impact scenarios are shown in Chapter IV under Acoustic Impacts. 
Affected Land Uses

The predominant land use surrounding the site is residential. This is also the most sensitive land use to high noise levels. It has already been determined that the major source of excessive noise originates along roads from mobile sources. Thus, most of the residential structures that are impacted by excessive noise are located along major roads.

From Figure 14 it can be seen that the residential structures that are receiving the greatest acoustical impact are located along Hopkins Hill Road, Arnold Road, Route 3, the New London Turnpike and Division Street. Fortunately, only a relatively small number of residential structures are located in areas above the $I 10$ noise level. The two widest paths of excessive noise occur along Route 3 which is predominantly commercial and not subject to the I 10 noise standard and Route I-95 where very little residential development is located. Present Noise Levels

The results of the 1979 estimated noise level analysis are presented in Table 5. The information was determined using a nomograph analysis from 1979 traffic counts. From this analysis it can be seen that half of the sample design points are in areas of acceptable noise levels. Three of the other design points have levels between $70 \mathrm{~dB}(\mathrm{~A})$ and $75 \mathrm{~dB}(\mathrm{~A})$. These are considered to 
Figure 14. ACOUstics; No industrial development, 1979

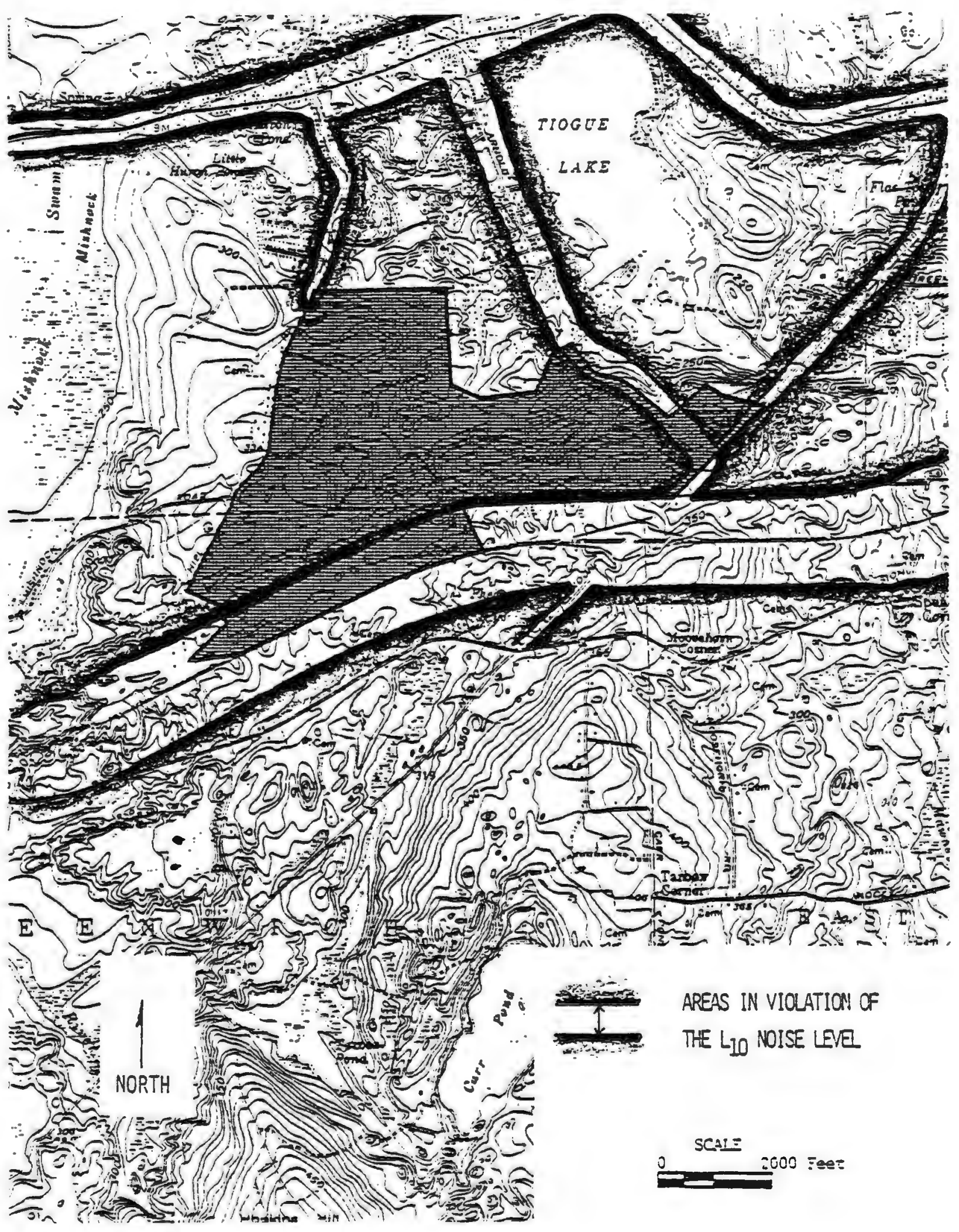


Table $5 \quad 1979$ Noise Analysis

\begin{tabular}{|c|c|c|c|c|c|}
\hline $\begin{array}{l}\text { Design* } \\
\text { Point }\end{array}$ & $\begin{array}{l}\text { Volume } * * \\
\text { dB }(A)\end{array}$ & $\begin{array}{c}\text { Design Hour } \\
\text { Volume } \\
\text { (vehicals) }\end{array}$ & $65 \mathrm{~dB}(\mathrm{~A})$ & $\begin{array}{r}\text { tward } R \\
\text { (Feet } \\
70 \mathrm{~dB}(\mathrm{~A}) \\
\end{array}$ & $\begin{array}{l}\text { ge } \\
(75 \mathrm{~dB}(\mathrm{~A})\end{array}$ \\
\hline 1 & 73 & 770 & 750 & 200 & 75 \\
\hline 2 & 66 & 125 & 140 & 45 & 15 \\
\hline 3 & 65 & 90 & 100 & 30 & 10 \\
\hline 4 & 78 & 2570 & 1000 & 700 & 225 \\
\hline 5 & 73 & 650 & 600 & 175 & 70 \\
\hline 6 & 67 & 165 & 170 & 50 & 17 \\
\hline 7 & 65 & 105 & 110 & 35 & 10 \\
\hline 8 & 71 & 400 & 350 & 125 & 40 \\
\hline $\bar{x}$ & $\overline{69.75}$ & & & & \\
\hline
\end{tabular}

* Design points referenced on Figure 15.

** one hundred feet from source of noise. 
be in violation of the I 10 standard, but impacts may be controlled with proper mitigation proceedures. Only one design point (No. 4) was in excess of the $75 \mathrm{~dB}(\mathrm{~A})$ level. This is the design point located at Route I-95. It has been determined that there is an area extending 225 feet from each side of Route I-95 that exceeds $75 \mathrm{~dB}(\mathrm{~A})$. This area is beyond the level where mitigation proceedures could bring the noise to an acceptable level. 


\section{ACTION AND ALTERNATIVES}

Any industrial development in the study area may cause a variety of environmental impacts, but at this point individual alternatives are not specific enough to discuss or analyze. For this reason only generalized development scenarios can be used. In order to make this and other related studies universal and more useful, development scenarios used by the Statewide Planning Program and the State Department of Transportation will also be used for this study. 18

The basic scenarios are as follows:

I, Full Industrial Development

This assume $100 \%$ site development and 6000 additional employees in the study area, with 4000 employees on the west Greenwich property and 2000 employees on the Coventry property.

II. Limited Industrial Development

This assures $50 \%$ site development and 2000 additional employees in the study area, with 1000 in West Greenwich and 1000 in Coventry.

III. No Industrial Development This assumes a nominal industrial increase as projected by the Statewide Planning Program for the year 2000. This is a total employment of 375 employees; 127 employees for West Greenwich and 248 employees for Coventry. 
The preceeding scenarios will guide the amount of industrial development, but individual development proposals must still be analyzed as they are submitted. This will allow specific impacts to be assessed and the most desirable proposals choosen. 


\section{Chapter IV \\ ENVIRONMENTAI IMPACTS}

1. climate

There will be no significant impact on the local or regional climate resulting from the construction or operation of any permitted industrial operations in the study area.

2. Geology

Approximately 300 acreas (47\%) of the site have already been devoted to sand and gravel surface mining operations on the site. In general, the mining operations have left the affected areas scarred and alterred, bearing little resemblance to the original landscape. Not only do the mining operations cause massive changes in the topography, but soil, water, air, vegetation and wildlife resources will all be affected and alterred as well.

Because of the relative importance of the sand and gravel industry it will not be feasible to stop operations. strict regulations that direct limited operations and enforce restoration procedures will be necessary to avoid adverse impacts to other resources.

\section{Iand Impacts}

Impacts to land resources include impacts to soils, impacts to sand and gravel mining operations and impacts to agriculture and silviculture activities. Each of these impacts is examined below. 
Soils

Construction, devegetation and industrial development on the site will increase the potential for soil losses by erosion. The erosion of soil from the site provides negative impacts both on and off the site. The following section will estimate the extent of the soil erosion and resultant potential impacts.

The Universal Soil Loss Equation was used to determine the potential impact of soil erosion in the study area. ${ }^{19}$ This equation considers rainfall, slope-length, slopegradient and soil erodibility factors for each soil type (soil erodibility factors expressed as $K$, see Table 2). The analysis assumes that soils will be disturbed, unprotected and without soil conservation practices. Surface mined areas already stripped of soil resources will not be considered. Losses estimated are for sheet erosion resulting from rainfall runoff. Large quantities of soil materials that may be lost by rill and gully erosion brought about from heavy runoff concentrations are not included in the estimation.

It is estimated that soil losses will average about 15 cubic yards per acre per year for full industrial development. This is a total of about 9935 cubic yards of soil per year for the entire site. Limited development will also average about 15 cubic yards per acre per year or 4968 cubic yards of soil per year. Some of this eroded 
soil will be moved only a short distance and some will be transported off the site. The resultant impacts include land subsidence, increased water pollution, increased flooding and washouts, changes in local ecology, the filling in of streams, wetlands, lakes, harbors, and bays, and reduced navigation.

\section{Sand and Gravel Mining Operations}

Full industrial development may cause the existing sand and gravel industry located on the site to relocate. It is assumed that this will be less likely with limited industrial development.

Sand and gravel production is becoming increasingly difficult in Rhode Island due to the depletion of available reserves and the difficulty of obtaining new reserves. The difficulty of obtaining new reserves arises due to public opposition, zoning restrictions, local ordinances, and preemptive uses that prohibit sand and gravel mining.

Projections indicate that without new reserves by 2020 , sand and gravel will have to be imported into Phode Island, mined from the sea, or artificially made. 20 These alternatives are likely to result in higher prices and energy use as well as greater environmental costs.

\section{Agriculture}

Development of the site for full industrial use will preclude its use for agricultural or silvicultural activities. Limited industrial development can allow preservation of 
all prime agricultural land.

Abandonment of prime, local farm land may have future impacts of local and regional significance. The benefits of local farms and locally produced food that would be lost or impacted are listed below.

1) Iower food prices

2) Higher self sufficiency and less potential for food shortages

3) Fresh, high quality food

4) Aesthetic assets

5) Promotion of efficient utilization of existing public services and facilities

6) Inhibition of urban sprawl

7) Provision of aesthetic buffers between developments

4. Water Resources Impact

Industrial development in the project area may cause moderate impacts on water resources. Construction operations and site runoff will be the main source of this nonpoint source pollution.

All point source discharges from industry will be removed from the site for treatment in West Warwick via a fifteen inch part gravity flow/part force main sewer line. As a result there will not be any impacts to local waters from point source pollution discharges.

The following section will analyze water quality impacts to ground-water and surface waters resulting from non-point source pollution and construction operations. 


\section{Ground-water}

The large high quality reserves of ground-water resources in the general area have local and regional significance for present and future water supplies. The rapid permeability of soils and surficial materials indicate that pollutants may easily percolate into the groundwater reserves. For this reason special considerations must be given to each type of pollutant found on the site. Particulate matter: This pollutant source includes soil sediments, inorganics leaked or corroded from machinery or building materials, organic matter from litter and food wastes, and other suspended solids. Vegetation and soil acting as a natural filter can remove most of these particles before they reach the water table, thus avoiding substantial impact to ground-water resources.

Hydrocarbons: Oil and grease from roadway runoff and minor spills from machinery can be broken down by bacteria. Further filtration through vegetation and soils will confine hydrocarbon products to the organic soil layer where break down will occur.

Chlorides: This pollutant will result from applications of de-icing agents on roadways and parking lots in winter months. Under no circumstances should uncontrolled amounts of chlorides be allowed to Jeach into the groundwater. 
Surface water

Estimated surface water pollution resulting from industrially related runoff on the site may cause significant downstream impacts on vegetation, wildlife, aesthetics and recreation. It is noted that estimated pollution factors have been derived by the University of Florida from a very limited data base. ?I

Table 6 Surface Water Quality

$\begin{array}{lrrrr}\text { Pollutants } & \begin{array}{c}\text { Existing } \\ \text { development }\end{array} & \begin{array}{c}\text { Limited industrial } \\ \text { development }\end{array} & & \begin{array}{c}\text { Fulj industrial } \\ \text { development }\end{array} \\ \text { BOD } & 1.19 \mathrm{ppm} & 4.82 \mathrm{ppm} & & 8.5 \mathrm{ppm} \\ \text { SS } & 50.74 \mathrm{ppm} & 127.02 \mathrm{ppm} & & 203.3 \mathrm{ppm} \\ \text { PO4 } & .05 \mathrm{ppm} & .27 \mathrm{ppm} & & .49 \mathrm{ppm} \\ \text { N } & .76 \mathrm{ppm} & 1.35 \mathrm{ppm} & & 1.94 \mathrm{ppm} \\ \text { N/PO4 } & 15.2 & 5 & 3.96\end{array}$

It is assumed that the increased level of pollutants may cause significant impacts to Tiogue Iake. It is suggested that field studies be done to confirm all possible impacts.

other types of pollution with the potential to impact surface water resources are road salts, hydrocarbon products and particulate matter. Each of. these will be discussed below.

Road salts: This pollutant must be given special treatment to avoid contaminating soils, surface water bodies and water supply sources. Uncontrolled application of 
road salt will result in water pollution and soil contam ination.

Particulate matter: This pollutant will be highest during construction operations due to soil erosion. Conservation practices should control most temporary and permanent sources of particulate matter.

Hydrocarbons: These will be trapped by vegetation and soils and then be broken down by bacteria. No significant impacts are expected.

\section{Runoff and Discharge}

Increased runoff and discharge is caused by the increased amount of impervious materials used in the watershed. These materials include rooftops, parking lots and roadways. As a result, precipitation is not absorbed by the soils. Runoff and discharge rates will increase causing higher flooding potential to downstream areas.

Table 7 shows the increases in runoff and discharge from present conditions to future conditions with full industrial development. Department of Agriculture, Soil Conservation service methods were used to predict the future values given in Table 7. More detailed calculations than were used in determining these estimates may be found in Appendix B.

The data in Table 7 shows that peak runoff and discharge over project area watersheds as a result of full 
Table 7 Runoff and Discharge Impacts From Full Industrial Development

\begin{tabular}{|c|c|c|c|c|c|}
\hline Storm Event & & $\begin{array}{c}10 \\
\text { year }\end{array}$ & $\begin{array}{c}25 \\
\text { year } \\
\end{array}$ & $\begin{array}{c}50 \\
\text { year } \\
\end{array}$ & $\begin{array}{l}100 \\
\text { year }\end{array}$ \\
\hline $\begin{array}{l}24 \text { Hour rainfall } \\
\text { (inches) }\end{array}$ & & 5.0 & 5.5 & 6.5 & $7.1^{\circ}$ \\
\hline \multirow[t]{2}{*}{ Watershed No. 1} & $\begin{array}{l}\text { Runoff } \\
\text { inches }\end{array}$ & 0 & 0 & 0 & 0 \\
\hline & $\begin{array}{l}\text { Discharge } \\
\text { (cfs) }\end{array}$ & 0 & 0 & 0 & 0 \\
\hline \multirow[t]{2}{*}{ Watershed No. 2} & $\begin{array}{l}\text { Runoff } \\
\text { inches }\end{array}$ & $1.1(858)$ & $1.2(75 \%)$ & $1.3(578)$ & $1.4(528)$ \\
\hline & $\begin{array}{l}\text { Discharge } \\
\text { (cfs) }\end{array}$ & $193(148 \%)$ & $234(135 \%)$ & $298(1118)$ & $350(1048)$ \\
\hline \multirow[t]{2}{*}{ Watershed No. 3} & $\begin{array}{l}\text { Runoff } \\
\text { inches }\end{array}$ & $.7(54 \%)$ & $.8(508)$ & $.9(39 \%)$ & $1.0(37 \%)$ \\
\hline & $\begin{array}{l}\text { Discharge } \\
\text { (cfs) }\end{array}$ & $61(95 \%)$ & $78(89 \%)$ & $102(768)$ & $130(74 \%)$ \\
\hline \multirow[t]{2}{*}{ Watershed No. 4} & $\begin{array}{l}\text { Runoff } \\
\text { inches }\end{array}$ & $.7(548)$ & $.7(44 \%)$ & $.8(35 \%)$ & $.9(33 \%)$ \\
\hline & $\begin{array}{l}\text { Discharge } \\
\text { (cfs) }\end{array}$ & $146(92 \%)$ & $163(180 \%)$ & $217(69 \%)$ & $268(67 \%)$ \\
\hline \multirow[t]{2}{*}{ Watershed No. 5} & $\begin{array}{l}\text { Runoff } \\
\text { inches }\end{array}$ & $1.7(1318)$ & $1.8(113 \%)$ & $2.1(91 \%)$ & $2.2(81 \%)$ \\
\hline & $\begin{array}{l}\text { Discharge } \\
\text { (cfs) }\end{array}$ & $218(2518)$ & $238(222 \%)$ & $294(1928)$ & $317(176 \%)$ \\
\hline
\end{tabular}

Key: Runoff increase caused by industrial development (inches).

Discharge increase caused by industrial development (cfs). 
industrial development will be greatest in watershed 5 and least in watershed 1 . Watersheds 2,3 , and 4 are intermediate in runoff impacts, however, each one drains through urban development to Tiogue Jake and may cause potential flood impacts during severe storms due to undersized road culverts.

\section{Air Resources Impact}

It is not expected that stationary sources of air pollution will have any further impact on air resources. Tight controls set by the state Implementation Plan as authorized by the Federal Clean Air Act will not permit any new major stationary sources of air pollution in Rhode Island. Under the State's New Source Review which has yet to gain legal authority, new sources of air pollution will be allowed only if it is proven that areawide air quality impacts are reduced (see Appendix G) .

Minor increases of air pollutants can be expected from automobiles as a result of the industrial development of the site and increased area urbanization as summarized in Table 8 .

6. Vegetation Impacts

plant communities will be impacted by industrially related development in various ways. The primary impact will be from the direct removal and loss of vegetation growth. Secondary impacts will result from the use of deicing agents, drainage alteration and improper landscaping. These secondary impacts are less pronounced, 


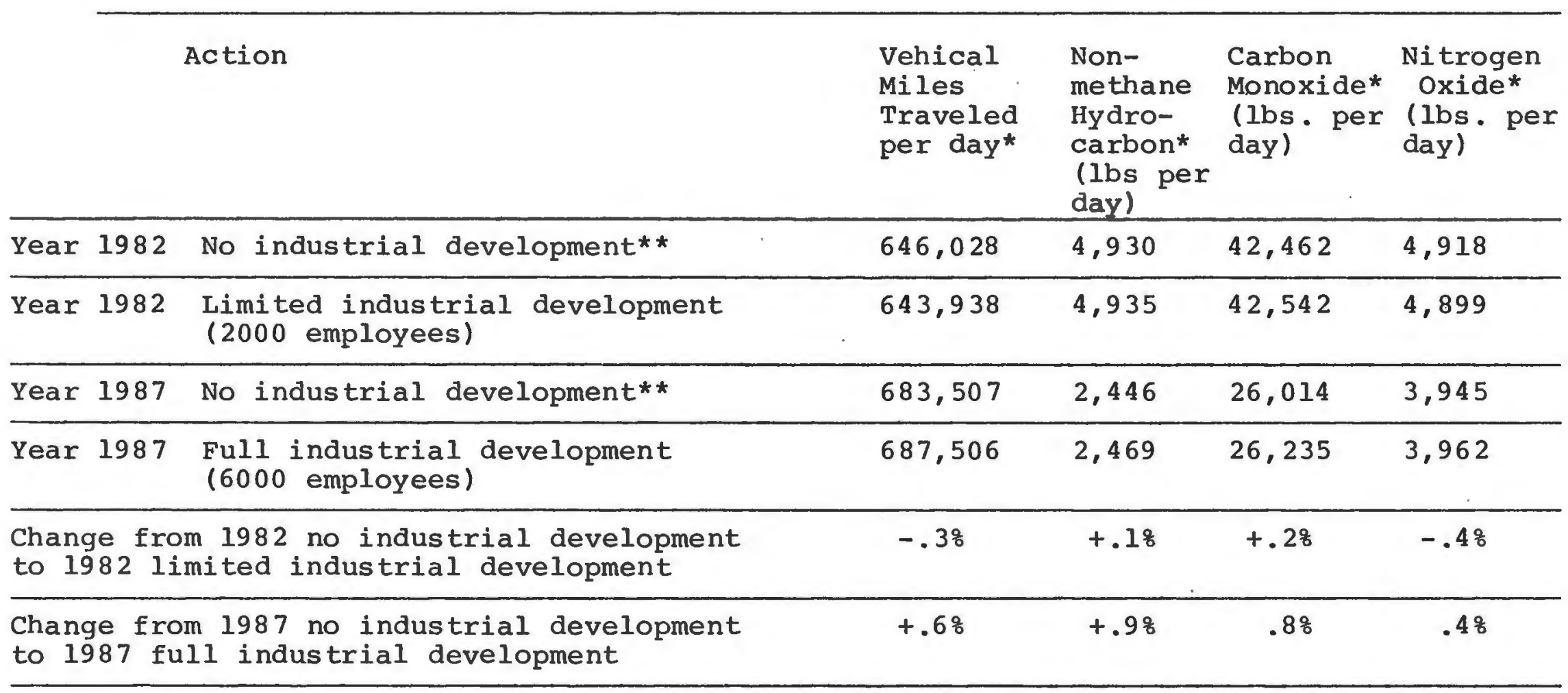

* Data is combined for the towns of Coventry, R.I. and West Greenwich, R.I.

** Also assumes that the Hopkins Hill Road/I-95 Interchange will not be built. 
but are more widespread. They will cause a change in species types, species diversity and total plant production. Overall, the impacts will reduce wildlife, increase air and water pollution, increase erosion and soil losses, decrease recreation opportunities, and limit the future growing potential.

Full industrial growth will have the greatest impact on vegetation resources. Impacts will be most severe to forest and wetland plant communities. These plant communities will not reestablish themselves for many years after alteration. As a result, these special environments and benefits that are now present will be lost. Limited industrial development will. cause minor temporary effects to vegetation resources if located in pasture, brush, and mined out areas. The grasses, shrubs, and brush located in these areas will reestablish themselves naturally in a relatively short period of time after alteration.

7. Wildife Impacts

Impacts to wildife will occur as ecosystems and foodchains are destroyed by industrial development on the site. At present, the wildlife ecology is relatively stable. This indicates a stable food chain and well suited environment for species of the site. This food chain is inherently related to all other food chains and thus becomes a small link. to all biological systems. A break in the chain will have multiple impacts causing a reduction in species diversity and population levels. Ultimately these impacts will affect the human environment. 
It can be assumed that full industrial development will have some effect on all wildiffe of the site. Impacts will be greatest to species of the forest and wetland ecosystems. The difficulty in reestablishing these ecosystems may cause irretrievable losses of forest and wetland wildife. Limited industrial development will cause few effects if developed in nasture, brush and mined out areas. Pasture and brush ecosystem wildife will not be permanently impacted due to the relatively rapid reestablishment of this ecosystem after alteration. 
8. Acoustical Impacts

The impact of acoustics generated by industrially related activities will be analyzed by three futuristic projections previously described in Chapter II, Acoustic Analysis. They are: a) Year 2000 estimated noise impact with no industrial development; b) Year 2000 estimated noise impact with limited industrial develonment; c) Year 2000 estimated noise impact with full industrial development. These scenarios are shown in Figures 16, 17, and 18, and Tables 10, 11, and 12. From this data it can be seen that these areas exceeding the LIO noise standard become slightly larger as industrial development increases. Noise level increases for all scenarios are summarized below in Table 9 .

Table 9 Acoustical summary (dS(A))

\begin{tabular}{|c|c|c|c|c|}
\hline $\begin{array}{l}\text { Design } \\
\text { Point } \\
\end{array}$ & $\begin{array}{l}\text { Year } 1979 \\
\text { Present }\end{array}$ & $\begin{array}{l}\text { Year } 2000 \\
\text { No Indust. }\end{array}$ & $\begin{array}{l}\text { Year } 2000 \\
\text { Limited In. }\end{array}$ & $\begin{array}{l}\text { Year } 2000 \\
\text { Full Indus try }\end{array}$ \\
\hline 1 & 73 & 75 & 75 & 75 \\
\hline 2 & 66 & 71 & 71 & 73 \\
\hline 3 & 65 & 69 & 72 & 76 \\
\hline 4 & 78 & 80 & 80 & 80 \\
\hline 5 & 73 & 74 & 75 & 74 \\
\hline 6 & 67 & 70 & 71 & 69 \\
\hline 7 & 65 & 71 & 71 & 73 \\
\hline 8 & 71 & 73 & 73 & 73 \\
\hline $\bar{x}$ & 69.75 & 72.88 & 73.50 & 74.13 \\
\hline
\end{tabular}


Figure 15. AcOUStical design POINT LOCATIONS

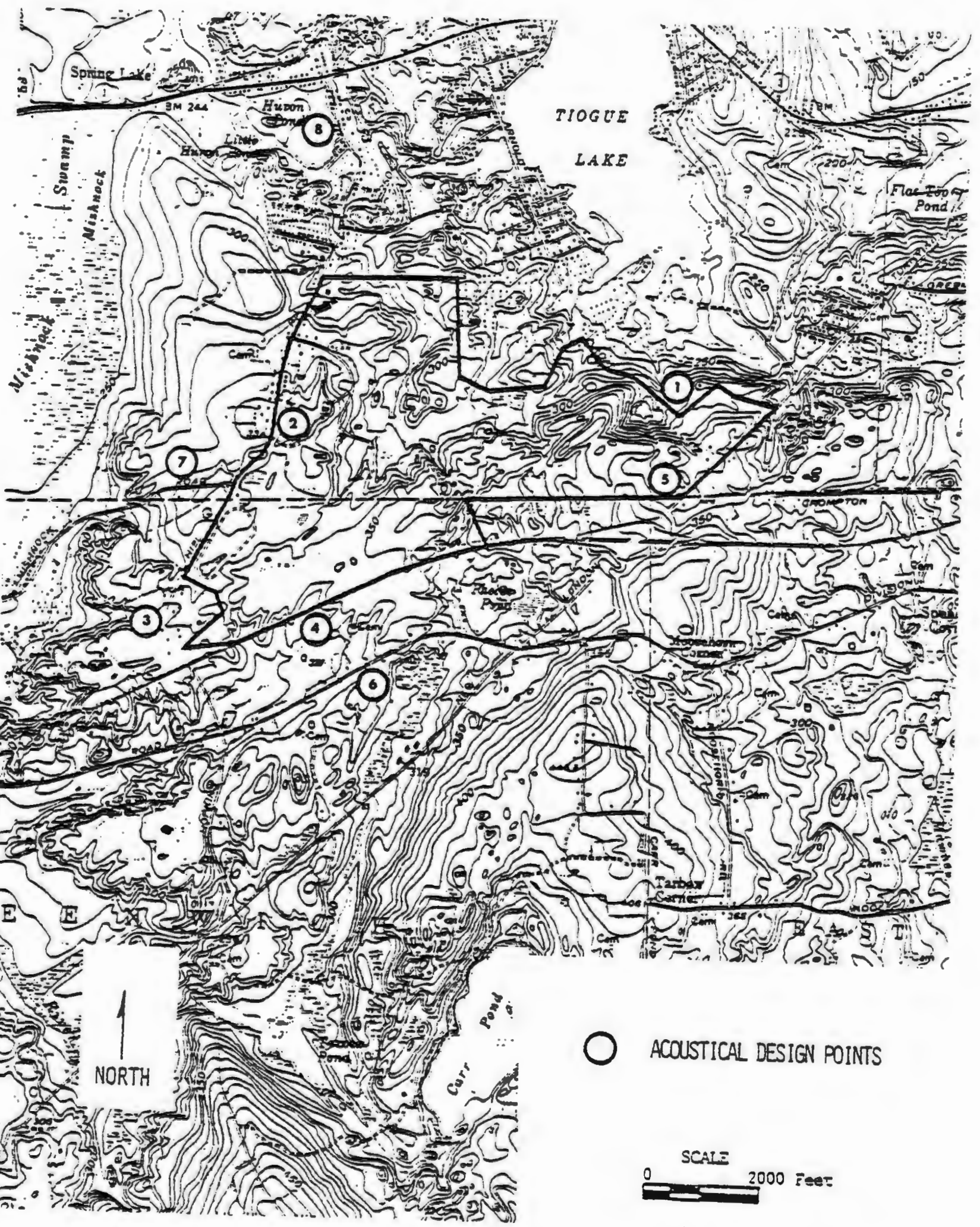


Figure 16. ACOUstics; No industrial Development, 2000

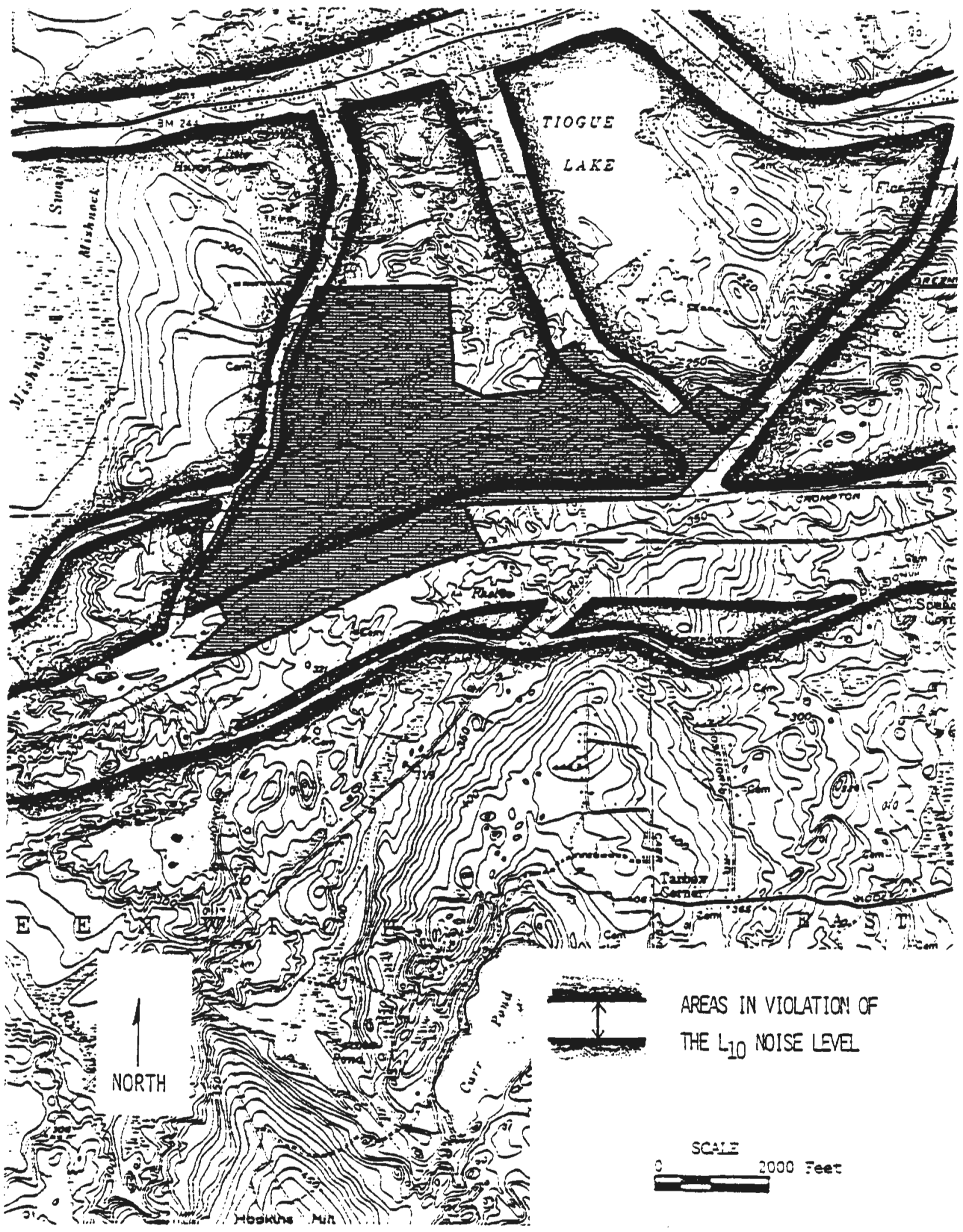




\section{Figure 17. ACOUStics; Limited Industrial DEVELOPMENT, 2000}

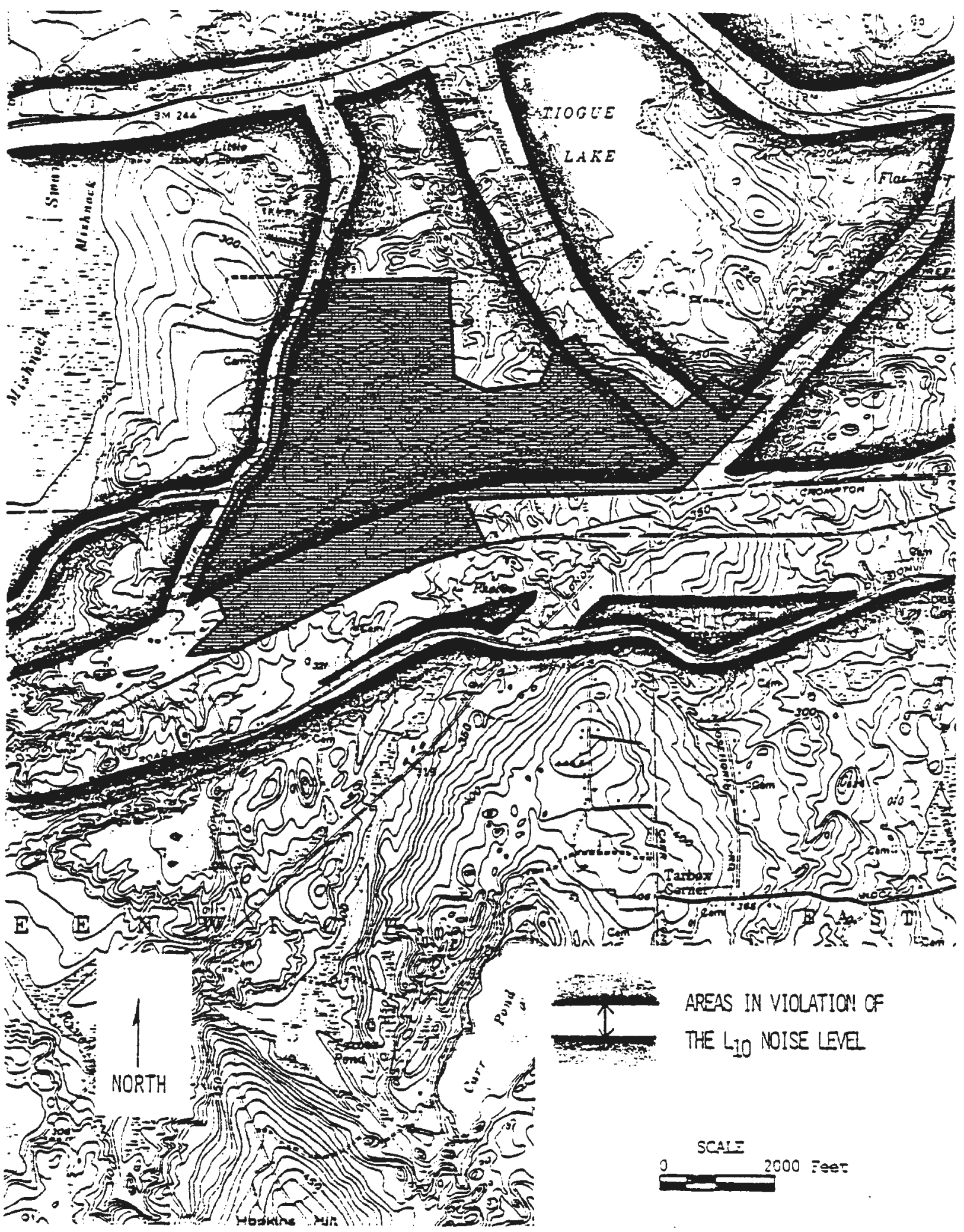


Figure 18. Acoustics; Full industrial development, 2000

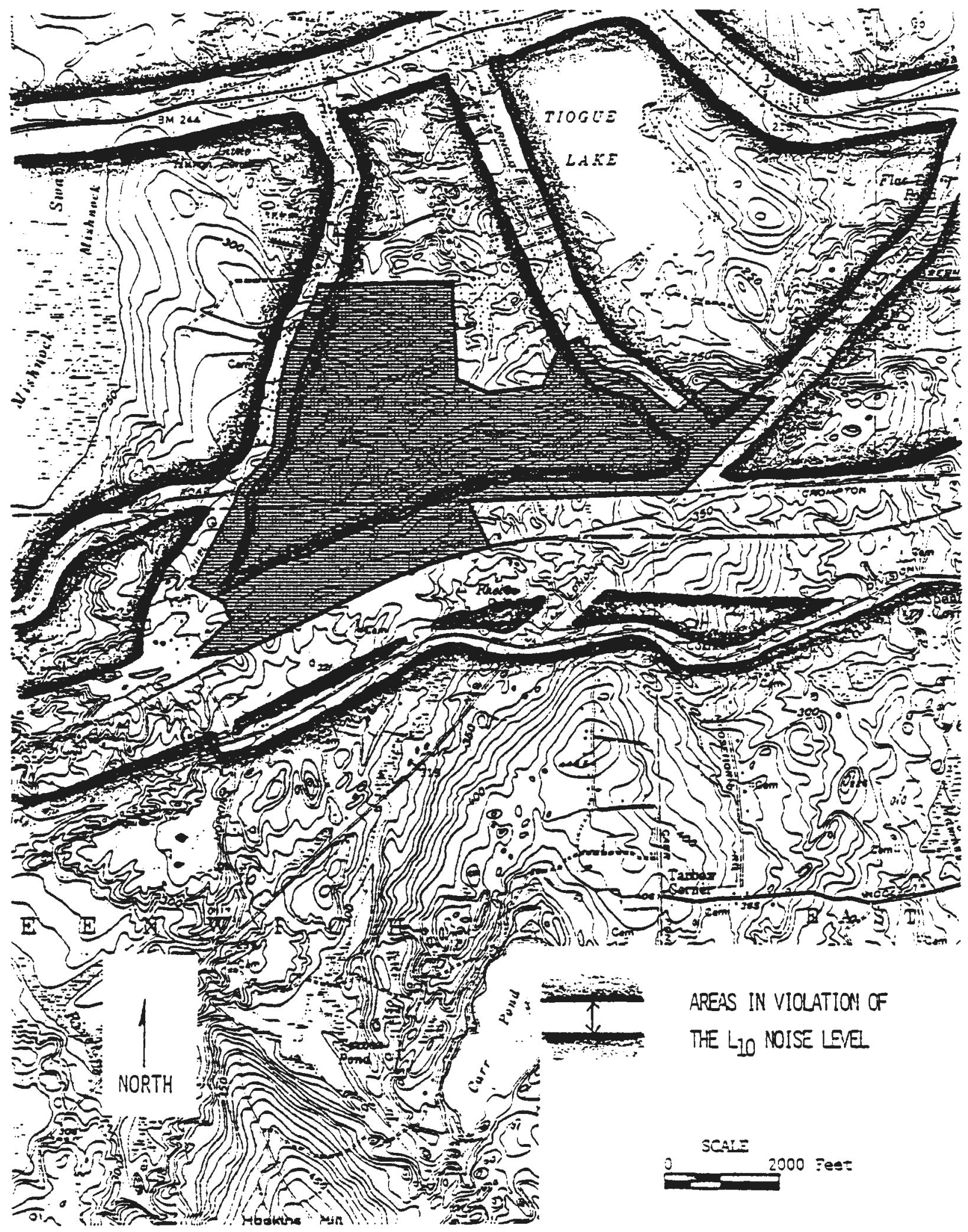


These scenarios will be compared and contrasted in order to isolate the effect of industrial development. Figure 19 illustrates the comparisons that will be made and the average increase in $d B(A)$ from all design points at 100 feet.

Figure 19 Acoustical Comparison ( $\mathrm{dR}(\mathrm{A})$ )

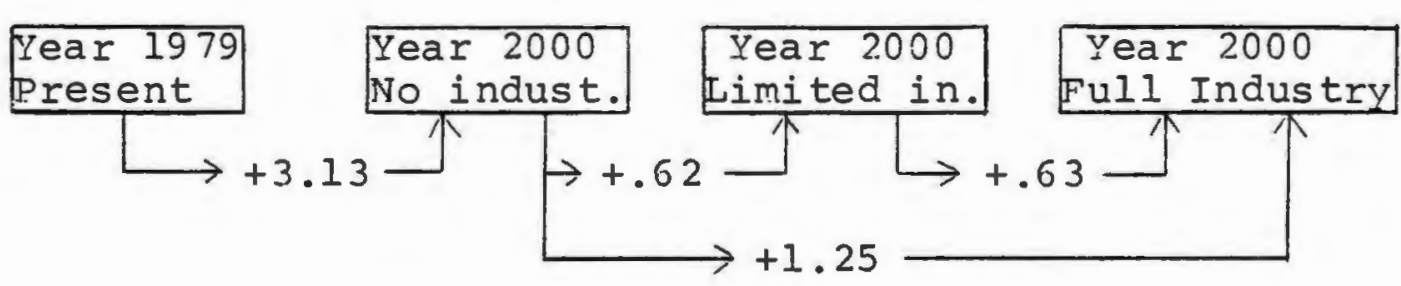

Present to Year 2000 no industrial development

The average change that occurs is an increase of

$3.13 \mathrm{~dB}(\mathrm{~A})$ 's. It will. be very difficult if not impossible to prevent this increase because it has resulted from normal residential development and the continued activities of the area.

Year 2000 no industrial development to limited industrial development

The increase in I 10 sound levels for this comparison is .62. This is a minor increase indicating that a large increase in overall noise levels will not occur. Year 2000 no industrial development to full industrial development

The average change in I 10 noise levels from no to full industrial development will be $1.2 .5 \mathrm{~dB}(\mathrm{~A})$. It can be assumed that this is still not a significant increase for the general area. Although there are at least two areas 
that will have noise levels beyond the range that can be controlled by mitigation, most areas will have insignificant noise increases.

Year 2000 limited industrial development to full industrial development

Although the industrial intensity will triple, the noise level will increase by only $.63 \mathrm{~dB}(\mathrm{~A})$. This can be rationalized by assuming limited industrial development would be local and would use local streets more than full industrial development which would make more exclusive use of Route I-95.

To summarize, one may conclude that normal growth and increased traffic will be the main cause of excess noise by the year 2000. Even as violations of the I 10 noise level occur, $90 \%$ of these violations are still lower than the $75 \mathrm{~dB}(\mathrm{~A})$ level. Industrial development will certainly add to the problem, but if recommended noise abatement procedures are followed many of the resultant noise level impacts can be reduced to acceptable levels. 
Table 10 Projected Year 2000 Noise Impact No Industrial Development

$\begin{array}{lccccc}\begin{array}{l}\text { Design } \\ \text { Point* }\end{array} & \begin{array}{c}\text { Volume** } \\ \text { dB(A) }\end{array} & \begin{array}{c}\text { Design Hour } \\ \text { Volume } \\ \text { (Vehicles) }\end{array} & 65 \mathrm{~dB}(\mathrm{~A}) & \begin{array}{c}\text { Outward Range } \\ \text { (Feet) } \\ 70 \mathrm{~dB}(\mathrm{~A})\end{array} & 75 \mathrm{~dB}(\mathrm{~A}) \\ 1 & 75 & 1075 & 900 & 300 & 100 \\ 2 & 71 & 400 & 350 & 125 & 40 \\ 3 & 69 & 320 & 300 & 95 & 30 \\ 4 & 80 & 3780 & 1000 & 950 & 325 \\ 5 & 74 & 910 & 600 & 240 & 85 \\ 6 & 70 & 300 & 300 & 100 & 35 \\ 7 & 71 & 380 & 340 & 125 & 40 \\ 8 & 73 & 570 & 550 & 175 & 60 \\ \bar{x} & 72.88 & & & & \\ \text { * Design points (see Figure 15) } \\ \text { * * One hundred feet from source of noise. }\end{array}$

Table 11 Projected year 2000 Noise Imnact Limited Industrial Development

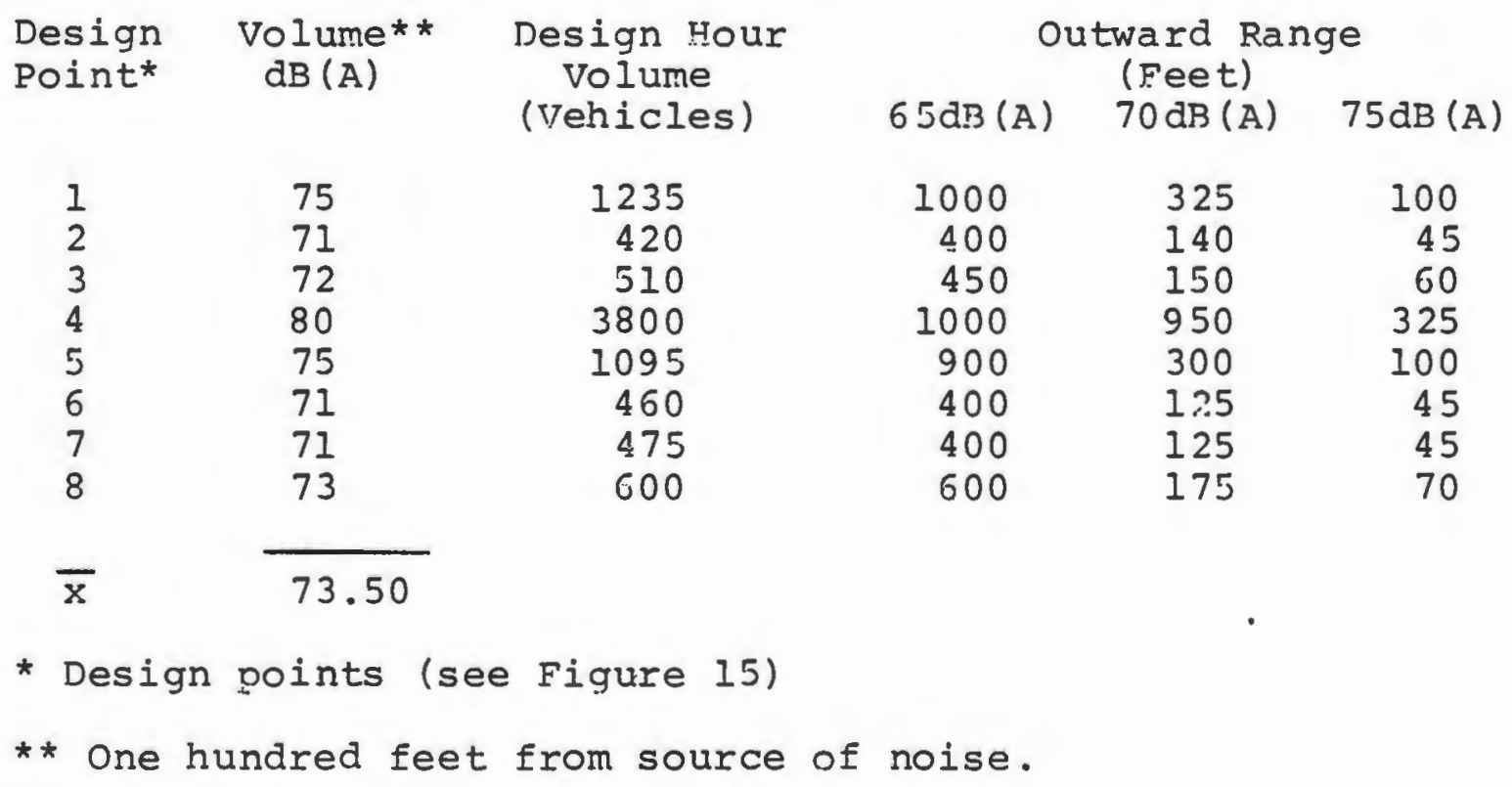


Table 12 Projected year 2000 Noise Impact

Full Industrial Development

\begin{tabular}{|c|c|c|c|c|c|}
\hline \multirow[t]{2}{*}{$\begin{array}{l}\text { Design } \\
\text { Point* }\end{array}$} & \multirow[t]{2}{*}{$\begin{array}{l}\text { Volume** } \\
\text { dB (A) }\end{array}$} & \multirow{2}{*}{$\begin{array}{l}\text { Design frour } \\
\text { Volume } \\
\text { (Vehicles) }\end{array}$} & \multicolumn{3}{|c|}{ Outward Pange } \\
\hline & & & $65 \mathrm{~dB}(\mathrm{~A})$ & $70 \mathrm{dR}(\mathrm{A})$ & $75 \mathrm{dR}(\mathrm{A})$ \\
\hline$I$ & 75 & 1130 & 900 & 300 & 100 \\
\hline 2 & 73 & 805 & 800 & 225 & 80 \\
\hline 3 & 76 & 1600 & 1000 & 425 & 150 \\
\hline 4 & 80 & 4690 & 1000 & 1000 & 400 \\
\hline 5 & 74 & 1030 & 850 & 275 & 95 \\
\hline 6 & 69 & 330 & 300 & 95 & 30 \\
\hline 7 & 73 & 760 & 750 & 200 & 75 \\
\hline 8 & 73 & 725 & 740 & 190 & 70 \\
\hline $\bar{x}$ & 74.13 & & & & \\
\hline * Des & points & e Figure 15) & & & \\
\hline
\end{tabular}




\section{Chapter V}

ADVERSE ENVIRONMFNTAL EFFECTS WNICH CANNOT BE AVOIDED SHOULD INDUSTRIAL DEVELOPMENT BE IMPLEMENTTD

With Full Industrial Development

1. Temporary

a. Some increase of soil erosion during construction.

b. Increased turbidity in surface water from construction operations.

c. Increased levels of dust during construction.

d. Temporary displacements of vegetation and wildlife.

e. Increased noise levels during construction.

2. Permanent

a. Loss of prime agricultural land.

b. Loss of mining industry should new industry preempt mining on the site.

c. Increased surface water runoff.

d. Possible water pollution from road salts.

e. Disturbance of aquifer should uncontrolled mining operations be continued.

f. Decreased recharge to aquifer.

g. Displacement of wildlife and vegetation

h. Minor increase of noise levels from increased traficic.

i. Possible pollution of Tiog̣ue Lake from site runoff. 
With Limited Industrial Development

1. Temporary

a. Some increase of soil erosion during construction.

b. Some increased turbidity in surface water from construction operations.

c. Increased levels of dust durinọ construction

d. Some temporary displacements of vegetation and willitife.

e. Increased noise levels during construction.

\section{Permanent}

a. Possible loss of prime agricultural land.

b. Loss of mining industry should new industry preempt mining on the site.

c. Increased surface water runoff.

d. Possible water pollution from road salts.

e. Disturbance of aquifer should uncontrolled mining operations be continued.

f. Decreased recharge to ađquifer.

g. Some displacement of wildlife and vegetation

h. Minor increase of noise levels from increased traffic.

i. Possible pollution of Tiogue take from site runoff. 
With No Industrial Develonment

1. Permanent

a. Loss of expected employment and economic gains to region.

b. Inefficient utilization of existing facilities and utilities

c. Possible loss of opportunity to restore surface mined areas to productive land. 


\section{Chapter VI}

MEASURES UNDER CONSIDERATION TO MINIMIZE UNAVOIDABLE ENVIRONMENTAL EFFECTS

The following mitigation measures are intended to minimize impacts that may result from the development and construction of industry in the study area. Most of these measures can be implemented by contractual arrangements with developers, but long term protection will require these measures to be added to the town's ordinances. In order to better understand the effectiveness and legal implications of suggested mitigation actions it is suggested that Municipal Environmental Ordinances by Richard Oliver Brooks be reviewed by town planners and other local, officials.

Erosion Control

1. Construction of perimeter dikes to contain sediment and filter runoff.

2. Construction of sediment detention basins.

3. Construction of diversions directing runoff to sediment detention basins.

4. Use of hay bales at the top and toe slopes to trap sediment

5. Use of stone rip rap at critical stream locations.

6. Implementation of temporary and permanent revegetation programs. 
Landuse control

1. Implementation of updated town nolicy for prime agricultural land preservation.

2. Implementation of updated town policy designating the location and extent of desired mining activities.

\section{Runoff and Flood Control}

1. Construction of flood water detention basins.

2. Use of porous materials for roads and parking lots.

3. Construction of roof top and parking lot ponding.

4. Dredging and channeling of streams.

5. Replace inadequate road culverts.

Surface Nater Protection

1. Reduce the amount of salt applied to roads to minimum levels necessary to achieve highway safety.

2. Route runoff through natural vegetation and soil filters.

3. Route high concentrations of runoff nollutants into the Mishnock River Watershed. Large wetland areas located in this watershed will filter out and absorb most pollutants.

4. Limit the amount of impermeable material.s used in watershed 5 to a minimum. 
Aquifer Protection

1. Reduce the amount of salt applied to roads to minimum levels necessary to achieve hioghway safety.

2. Prohibit excessive or deen surface mining operations.

3. Prohibit excavation below the seasonal high water table line.

\section{Air Pollution Control}

1. Use of water to moisten travel lanes on unpaved roads.

2. Implement bus transit, commuter parking, bicycle and carpool/vanpool programs for future site employees.

Vegetation and Wildife Control

1. Use of phased development with complete site restoration to be completed before proceeding to next phase.

2. Maximum preservation of wetland and forest environments.

3. Landscape devegetated areas with an indigenous selection of vegetation.

4. Allow some areas to reestablish vegetation growth naturally. 
Noise Control

1. Route industrial related traffic to avoid imnact on residential development.

2. Improve road surfaces.

3. Provide sound barriers at needed locations

(e.g., walls, vegetation, earth birms). 


\section{Chapter VII}

DEVELOPMENT RECOMMENDATIONS AND THE RELATIONSHIP

BETWEEN LOCA.L SHORT TERM IJSES OF MAN'S ENVIRONMFNT AND MAINTENANCF AND ENHANCEMENT OF LONG TERM PRODUCTIVITY

In order to describe the relationship between local short term uses and long term productivity it is recommended that limited industrial development go forward and all mitigation measures suggested in this report be implemented. It must be understood that a balancing of phased uses will be necessary in order to assure long term productivity of the site.

Zoning will allow a maximum of 25 percent of the site to be structurally developed, thus most of the remaining prime agricultural land, forest land and wetlands may be preserved. The areas presently stripped of soil from mining operations should be landscaped and immediately developed industrially. Controlled and limited mining operations may still extract surficial materials from pasture areas without causing significant impacts to ecological or water resources. Eventually the mining operations must be phased out to assure protection of the underlying aquifer. These areas can then be restored and be used for additional industrial development or open space. Figures 20-24 graphically show how each land use may be phased.

This phased use development will assure optimum use 
Figure 20, Recommended development, phase I
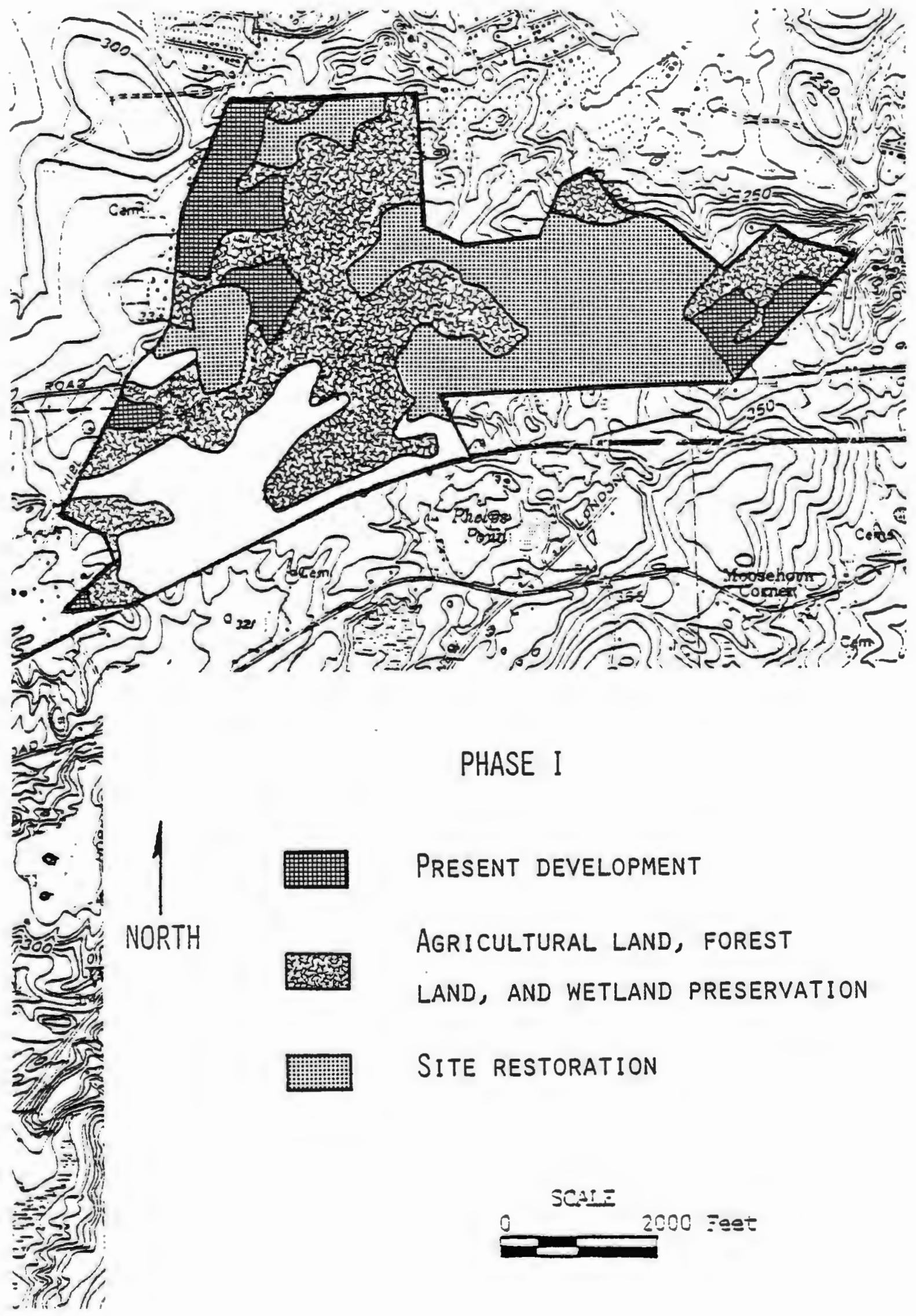

Present DEVELopment

AGRICULTURAL LAND, FOREST

LAND, AND WETLAND PRESERVATION

SITE RESTORATION

$\operatorname{SCA}=$

2000 :9et 
Figure 21. ReCommended deVelopment, phase II

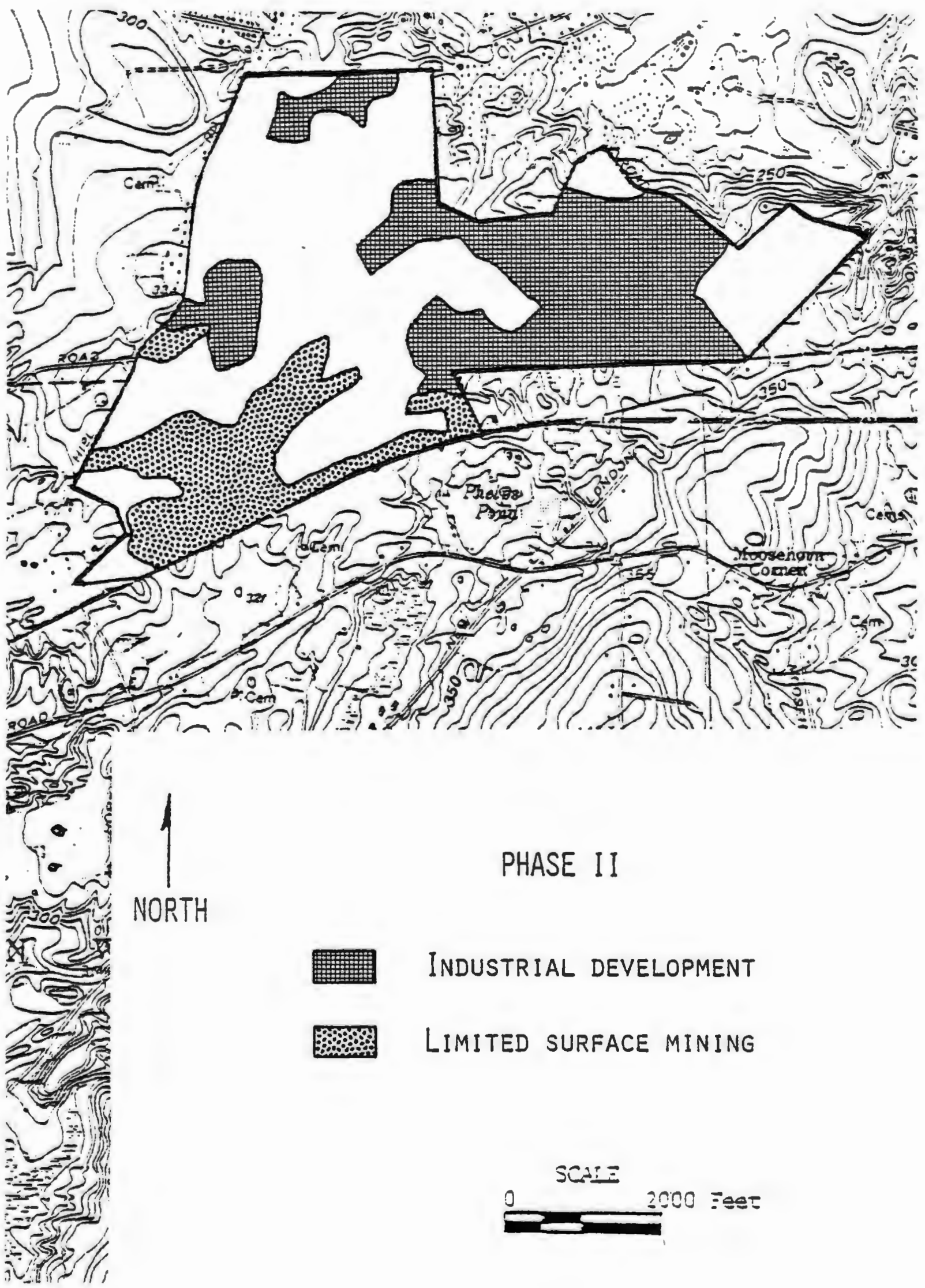


Figure 22. ReCOMmended DEVELOPMENT, PHASE III

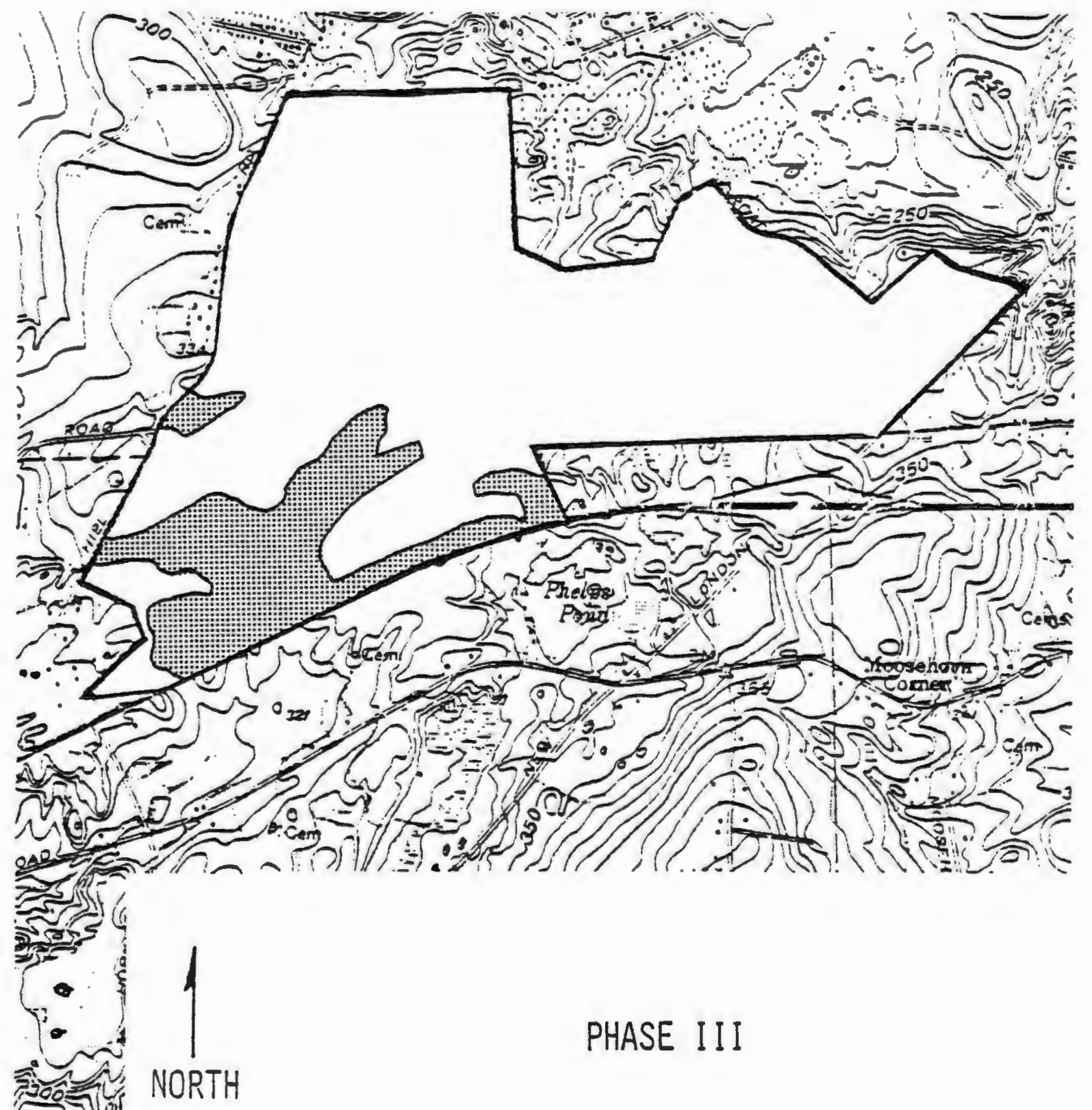

is

SITE RESTORATION
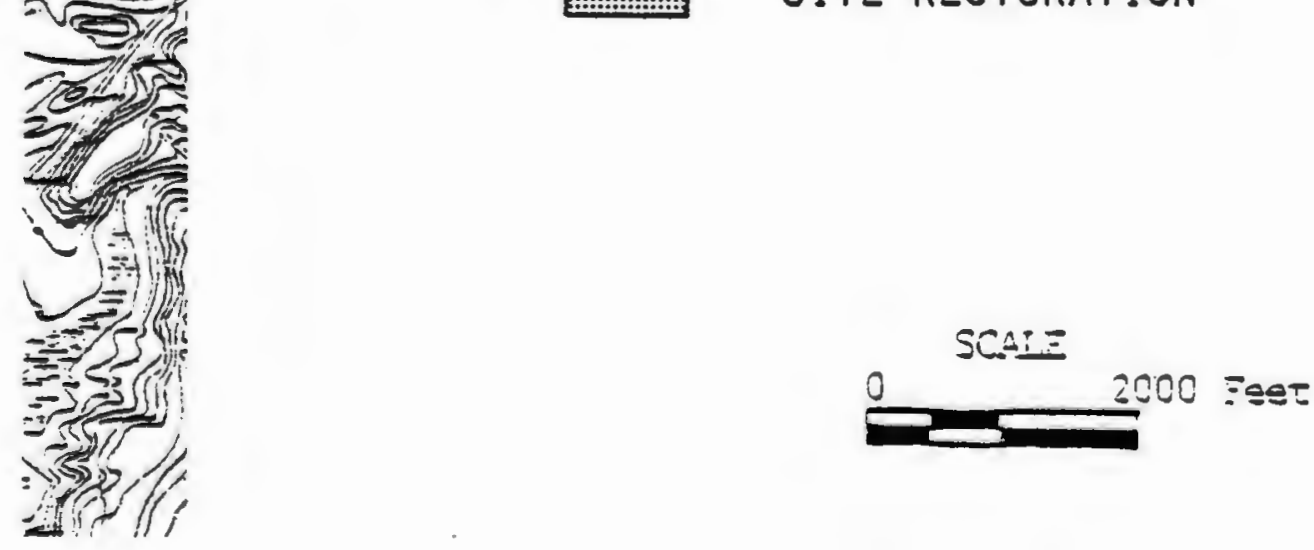
Figure 23. ReCOMMENDEd DEVELopment, PHASE IV
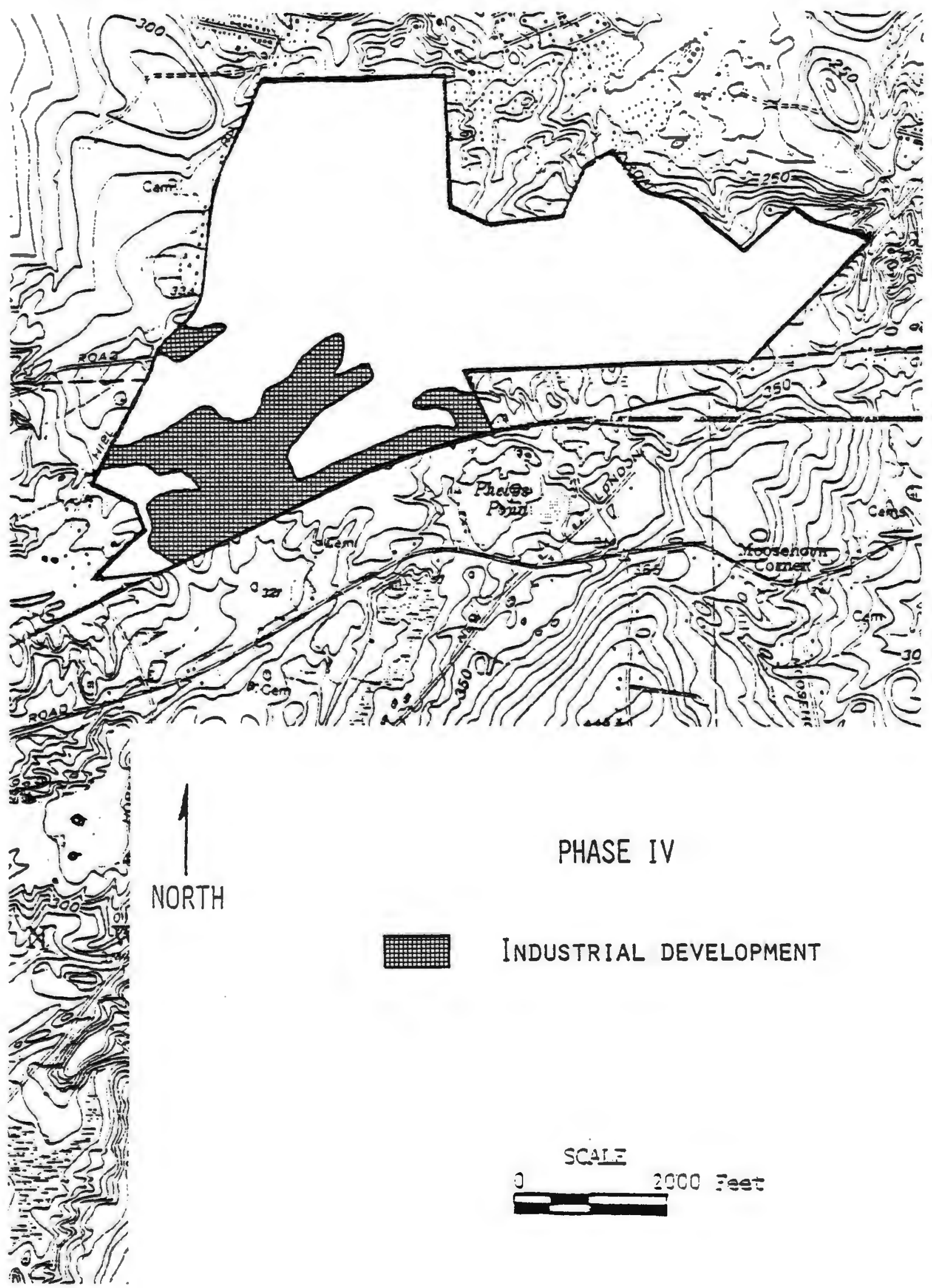

PHASE IV

NORTH

INDUSTRIAL DEVELOPMENT

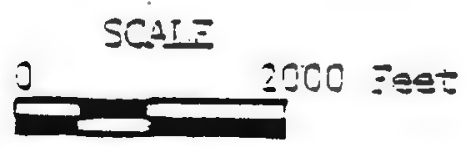


Figure 24. ReCOMMENDED DEVELOPMENT, FinAL

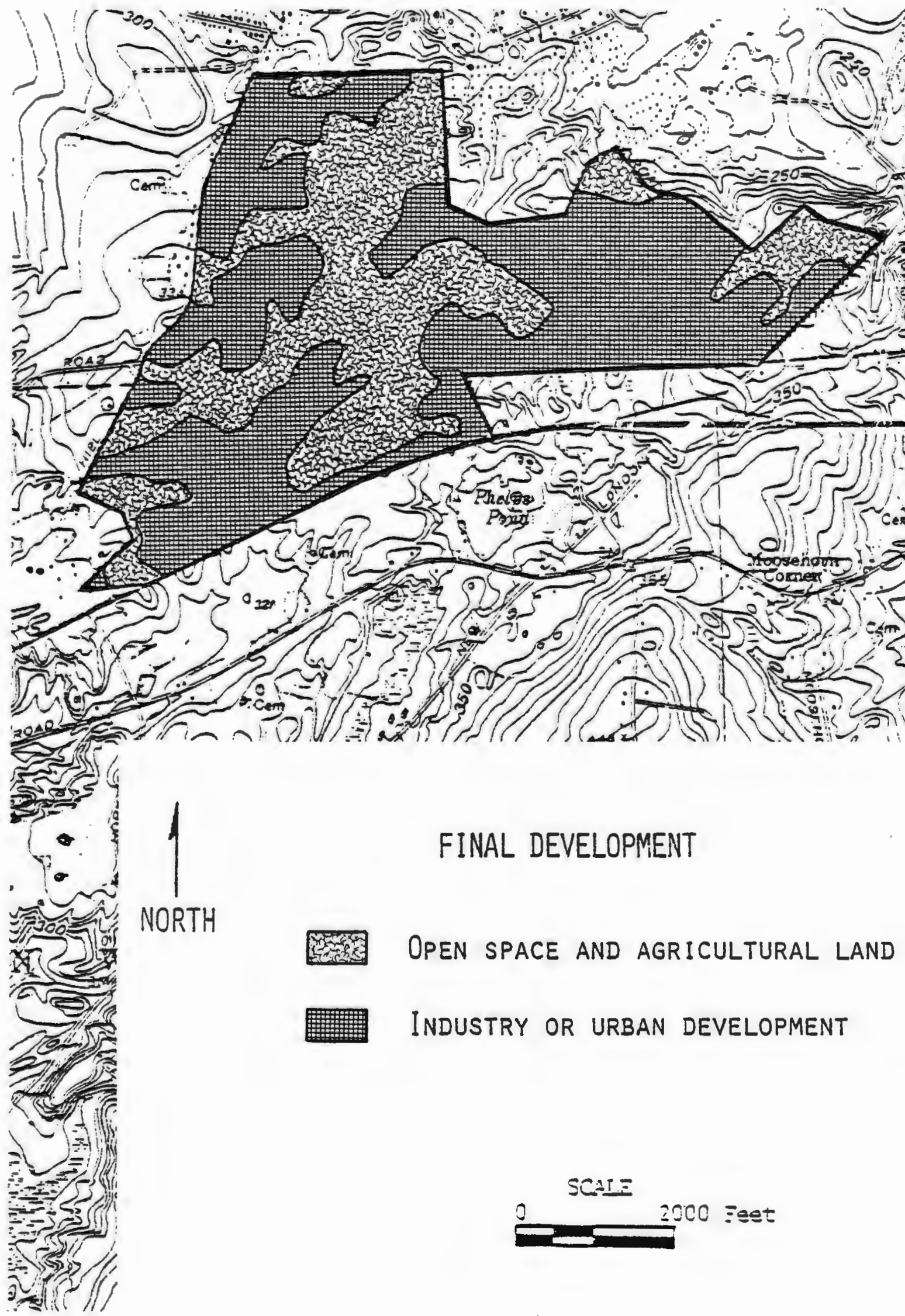


of the site. After balancing and mitigation processes are complete it can be expected that the long term benefits will outweigh any adverse environmental impacts. The high long term productivity of the site can be measured by economic prosperity from industrial development; aquifer and water supply protection; agricultural, wetland and forest land preservation; and limited mineral extraction. This phased use development will prove to be a positive asset and profitable to society on both a regional and local scale. 
Chapter VIII

ANY IRREVERSIBLE AND IRRETRIEVABLE COMMITMENT OF RESOURCES WHICH WOULD BE INVOLVED IN THE RECOMMENDED ACTION, SHOULD IT BE IMPLEMENTED

Irretrievable commitments of natural resources indigenous to the site are limited to deep deposits of sand and gravel not mined for aquifer protection. All other irretrievable commitments will be limited to manpower, building materials, and fuel for construction and operations. 
Appendix A

Coventry Zoning Ordinance

ARTICLE VII INDUSTRIAL PERFORMANCE STANDARDS

Property and buildings to be used for industrial purposes shall be so designed and laid out as to minimize disturbance to adjacent property by such features as buffer fences, planting, suitably located points of traffic ingress and egress, and areas for loading and parking. They shall comply, in addition to the requirements applicable, to the district in which they are located. All industrial operations shall be carried on in conformity with the following requirements:

Section 1. Industrial Performance

1. General

No structure shall be erected for any industrial use, or occupied for industrial use, and no land shall be used for industrial purposes unless industrial use and operation have been certified in accordance with this ordinance. All uses permitted in the I District under Article VI shall conform with this section.

2. Administration of Certification

The Building Inspector shall have the authority to certify a proposed industrial use or operation for probable compliance with Article VII, Section 1.6 of this ordinance. It is recognized that in some cases the Building Inspector cannot adequately judge the relation of a prospective or established industrial use to the performance standards provided in Article VII, Section 1.6 of this ordinance. In such cases, the Building Inspector or the applicant may request an advisory opinion from the Industrial Development Commission Board of Review established under Article VII, Section 2 of this ordinance.

a) Procedure for Certification

Before issuing a building permit for an industrial use, the Building Inspector shall determine whether or not the proposed use will comply with the performance standards in Article VII, section 1.6 of this ordinance. 
b) Plans and Specifications

In order to determine the probable compliance of a proposed industrial use with the performance standards of Article VII, Section 1.6, the Building Inspector may require submission of plans and specifications of any proposed machinery, operations, and techniques to be used to meet the performance standards. No applicant shall be required to reveal any secret processes.

\section{c) Affidavit from Applicant}

The Building Inspector shall require an affidavit from the applicant acknowledging his understanding of the applicable standards provided in Article VII, Section 1.6 and his continuing agreement to comply with these standards.

d) Request for Hearing

Upon filing an application for a building permit for an industrial use, the Building Inspector may require, or the applicant request, a hearing before the Industrial Development Commission Board of Review, conducted according to the provisions of Article VII, Section 1.6 .

3. Review by Industrial Development Commission Board of Review

\section{a) Procedure}

The Industrial Development Commission Board of Review shall review all requests for building permits for industrial use referred to it and make findings as to the probable compliance of the proposed uses to the performance standards of Article VII, section 1.6.

It is intended that the burden of proof for the establishment of reasonable assurance of compliance with performance standards of Article VII, Section 1.6 shall rest with the applicant. No applicant shall be required to reveal any secret processes. The Commission shall invite the applicant or his representative to appear before it at its meeting. 
b) Evidence

The Industrial Development Commission Board of Review may require such evidence as may be pertinent to establishing reasonable assurance that the proposed use will comply with Article VII, Section 1.6 , including expected levels or quantities of smoke, fumes, vibration, liquid or solid wastes, air pollution, gases, heat, and glare or other nuisances as set forth in Article VII, Section 1.6 in terms easily comparable with the values given in that Section.

In cases where correction devices are to be used, they shall be stated and examples of such correction devices in use will be given with such illustrations as are necessary to clearly convey the methods used to the Commission.

Examples of similar industrial operations in actual use with photographs, testimony and explanation, may be submitted to the Commission to clearly convey the type of use and its performance.

4. Issuance of Certificate

Upon determination that a proposed industrial operation complies with Article VII, Section 1.6, certification shall be made by the Building Inspector and shall specify whether certification is granted for conformance in an I District.

5. Enforcement of Standards

a) Violations

In the event of a determination by the Building Inspector of a probable violation of the performance standards subsequent to the granting of a permit, a written notice of the probable violation shall be sent by registered mail to the owner of the industrial use. The notice shall further state that upon the continuation of the probable violation, technical determinations as described in this ordinance shall be made by the Building Inspector and that if violations as alleged are found, costs of such determinations, including the costs of hiring qualified experts, shall be charged against those responsible for the violation, in addition to such 
other penalties as may be appropriate; but that if it is determined that no violation exists, the cost of the determination will be paid by the Town of Coventry.

b) Review by Industrial Development Commission Board of Review

Cases involving probable violations may be referred by the Building Inspector to the Industrial Development Commission Board of Review. In such cases, the Industrial Development Board of Review shall proceed to investigate the alleged violation and shall make such technical determinations as are prescribed in Article VII, Section 1.6 of this ordinance. The Industrial Development Commission Board of Review shall make known its findings in writing to the Building Inspector.

6. Performance Standards

The following standards for the operation of uses in Industrial Districts shall apply:

a) Noise

Noise shall be measured from any property line of the tract on which the manufacturing operation is located. At the specified points of measurement, the sound pressure level of noise radiated continuously from a manufacturing facility or activity (other than background noises not under direct control of the manufacturing use, such as vehicular traffic) shall not exceed the values given in Tables 1 and 2 in octave bands of frequency, between the night-time hours of $11: 00 \mathrm{p} \cdot \mathrm{m}$. and 7:00 a.m.

The instruments used for these measurements shall conform to the specifications published by the American Standards Association, Inc., New York, N.Y. The sound pressure level shall be measured with a Sound Level Meter (American Standard Specifications for Sound Level Meters for measurement of Noise and Other sounds, S1.4-196I) and an Octave Band Filter set, as indicated in Table 1. 
Table 1 MAXIMUM PERMISSIBLE SOUND-PRESSURE LEVELS

$\underline{\text { Pre-1960 Octave Bands }}{ }^{a}$

Octave Band

Frequency

(Cycles per Second)

\section{Decibels}

72

67

59

52

46

40

34

32

Preferred Frequency Octave Bands

Octave Band Center

Frequency

(Cycles per second)

Decibels

76

31.5

63

71

125

250

65

57

500

50

1000

45

2000

39

4000

a Pre-1960 Octave Bands. A standardized series of octave bands prescribed by the American Standards Association in 224!10-1953, Octave Band Filter set for the Analysis of Noise and Other Sounds.

b Preferred Frequency Octave Bands. A standardized series of octave bands prescribed by the American Standards Association in S1.6-1960. Preferred Frequencies for Acoustical Measurements.

If noise is not smooth and continuous and/or is not radiated between the hours of 11:00 P.M. and 7:00 A.M., one or more of the corrections in Table 2 shall be added to, or substracted from, each of the decibel levels given previously in Table 1 . 
Table 2 .

Type of Operation or Character Noise

Correction

Daytime operation 7:00 a.m. to 11:00 p.m. in Decibels

Noise source operated less than $20 \%$ of any one-hour period

plus 5

Noise source operated less than $5 \%$ of any one-hour period

plus $5 *$

Noise source operated less than $1 \%$ of any one-hour period

Noise of impulsive character

(hammering, and so forth)

plus $10 *$

Noise of periodic character

(hum, screech, and so forth)

plus $15 \%$

minus 5

minus 5

*Apply one of these corrections only

b) Vibration

Vibration shall be measured at the nearest property line.

No vibration is permitted which is discernable to human sense of feeling for three minutes or more duration in any one hour of the day between the hours of 7:00 a.m. and $7: 00$ p.m., or 30 seconds or more duration in any one hour between the hours of 7:00 p.m. and $7: 00 \mathrm{a} . \mathrm{m}$. No vibration at any time shall produce an acceleration of more than $0.1 \mathrm{~g}$ or shall result in any combination of amplitudes and frequencies beyond the "safe" range of Table 7, U.S. Bureau of Mines Bulletin No. 442, "Seismic Effects of Quarry Blasting", on any structure. The methods and equations of said Bulletin No. 442 shall be used to compute all values for the enforcement of this regulation.

c) Smoke and Other Forms of Air Pollution

Manufacturing operations shall conform to the "Air Pollution Control Regulations" of the Rhode Island Department of Health, issued under the provisions of Chapter 23-25 of the General Laws of Rhode Island, 1956, as amended, which regulations are hereby incorporated as part of this ordinance. 
d) Sewage and Waste

Effluent from any manufacturing use which is discharged into the ground shall at all times comply with the "Rules and Regulations

Pertaining to Disposal of Sanitary Sewage in

Unsewered Areas" of the Rhode Island Department of Health, issued under the provisions of Chapter 23-1 of the General Laws of Rhode Island, 1956, as amended, which regulations are hereby incorporated as part of this amendment.

e) Heat and Glare

Any manufacturing operation producing heat and/or glare (as differentiated from interior illumination) shall be shielded so that no heat or glare can be recorded at the property line. No lighting shall be used in such a manner that produces glare on public highways or neighboring property.

f) Radiation

Ordinance no longer exists

g) Fly, Ash, Dust, Fumes, Vapors, Gases, and other Forms of Air Pollution

No emission. shall be permitted which can cause any damage to health, to animals or vegetation, or other forms of property or which can cause excessive soiling. In no event shall any emission be allowed of any liquid particles (other than water) in concentrations exceeding 0.3 grains per cubic foot of the conveying gas or air at any point. Measurement shall be taken at the point of emission. For measurement of particles in gases resulting from combustion, standard corrections shall be applied to correct a stack temperature of 500 degrees Fahrenheit and to correct the assumption that 50 percent excess air is present at the time of measurement, which must be deducted from the measured volume ( $0 \%$ excess volume) before computing the grains per cubic foot to compare with the standards.

Standards for individual gases and pollutants shall be as follows: 
Photochemical oxidants - emission of photochemical oxidants shall not exceed a maximum hourly concentration of .04 parts per million, as determined by the Alkaline Potassium Iodine method. 1

Hydrocarbons - the three-hour average concentration of hydrocarbons (with correction for methane) shall not exceed .15 parts per million, as determined by the Flame Ionization Technique.

Carbon Monoxide - the eight-hour average concentration of carbon monoxide shall not exceed 3 parts per million, and the average concentration shall not exceed 20 parts per million in any ninety-minute period, as determined by Continuous Non-Dispersive Infared Analyzers.

Sulfur Oxides - the twenty-four hour average concentration of sulfur oxides shall not exceed .03 parts per million, and the maximum hourly concentration shall be .10 parts per million, as determined by the modified westGaeke Method. 2

Nitrous Oxides - the annual average concentration of nitrous oxides shall not exceed .026 parts per million, as determined by the modified West-Gaeke Method. ${ }^{3}$

Particulate Matter - the twenty-four hour average concentration of particulate matter shall not exceed 100 micrograms per cubic meter, as determined by the High Volume Air Sampling Method.

If monitoring of the ambient air in the Town of Coventry shall determine pollution levels lower than those specified by this ordinance, these lower levels shall be maintained. No significant degradation of air quality shall be permitted within the Town of Coventry.

1 All air sampling methods are those described in Air Quality Criteria, U.S. Department of Health, Education and Welfare, unless otherwise specified.

Scaringelli, S.A.; Saltzman, B.E.; Frey, S.A.; 1967

Saltzman, B.E. 
h) Gases and Fumes

Any gases or fumes emitted in such quantity or of such nature that they are, or potentially may become, odorous or toxic, shall be collected and filtered, washed, absorbed, burned or otherwise treated in a manner approved by the Building Inspector before being discharged into the atmosphere.

Section 2. Industrial Development Commission Board of Review

1. Establishment

An advisory body is hereby established known as the Industrial Development Commission Board of Review. The purpose of this body is to provide technical and scientific assistance in the determination by the Building Inspector of the performance characteristics of proposed or existing industrial operations pursuant to Article VII, section 1.6 of this ordinance.

2. Membership

The Industrial Development Commission Board of Review shall be appointed by the Town Council and shall consist of nine (9) regular members and the Building Inspector who shall serve as an exofficio member. Each regular member shall be appointed for a term of one year respectively. If a vacancy occurs on the Commission, the Town Council shall appoint a new member for the remainder of the unexpired term.

All members of the Commission shall be residents of the Town and no regular member shall be an elected official or an employee of the Town.

3. Chairman

A Chairman shall be elected by the Industrial Development Commission Board of Review.

4. Exemption of Commission Members

No member of the Industrial Development Commission Board of Review shall pass on any matter in which he has a business or personal interest. 
5. Meetings

The Industrial Development Commission Board of Review shall meet monthly and at such other times at the request of the Building Inspector or the Chairman of the Commission.

6. Quorum

Five participating members of the Industrial Development Commission Board of Review shall constitute a quorum. The concurring vote of three members shall be required to pass on any resolution or advisory opinion.

7. Rules and Procedure

The Industrial Development Commission Board of Review shall determine rules of procedure that are not inconsistent with the provisions of this ordinance and existing State and Local Laws. 


\section{West Greenwich Zoning Ordinance}

SECTION 4. Industrial A Zone

The purpose of this zone is to provide areas for the future development of industrial and allied uses and to provide for existing uses of this nature. Areas so designated are considered to be geographically and topographically suitable for such use and are so designated in the interest of providing for the future economic growth of the community.

A. Permitted Uses

1. Manufacture of textile or cloth products from previously prepared textile materials.

2. Manufacture of machine tools, precision instruments, musical instruments, toys and novelties.

3. Manufacture of wood products.

4. Scientific and research laboratories.

5. Manufacture of food products excluding fish, meat, yeast, vinegar, or the rendering or refining of fats and oils.

6. Manufacture, processing and packaging of bakery goods, candy, cosmetics, toiletries, pharmaceuticals or frozen foods.

7. Lumber, coal, building materials, grain and feed storage yards, wholesale and warehouse facilities including cold storage.

8. Freight or trucking terminals.

9. Manufacture of electronic or plastic products.

10. General automotive repair.

11. Auto body and auto body paint shop.

12. Public telephone booths.

13. Signs as permitted in Article III.

14. Parking as required in Article IV.

15. Accessory uses and structures, customarily incident to a permitted use and located on the same lot or site with the principal use. 
B. Uses Authorized as a Special Exception

The following uses shall be subject to review and approval by the Zoning Board of Review:

1. Bulk storage of liquified gas, flammable fluids with flash point below two hundred (200) degrees fahrenheit or other materials representing a potential fire or explosive hazard, not including the storage of fuels in connection with the heating or air conditioning of the structure or structures.

2. Public utility structures.

3. Manufacture of food products from meat, fish, vinegar or yeast.

C. Dimensional Regulations

\begin{tabular}{|c|c|c|c|c|c|}
\hline $\begin{array}{l}\text { Minimum } \\
\text { Lot } \\
\text { Size }\end{array}$ & $\begin{array}{l}\text { Maximum Lot } \\
\text { Coverage by } \\
\text { Structure }\end{array}$ & $\begin{array}{l}\text { Minimum } \\
\text { Front } \\
\text { (depth) }\end{array}$ & $\begin{array}{l}\text { Yard Req } \\
\text { Side } \\
\text { (width) }\end{array}$ & 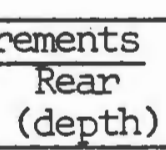 & $\begin{array}{l}\text { Maximum } \\
\text { Building } \\
\text { Height }\end{array}$ \\
\hline res & $25 \%$ & $50 \mathrm{ft}$. & $30 \mathrm{ft}$. & $40 \mathrm{ft}$. & $40 \mathrm{ft} . *$ \\
\hline
\end{tabular}

*The maximum height of the main structure may exceed 40 feet if it is set back from lot lines one additional foot for each foot of height in excess of 40 feet.

No industrial structure shall be closer than one hundred (100) feet to a Rural, Farming, Residential Zone Boundary and no closer than fifty (50) feet to a Neighborhood or Highway Business Zone. 
Appendix B

\section{Runoff Calculations \\ Present Conditions}

Upper Mishnock River Watershed (Number 1)

\begin{tabular}{|c|c|c|c|c|}
\hline $\begin{array}{l}\text { Hydro logic } \\
\text { Soil Type } \\
\end{array}$ & Land Use & $\begin{array}{l}\text { Runoff Curve } \\
\text { Number (RCN) } \\
\end{array}$ & $\begin{array}{l}\text { Area } \\
\text { (acres) }\end{array}$ & $\begin{array}{l}\mathrm{RCN} \\
\text { Area } \\
\end{array}$ \\
\hline A & Forest & 25 & 285 & 7125 \\
\hline $\mathrm{A}$ & Industrial & 81 & 20 & 1620 \\
\hline A & Pasture & 39 & 50 & 1950 \\
\hline$A$ & Residential & 61 & 84 & 5124 \\
\hline B & Forest & 55 & 83 & 4565 \\
\hline B & Industrial & 88 & 5 & 440 \\
\hline B & Pasture & 61 & 5 & 305 \\
\hline B & Residential & 75 & 46 & 3450 \\
\hline C & Forest & 70 & 142 & 9940 \\
\hline C & Meadow & 71 & 66 & 4686 \\
\hline D & Forest & 77 & 50 & 3850 \\
\hline \multirow[t]{5}{*}{ D } & Meadow & 78 & 175 & 13650 \\
\hline & Ouarry & 62 & 20 & 1240 \\
\hline & Roads & 98 & 20 & 1960 \\
\hline & Dirt Roads & 72 & 5 & 360 \\
\hline & & Totals & 1,056 & 60,265 \\
\hline
\end{tabular}

Weighted $\mathrm{RCN}=\frac{\text { total } \mathrm{RCN} \text { * Area }}{\text { total area }}=\frac{60,265}{1,050}=57$

A weighted RCN of 60 will be used.

\section{$\underline{\text { Runoff }}$}

Storm Event 24 Hour Rainfall (inches)

10 year

25 year

50 year

100 year
5.0

5.5

6.5

7.1
1. 3

1.6

2.3

2.7 
Runoff Calculations

Future Industrial Development

Upper Mishnock River Watershed (Number 1)

\begin{tabular}{|c|c|c|c|c|}
\hline $\begin{array}{l}\text { Hydrologic } \\
\text { Soil Type }\end{array}$ & Land Use & $\begin{array}{l}\text { Runoff Curve } \\
\text { Number (RCN) } \\
\end{array}$ & $\begin{array}{c}\text { Area } \\
\text { (acres) }\end{array}$ & $\begin{array}{l}\mathrm{RCN}^{*} \\
\text { Area } \\
\end{array}$ \\
\hline A & Forest & 25 & 265 & 6625 \\
\hline A & Industrial & 81 & 40 & 3240 \\
\hline A & Pasture & 39 & 50 & 1950 \\
\hline A & Residential & 61 & 84 & 5124 \\
\hline B & Forest & 55 & 83 & 4565 \\
\hline $\mathrm{B}$ & Industrial & 88 & 5 & 440 \\
\hline$B$ & Pasture & 61 & 5 & 305 \\
\hline$B$ & Residential & 75 & 46 & 3450 \\
\hline C & Forest & 70 & 142 & 9940 \\
\hline C & Meadow & 71 & 66 & 4686 \\
\hline \multirow{6}{*}{$\begin{array}{l}D \\
D\end{array}$} & Forest & 77 & 50 & 3850 \\
\hline & Meadow & 78 & 175 & 13650 \\
\hline & Suarry & 62 & 20 & 1240 \\
\hline & Roads & 98 & 20 & 1960 \\
\hline & Dirt Roacs & 72 & 5 & 360 \\
\hline & & Totals &, 056 & 51,385 \\
\hline
\end{tabular}

Weighted $\mathrm{RCN}=\frac{\text { total } \mathrm{RCN} \text { *area }}{\text { total area }}=\frac{61,385}{1,056}=58$

Runoff conditions remain the same as in present condi tions. 
Discharge

Upper Mishnock River Watershed (Number 1)

Area: 1056 acres

Slope: $3 \%$

Adjustment factors:

Slope adjustment: 89

Watershed slope adjustment: 1.62

Ponding adjustment:

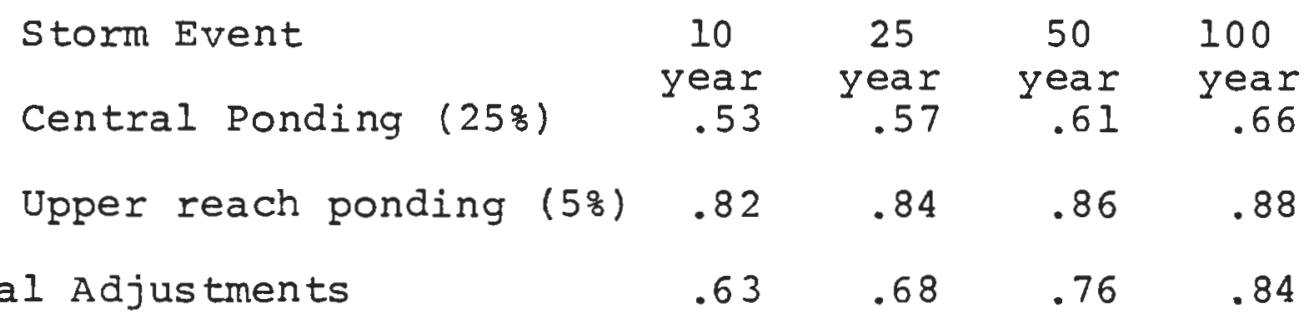

$\begin{array}{lllll}\text { Total Adjustments } & .63 & .68 & .76 & .84\end{array}$

Discharge for Present Conditions and Industrial Development

\begin{tabular}{|c|c|c|c|c|}
\hline storm event & $\begin{array}{c}\text { Runoff } \\
\text { (Inches) } \\
\end{array}$ & $\begin{array}{l}\text { Runoff } \\
(\mathrm{cfs} / I n .) \\
\end{array}$ & Adjustments & $\begin{array}{c}\text { Discharge } \\
\text { (cfs) }\end{array}$ \\
\hline 10 year & 1.3 & 185 & .63 & 152 \\
\hline 25 year & 1.6 & 185 & .68 & 201 \\
\hline 50 year & 2.3 & 185 & .76 & 323 \\
\hline 100 year & 2.7 & 185 & .84 & 420 \\
\hline
\end{tabular}




\section{Runoff Calculations \\ Present Conditions}

\begin{tabular}{|c|c|c|c|c|c|}
\hline $\begin{array}{l}\text { Hydrologic } \\
\text { Soil Type } \\
\end{array}$ & Land Use & $\begin{array}{l}\text { Runoff } \\
\text { Number } \\
\end{array}$ & $\begin{array}{l}\text { Curve } \\
(\mathrm{RCN}) \\
\end{array}$ & $\begin{array}{l}\text { Area } \\
\text { (acres) } \\
\end{array}$ & $\begin{array}{l}\mathrm{RCN} * \\
\text { Area }\end{array}$ \\
\hline A & Forest & 25 & & 117 & 2925 \\
\hline A & Industrial & 81 & & 30 & 2430 \\
\hline A & Openspace & 49 & & 20 & 980 \\
\hline A & Pasture & 39 & & 93 & 3627 \\
\hline$A$ & Residential & 61 & & 116 & 7076 \\
\hline B & Residential & 75 & & 5 & 375 \\
\hline C & Forest & 70 & & 30 & 2100 \\
\hline C & Pasture & 74 & & 10 & 740 \\
\hline C & Residential & 83 & & 5 & 415 \\
\hline$D$ & Forest & 77 & & 15 & 1155 \\
\hline \multirow[t]{5}{*}{ D } & Pasture & 80 & & 30 & 2400 \\
\hline & Quarry & 62 & & 60 & 3720 \\
\hline & Roads & 98 & & 10 & 980 \\
\hline & Dirt Roads & 82 & & 9 & 738 \\
\hline & & To & tals & 550 & 9,661 \\
\hline
\end{tabular}

Weighted $\mathrm{RCN}=\frac{\text { total } \mathrm{RCN} * \text { Area }}{\text { total area }}=\frac{29661}{550}=54$

A weighted RCN of 60 will be used.

\section{Runoff}

Storm Event 24 Hour Rainfall (inches)

10 year

25 year

50 year

100 year
5.0

5.5

6.5

7.1
1.3

1.6

2. 3

2. 7 


\section{Runoff Calculation}

Future Industrial Development

Unnamed watershed Number 2

\begin{tabular}{|c|c|c|c|c|}
\hline $\begin{array}{l}\text { Hydrologic } \\
\text { Soil Type } \\
\end{array}$ & Land Use & $\begin{array}{l}\text { Runoff Curve } \\
\text { Number (RCN) }\end{array}$ & $\begin{array}{c}\text { Area } \\
\text { (acres) }\end{array}$ & $\begin{array}{l}\mathrm{RCN} * \\
\text { Area }\end{array}$ \\
\hline A & Forest & 25 & 17 & 425 \\
\hline A & Industrial & 81 & 219 & 17739 \\
\hline A & Pasture & 39 & 33 & 1287 \\
\hline A & Residential & 61 & 116 & 7076 \\
\hline B & Residential & 75 & 5 & 375 \\
\hline c & Forest & 70 & 10 & 700 \\
\hline C & Industrial & 91 & 30 & 2.730 \\
\hline C & Residential & 83 & 5 & 415 \\
\hline D & Industrial & 93 & 40 & 3720 \\
\hline \multirow[t]{5}{*}{ D } & Pasture & 80 & 5 & 400 \\
\hline & Industrial & 81 & 60 & 4860 \\
\hline & Ouarry Devel & opment & & \\
\hline & Roads & 98 & 10 & 980 \\
\hline & & Totals & 550 & 40,707 \\
\hline
\end{tabular}

Weighted $\mathrm{RCN}=\frac{\text { total } \mathrm{RCN} * \text { Area }}{\text { total area }}=\frac{40707}{550}=74$

\section{Punoff}

Storm Event

10 year

25 year

50 year

100 year
24 Hour Rainfall (inches)

5.0

5.5

6.5

7.1
Runoff (inches)

2.4

2.8

3.6

4.1 


\section{Discharge}

Unnamed Watershed Number 2

Area: 550 acres

Slope: 6 \%

Adjustment factors:

Slope adjustment: 1.16

Watershed slope adjustment: 1.22

Ponding adjustment:

$\begin{array}{lcccc}\text { Storm Event } & 10 & 25 & 50 & 100 \\ & \text { year } & \text { year } & \text { year } & \text { year } \\ \text { Central Ponding (28) } & .81 & .83 & .85 & .87 \\ \text { Design Point Ponding (38) } & .67 & .71 & .75 & .78 \\ \text { l Adjustments } & .77 & .83 & .90 & .96\end{array}$

Total Adjustments

Discharge for Present Conditions

\begin{tabular}{|c|c|c|c|c|}
\hline Storm event & $\begin{array}{c}\text { Runoff } \\
\text { (Inches) }\end{array}$ & $\begin{array}{c}\text { Runoff } \\
\text { (cfs/In.) }\end{array}$ & Adjustments & $\begin{array}{l}\text { Discharge } \\
\text { (cfs) }\end{array}$ \\
\hline 10 year & 1.3 & 130 & .77 & 130 \\
\hline 25 year & 1.6 & 130 & .83 & 173 \\
\hline 50 year & 2.3 & 130 & .90 & 269 \\
\hline 100 year & 2.7 & 130 & .96 & 337 \\
\hline
\end{tabular}

Discharge for Future Industrial Development

\begin{tabular}{|c|c|c|c|c|}
\hline Storm event & $\begin{array}{c}\text { Runoff } \\
\text { (Inches) }\end{array}$ & $\begin{array}{l}\text { Runoff } \\
(\mathrm{cfs} / \mathrm{In} .)\end{array}$ & Adjustments & $\begin{array}{c}\text { Discharge } \\
\text { (cfs) }\end{array}$ \\
\hline 10 year & 2.4 & 175 & .77 & 323 \\
\hline 25 year & 2.8 & 175 & .83 & 407 \\
\hline 50 year & 3.6 & 175 & .90 & 567 \\
\hline 100 year & 4.1 & 175 & .96 & 689 \\
\hline
\end{tabular}




\section{Runoff Calculations \\ Present Conditions}

\begin{tabular}{|c|c|c|c|c|}
\hline $\begin{array}{l}\text { Hydrologic } \\
\text { Soil Type } \\
\end{array}$ & Land Use & $\begin{array}{l}\text { Runoff Curve } \\
\text { Number (RCN) }\end{array}$ & $\begin{array}{l}\text { Area } \\
\text { (acres) }\end{array}$ & $\begin{array}{l}\text { RCN* } \\
\text { Area }\end{array}$ \\
\hline $\begin{array}{l}\mathrm{A} \\
\mathrm{A} \\
\mathrm{A}\end{array}$ & $\begin{array}{l}\text { Forest } \\
\text { Openspace } \\
\text { Residential }\end{array}$ & $\begin{array}{l}25 \\
49 \\
61\end{array}$ & $\begin{array}{r}50 \\
8 \\
50\end{array}$ & $\begin{array}{r}1250 \\
392 \\
3050\end{array}$ \\
\hline $\begin{array}{l}\text { B } \\
\text { B }\end{array}$ & $\begin{array}{l}\text { Forest } \\
\text { Residential }\end{array}$ & $\begin{array}{l}55 \\
75\end{array}$ & $\begin{array}{r}5 \\
15\end{array}$ & $\begin{array}{r}275 \\
1125\end{array}$ \\
\hline \multirow[t]{4}{*}{ C } & Forest & 70 & 8 & 560 \\
\hline & Quarry & 62 & 103 & 6386 \\
\hline & & Totals & 239 & 13,038 \\
\hline & Weighted RCN & $=\frac{\text { total } \mathrm{RCN}^{*} \mathrm{a}}{\text { total ar }}$ & $\frac{e a}{a}=\frac{130}{23}$ & $\frac{38}{9}=55$ \\
\hline
\end{tabular}

$\underline{\text { Runoff }}$

Storm Event 24 Hour Rainfall (inches) Runoff (inches)

10 year

5.0

5.5

6.5

7.1

1.3

1.6

2.3

50 year

100 year

2.7 


\section{Runoff Calculations}

Future Industrial Development

Unnamed Watershed Number 3

Hydrologic Soil Type

A
A
A
B
B
C

\section{Land Use}

Forest

Industrial

Residential

Forest

Residential

Industrial

Industrial

Quarry Development
Runoff Curve Area
Number (RCN)

25

33

50

55

75

91

81

81

61

5

15

8

103

239

Totals
$\mathrm{RCN}$ *

Area

625

2673

3050

275

1125

728

8343

Weighted $\mathrm{RCN}=\frac{\text { total } \mathrm{RCN} \text { area }}{\text { tatal area }}=\frac{16819}{230}=70$

\section{Runofe}

Storm Event

10 year

25 year

50 year

100 year
24 Hour Rainfall (inches)

5.0

5.5

6.5

7.1
Runoff (inches)

2.0

2.4

3.2

3.7 


\section{Discharge}

Unnamed Watershed Number 3

Area: 239 acres

Slope: 78

Adjustment factors:

Slope adjustment: $\quad 1.22$

Watershed shape adjustment: 1.2

Ponding adjustment:

Storm Event

$\begin{array}{cccc}10 & 25 & 50 & 100 \\ \text { year } & \text { year } & \text { year } & \text { year }\end{array}$

Central Ponding (28)

$\begin{array}{llll}.81 & .83 & .85 & .87\end{array}$

Design Point Ponding (10\%) $\quad .56 \quad .60 \quad .63 \quad .68$

Total Adjustments

$\begin{array}{llll}.66 & .73 & .78 & .87\end{array}$

Discharge for Present Conditions

\begin{tabular}{|c|c|c|c|c|}
\hline Storm Event & $\begin{array}{l}\text { Runoff } \\
\text { (Inches) }\end{array}$ & $\begin{array}{l}\text { Runoff } \\
\text { (cfs/In.) }\end{array}$ & Adjustments & $\begin{array}{c}\text { Discharge } \\
\text { (cfs) }\end{array}$ \\
\hline 10 year & 1.3 & 75 & .66 & 64 \\
\hline 25 year & 1.6 & 75 & .73 & 88 \\
\hline 50 year & 2.3 & 75 & .78 & 135 \\
\hline 100 year & 2.7 & 75 & .87 & 176 \\
\hline
\end{tabular}

Discharge for Future Industrial Development

\begin{tabular}{|c|c|c|c|c|}
\hline Storm event & $\begin{array}{l}\text { Runoff } \\
\text { (Inches) }\end{array}$ & $\begin{array}{l}\text { Runoff } \\
(\text { cfs/In.) }\end{array}$ & Adjustments & $\begin{array}{c}\text { Discharge } \\
\text { (cfs) }\end{array}$ \\
\hline 10 year & 2 & 95 & .66 & 125 \\
\hline 25 year & 2.4 & 95 & .73 & 166 \\
\hline 50 year & 3.2 & 95 & .78 & 237 \\
\hline 100 year & 3.7 & 95 & .87 & 306 \\
\hline
\end{tabular}




\section{Runoff Calculations \\ Present Conditions}

Unnamed Watershed Number 4

Hydrologic Soil Type

A
A
A
B
B
C
D
D

\section{Land Use}

Forest

Industrial

Residential

Forest

Residential

Forest

Forest

Residential

Quarry

Paved

Landfill

Roads
Runoff Curve

Number (RCN)

25

81

61

55

75

70

70

87

62

98

71

98

Totals

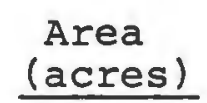

$\mathrm{RCN}$ *

Area

2600

648

2440

15

10

825

750

15

1050

10

700

261

110

10

15

10

6820

980

1065

980

Weighted $\mathrm{RCN}=\frac{\text { total } \mathrm{RCN} * \text { area }}{\text { total area }}=\frac{19119}{350}=55$

A weighted RCN of 60 will be used.

\section{Runoff}

\section{Storm Event}

24 Hour Rainfall (inches)

350

19,119

\section{0 year}

25 year

50 year

100 year
5.0

5.5

6.5

7.1
Runoff (inches)

1.3

1.6

2.3

2.7 


\section{Runoff Calculations}

Future Industrial Development

Unnamed Watershed Number 4

\begin{tabular}{|c|c|c|c|c|}
\hline $\begin{array}{l}\text { Hydrologic } \\
\text { Soil Type }\end{array}$ & Land Use & $\begin{array}{ll}\text { Punoff Curve } \\
\text { Number (RCN) } \\
\end{array}$ & $\begin{array}{l}\text { Area } \\
\text { (acres) }\end{array}$ & $\begin{array}{l}\text { RCN* } \\
\text { Area }\end{array}$ \\
\hline A & Forest & 25 & 54 & 1350 \\
\hline A & Industrial & 81 & 58 & 4698 \\
\hline A & Residential & 61 & 40 & 2440 \\
\hline B & Forest & 55 & 15 & 825 \\
\hline B & Residential & 75 & 10 & 750 \\
\hline C & Forest & 70 & 10 & 700 \\
\hline C & Industrial & 91 & 5 & 455 \\
\hline $\mathrm{D}$ & Forest & 70 & 10 & 700 \\
\hline D & Residential & 87 & 3 & 261 \\
\hline & Industrial & 81 & 110 & 8910 \\
\hline & Quarry Devel & pment & & \\
\hline & Paved & 98 & 10 & 980 \\
\hline & Landfill & 71 & 15 & 1065 \\
\hline & Roads & 98 & 20 & 980 \\
\hline & & Totals & 350 & 24,114 \\
\hline
\end{tabular}

Weighted $\mathrm{RCN}=\frac{\text { total } \mathrm{RCN} \text { *area }}{\text { total area }}=\frac{24114}{350}=69$

Runoff

Storm Event 24 Hour Rainfall (inches) Runoff (inches)

10 year

25 year

50 year

100 year
5.0

5.5

6.5

7.1
2.0

2.3

3. 1

3.6 


\section{Discharge}

Unnamed Watershed Number 4

Area: 350 acres

Slope: $8 \%$

Adjustment factors:

Slope adjustment: $\quad .78$

Watershed shape adjustment: 1.75

Ponding Adjustment:

$\begin{array}{lrrrl}\text { Storm Event } & 10 & 25 & 50 & 100 \\ & \text { year } & \text { year } & \text { year } & \text { year } \\ \text { Design Point Ponding (108) } & .56 & .60 & .63 & .68 \\ & .76 & .80 & .86 & .93\end{array}$

Discharge for Present Conditions

\begin{tabular}{|c|c|c|c|c|}
\hline Storm Event & $\begin{array}{l}\text { Runoff } \\
\text { (Inches) }\end{array}$ & $\begin{array}{l}\text { Runoff } \\
(\mathrm{cfs} / \mathrm{In} .)\end{array}$ & Adjustments & $\begin{array}{c}\text { Discharge } \\
\text { (cfs) }\end{array}$ \\
\hline 10 year & 1.3 & 160 & .76 & 158 \\
\hline 25 year & 1.6 & 160 & .80 & 205 \\
\hline 50 year & 2.3 & 160 & .86 & 316 \\
\hline 100 year & 2.7 & 160 & .93 & 402 \\
\hline
\end{tabular}

Discharge for Future Industrial Development

\begin{tabular}{|c|c|c|c|c|}
\hline Storm Event & $\begin{array}{l}\text { Runoff } \\
\text { (Inches) }\end{array}$ & $\begin{array}{l}\text { Runoff } \\
\text { (cfs/In.) }\end{array}$ & Adjustments & $\begin{array}{c}\text { Discharge } \\
\text { (cfs) }\end{array}$ \\
\hline 10 year & 2.0 & 200 & .76 & 304 \\
\hline 25 year & 2.3 & 200 & .80 & 368 \\
\hline 50 year & 3.1 & 200 & .86 & 533 \\
\hline 100 year & 3.6 & 200 & .93 & 670 \\
\hline
\end{tabular}




\section{Runoff Calculations \\ Present Conditions}

Unnamed Watershed Number 5

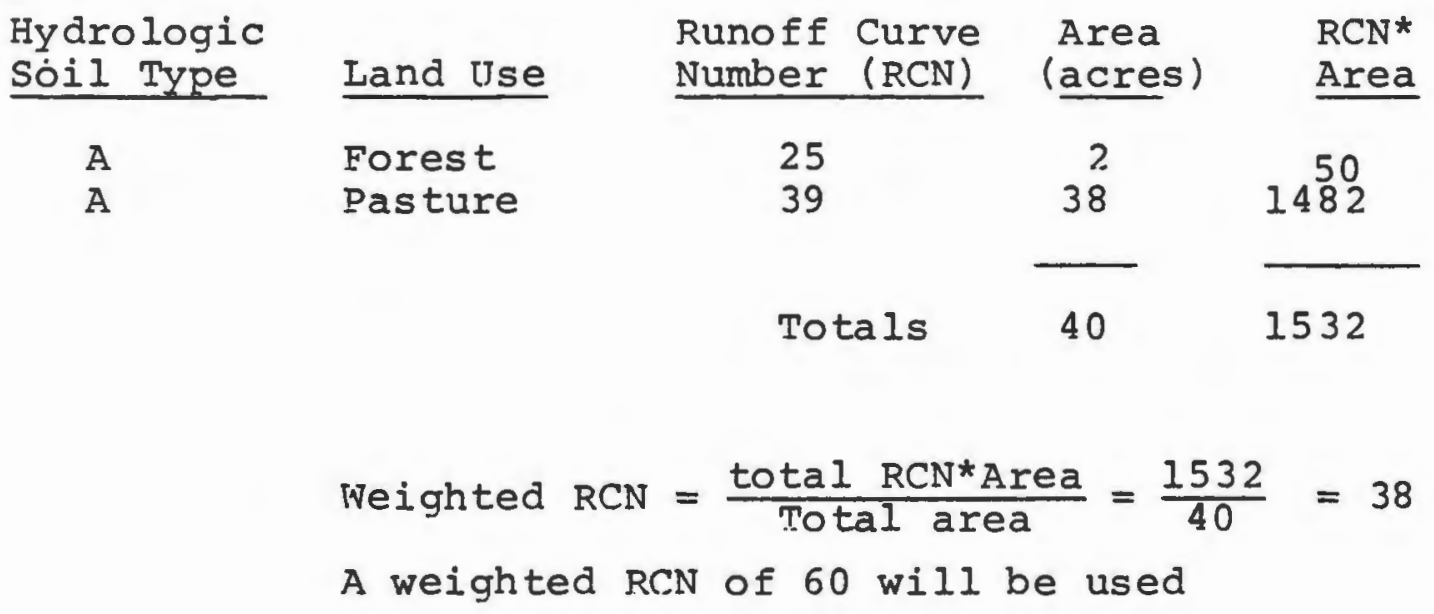

\section{Runoff}

Storm Event 24 Hour Rainfall (inches)

Runoff (inches)

10 year

5.0

25 year

5.5

1.3

50 year

6.5

7.1

1.6

2.3

2.7 


\section{Runoff Calculations}

Future Industrial Development

Unnamed Watershed Number 5

Hydrologic Soil Type

A

Land Use

Industrial
Totals

Runoff Curve Area

Number (RCN) (acres)

81

40

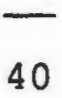

$\mathrm{RCN}$ *

Area

3240

3240

Weighted $\mathrm{RCN}=\frac{\text { total } \mathrm{RCN}^{*} \text { area }}{\text { total area }}=\frac{3240}{40}=81$

Runoff

\begin{tabular}{rrrr} 
Storm Event & 24 Hour Rainfall (inches) & Runoff (inches) \\
\hline 10 year & 5.0 & 3.0 \\
25 year & 5.5 & 3.4 \\
50 year & 6.5 & 4.4 \\
100 year & 7.1 & 4.9
\end{tabular}




\section{Discharge}

Unnamed Watershed Number 5

Area: 40 acres

Slope: 4 옹

Adjustment factors:

Watershed shape adjustment: 2.9

Total Adjustments: 2.9

Discharge for Present Conditions

\begin{tabular}{|c|c|c|c|c|}
\hline Storm Event & $\begin{array}{l}\text { Runoff } \\
\text { (Inches) }\end{array}$ & $\begin{array}{l}\text { Runoff } \\
(\mathrm{cfs} / I n .)\end{array}$ & Adjustments & $\begin{array}{c}\text { Discharge } \\
\text { (cfs) }\end{array}$ \\
\hline 10 year & 1.3 & 23 & 2.9 & 87 \\
\hline 25 year & 1.6 & 23 & 2.9 & 107 \\
\hline 50 year & 2.3 & 23 & 2.9 & 153 \\
\hline 100 year & 2.7 & 23 & 2.9 & 180 \\
\hline
\end{tabular}

Discharge for Future Industrial Development

\begin{tabular}{|c|c|c|c|c|}
\hline Storm Event & $\begin{array}{l}\text { Runoff } \\
\text { (Inches) }\end{array}$ & $\begin{array}{l}\text { Runoff } \\
(\mathrm{cfs} / \mathrm{In} .)\end{array}$ & Adjustments & $\begin{array}{c}\text { Discharge } \\
\text { (cfs) }\end{array}$ \\
\hline 10 year & 3.0 & 35 & 2.9 & 305 \\
\hline 25 year & 3.4 & 35 & 2.9 & 345 \\
\hline 50 year & 4.4 & 35 & 2.9 & 447 \\
\hline 100 year & 4.9 & 35 & 2.9 & 497 \\
\hline
\end{tabular}


Appendix C

Surface Water Monitoring

Monitoring Station Number SI

Parameter

Sampling Date
$6 / 26 / 80$
$8 / 5 / 80$
$10 / 14 / 80$
$1 / 20 / 81$

Temperature ${ }^{\circ} \mathrm{C}$ 25

30

10

0

D. O. $\mathrm{mg} / \mathrm{L}$

8.1

7.7

10.4

8.9

Turbidity

1.1

1.4

1.8

Color

1.5

40

25

susp. Solids

1

2

1

Total Phosphorus

0.05

0.05

0.05

$\mathrm{pH}$

7.4

8.0

7.2

Free Ammonia as $\mathrm{N}$

1.4

0.02

0.06

Nitrite as $\mathrm{N}$

0.02

0.02

0.02

Nitrate as $\mathrm{N}$

0.2

0.1

0.1

Alkalinity

17

27

31

Iron

0.19

0.31

0.36

Chlorophyll a, $\left(\mathrm{mg} / \mathrm{m}^{3}\right)$

1.6

5.9

6.4

MPN tc/100 ml

4

75

43

MPN fc/100 ml

3

9

9 
Monitoring Station Number $s 2$

\begin{tabular}{|c|c|c|c|c|}
\hline \multirow[t]{2}{*}{ Parameter } & \multicolumn{4}{|c|}{ Sampling Date } \\
\hline & $6 / 26 / 80$ & $8 / 5 / 80$ & $10 / 14 / 80$ & $1 / 20 / 81$ \\
\hline Temperature ${ }^{\circ} \mathrm{C}$ & 25.5 & 28.5 & 11 & \\
\hline $\mathrm{D} .0 . \mathrm{mg} / \mathrm{I}$ & 9.1 & 9.6 & 11.8 & \\
\hline Turbidity & 1.8 & 3.2 & 1.7 & \\
\hline Color & 15 & 35 & 25 & \\
\hline Susp. Solids & 2 & 3 & 1 & \\
\hline Total Phosphorus & 0.05 & 0.05 & 0.05 & \\
\hline $\mathrm{pH}$ & 6.9 & 7.3 & 7.0 & \\
\hline Free Ammonia as $\mathrm{N}$ & 0.12 & 0.19 & 0.10 & \\
\hline Nitrite as $\mathrm{N}$ & 0.02 & 0.02 & 0.02 & \\
\hline Nitrate as $\mathrm{N}$ & 1.0 & 0.5 & 0.7 & \\
\hline Alkalinity & 15 & 16 & 13 & \\
\hline Iron & 0.67 & 1.03 & 0.38 & \\
\hline Chlorophyll a, $\left(\mathrm{mg} / \mathrm{m}^{3}\right)$ & 3.6 & 2.3 & 1.6 & \\
\hline MPN tc/100 ml & - & 23 & 230 & \\
\hline MPN fc/100 ml & - & 21 & 230 & \\
\hline
\end{tabular}


Appendix D

State Water Quality Standards

Water Quality Criteria - The following physical, chemical and biological criteria are parameters of minimum water quality necessary to support the water use classifications of subsection 6.02 and shall be applicable to all waters of the state.

General Criteria - The following minimum criteria are applicable to all waters of the state, unless criteria specified for individual classes are more stringent. 1. At a minimum, all waters shall be free of pollutants in concentrations or combinations that will:

a) Adversely affect the composition of bottom aquatic life;

b) Adversely affect the physical or chemical nature of the bottom;

c) Interfere with the propagation of fish and shellfish; or

d) Undesirably alter the qualitative and quantitative character of the biota.

2. Aesthetics - All waters shall be free from pollutants in concentrations or combinations that:

a) Settle to form objectionable deposits;

b). Float as debris, scum or other matter to form nuis ances;

c) Produce objectionable odor, color, taste or turbidity; or,

d) Result in the dominance of nuisance species. 
3. Radioactive substances - The level of radioactive materials in all waters shall not be in concentrations or combinations which would be harmful to human, animal or aquatic life, or result in concentration in organisms producing undesirable conditions.

4. Nutrients - Nutrients shall not exceed the sitespecific limits necessary to control accelerated or cultural eutrophication.

5. Thermal Mixing Zones - In the case of thermal discharges into tidal rivers or estuaries, or fresh water streams or estuaries, where thermal mixing zones are allowed by the director, the mixing zone will be limited to no more than $1 / 4$ of the cross sectional area and/or volume of flow of river, stream or estuary, leaving at least $3 / 4$ free as a zone of passage. In wide estuaries and oceans, the limits of mixing zones will be established by the director. 
Criterion

6. Dissolved oxygen

7. Sludge depositssolia refuse-

floating solids-

oils-grease-scum

8. Color and turbidity

\section{Class A*}

$75 \%$ saturation, 16 hours/day, but not less than $5 \mathrm{mg} / 1$ at any time.

None allowable

None other than of natural origin. Not to exceed 5 Jackson Units (5JU).
None allowable

\section{Class B}

758 saturation, 16 hours/day, but not less than $5 \mathrm{mg} / 1$ at any time.

None in such ooncentrations that would impair any usages specifically assigned to this Class. Not to exceed $10 \mathrm{JU}$.

\section{Class C}

Minimum $5 \mathrm{mg} / \mathrm{l}$ any time. Normal seasonal and diurnal variations above 5 $\mathrm{mg} / \mathrm{l}$ will be maintained. For slugg ish eutrophic waters, not less than $4 \mathrm{mg} / 1$ at any time. Normal seasonal and diurnal variations above 4 $\mathrm{mg} / \mathrm{l}$ will be maintained.

Sludge deposits, floating solids, oils, grease and scum shall not be allowed except for such small amounts that may result from the discharge of appropriately treated sewage or industrial waste effluents.

None in such concentrations that would impair any usages specifically assigned to this Class. Not to exceed $15 \mathrm{JU}$.

\section{Class D}

A minimum of $2 \mathrm{mg} / \mathrm{l}$ at any time
None in such concentrations that would impair any usages specifically assigned to this Class. 


\section{Criterion}

9. Coliform bacteria

10. Fecal coliform bacteria/100 ml

11. Taste and odor

12. $\mathrm{pH}$

\section{Class $A^{*}$}

Not to exceed a median of 100 per $100 \mathrm{mI}$ nor more than 500

in more than 108 of samples collected.

A median of 20 per $100 \mathrm{ml}$, not more than 200 per $100 \mathrm{ml}$ in more than 10 \% of the samples collected.*

Nome other than of natural origin.

As naturally occurs.

\section{Class B}

Not to exceed a median of 1,000 per $100 \mathrm{ml}$ nor more than 2,400 in more than $20 \%$ of samples collected.

A median of 200 per $100 \mathrm{ml}$, not more than 500 per $100 \mathrm{ml}$ in more than 208 of the samples collected.*

None in such concentrations that would impair any usages specifically assigned to this

Class nor cause taste and odor in edible portions of fish.

None in such concentrations that would impair any usages specifically assigned to this Class nor cause taste and odor in edible fish.
Class D

None in such concentrations that would impair any usages specifically assigned to this Class.

Not applicable

None in such concentrations that would impair any usages specifically assigned to this Class.

6.5-8.0 or as $\quad 6.0-8.5 \quad 6.0-9.0$ 


\section{Criterion}

13. Allowable temperature increase

14. Chemical constituents

15. Phosphorus

\section{Class A*}

None other than of natural origin.

\section{Class B}

Only such

increases

that will not impair any useages specifically assigned to this Class.
Class C

Only such increases that will not impair any usages specifically assigned to this Class or causes the growth of unfavorable species of biota.
Class D

None except where the increase will not exceed the recommended limits on the most sensitive water use and in no case exceed $90^{\circ} \mathrm{F}$.

a. Waters shall be free from chemical constituents in concentrations or combinations which would be harmful to human, animal, or aquatic life for the appropriate most sensitive and governing water class use or unfavorably alter the biota.

b. In areas where fisheries are the governing considerations and approved limits have not been established, bioassays shall be performed as required by the appropriate agencies. The latest edition of the federal publication Water Quality Criteria will be considered the interpretation and application of bioassay result Bioassays shall be performed according to the latest edition of Standard Methods for the Examination of Water and Wastewater (APHA).

c. For public drinking water supplies, the limit prescribed by the United States Enviromental Protection Agency will be used where not superseded by more stringent state requirements.

None in such concentration that would impair any usages specifically assigned to said Class. New discharges of wastes containing phosphates will not be permitted into or immediately upstream of lakes or ponds. Phosphates shall be removed from existing discharges to the extent that such removal is or may become technically and reasonably feasible.

*Class A waters in use for drinking water supply may be subject to restricted use by state and local authorities.

*Guideline, pending further research. 


\section{Appendix E}

Ground-Water Monitoring

Parameter

Coventry Wel \# Cl

Mishnock Well Mishnock Well \# MI \# M2

\begin{tabular}{|c|c|c|c|}
\hline $\begin{array}{l}\text { TURBIDITY } \\
(\mathrm{S} . \mathrm{U} .)\end{array}$ & 0.5 & 0.5 & 0.6 \\
\hline $\begin{array}{l}\text { COLOR } \\
\text { (Apparent) }\end{array}$ & 0 & 4 & 2 \\
\hline $\begin{array}{l}\text { NITRATE } \\
\text { (As N) }\end{array}$ & 1.5 & 0.5 & 0.0 \\
\hline $\begin{array}{l}\text { CHLORIDE } \\
\text { (AS CI) }\end{array}$ & 49 & 37 & 13 \\
\hline $\mathrm{pH}$ & 5.7 & 5.7 & 5.7 \\
\hline $\begin{array}{l}\text { ALKALINITY } \\
\left(\mathrm{As} \mathrm{CaCO}_{3}\right)\end{array}$ & 8 & 5 & 3 \\
\hline $\begin{array}{l}\text { HARDNESS } \\
\left.(\mathrm{As} \mathrm{CaCO})_{3}\right)\end{array}$ & 44 & 24 & 18 \\
\hline FLUORIDE & 0.2 & 0.2 & 0.3 \\
\hline $\begin{array}{l}\text { IROII TOTAL } \\
\text { (As Fe) }\end{array}$ & 0.2 & 0.2 & 0.28 \\
\hline $\begin{array}{l}\text { MANGANESE } \\
\text { (As Mn) }\end{array}$ & 0.2 & 0.17 & 0.11 \\
\hline TOTAL SOLIDS & 177 & 110 & 64 \\
\hline SODIUM & 29.3 & 18.5 & 8.6 \\
\hline POTASSIUM & 4.2 & 1.8 & 1.6 \\
\hline CALCIUM & 12.8 & 7.2 & 5.6 \\
\hline MAGNESIUM & 2.9 & 1.5 & 1.0 \\
\hline SULFATE & 20.0 & 7.0 & 6.0 \\
\hline
\end{tabular}




\section{Appendix F}

Air Quality Monitoring and Standards

(w. Alton Jones Campus, West Greenwich)

Particulate Lead

Primary Standard: $1.5 \mathrm{ug} / \mathrm{m}^{3}$ (quarterly arithetic mean)

Secondary Standard: Same as primary standard

Calendar

Quarter

1
2
3
4
No. of

Observation

9

14

13

15
Quarterly Arithmetic Mean (ug/m3)

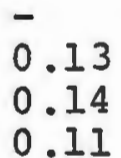

Sulfer Dioxide

Primary Standard: $80 \mathrm{ug} / \mathrm{m}^{3}$ (annual arithmetic mean), $365 \mathrm{ub} / \mathrm{m}^{3}(24 \cdot \mathrm{hr}$ average not to be exceeded more than once per year)

Secondary standard: $1300 \mathrm{ug} / \mathrm{m}^{3}$ ( $3 \mathrm{hr}$. average)

No. of observations 3650
Maximum $24 \mathrm{hr}$. Conc. $\left(\mathrm{ur} / \mathrm{m}^{3}\right)$

92

\section{ozone}

Primary Standard: $235 \mathrm{ug} / \mathrm{m}^{3}$ ( $1 \mathrm{hr}$ average with expected number of exceedances not greater than one).

Secondary Standard: Same as primary standard

No. of observations

7894
Maximum 1 hr Conc. $\left(\mathrm{ur} / \mathrm{m}^{3}\right)$
No. of violations

(I hr Std) 
Total Suspended Particulates

Primary Standard: $260 \mathrm{ug} / \mathrm{m}^{3}$ ( $24 \mathrm{hr}$ average not to be exceed more than once per year)

$75 \mathrm{ug} / \mathrm{m}^{3}$ (annual geometric mean)

Secondary Standard: $150 \mathrm{ug} / \mathrm{m}^{3}$ (24 hr average)
No. of Observations Maximum $24 \mathrm{hr}$ Conc. Annual Geometric $\left(\mathrm{ug} / \mathrm{m}^{3}\right) \quad$ Mean $\left(\mathrm{ug} / \mathrm{m}^{3}\right)$

51

67

20.4

Carbon Monoxide

Nitrogen Dioxide

A lack of reliable monitoring data prevents classification

of the site for these pollutants. 
Appendix G

NEW SOURCE REVIEW

Two basic strategies are involved to control and reduce air pollution from stationary sources such as factories, utilities, petroleum facilities, and other industrial or municipal concerns. The first is to reduce pollution from existing sources of air pollution and the second is to make certain that new stationary sources of air pollution are constructed to make them pollute as little as possible. This will be accomplished through the "New Source Review" program.

The 1977 amendments to the Clean Air Act are the basis for the current New Source Review program. These amendments provide new options for states and localities that will allow for economic growth and development in polluted areas while reducing air pollution in a consistent manner. Areas with polluted air are defined as "nonattainment areas." 1 Prior to 1977, the Clean Air Act afforded no latitude for new sources of pollution in nonattainment areas, a condition that was clearly unreasonable, particularly in older urban and industrial areas where new development is so critically needed.

\footnotetext{
1 Nonattainment areas are defined as areas where one or more of six air pollutants are in violation of federal health standards. It is possible for an area to be attairment for some of these pollutants and nonattainment for others. For example, Rhode Island is currently attairment for sulfur dioxide. That is, it meets federal health standards for this pollutant. At the same time, the entire state is nonattairment for ozone polilution which comes from both stationary sources and motor vehicles. Some areas of the state may also be nonattainment for carbon monoxide, a highly localized air pollutant formed by the incomplete combustion of fuel in motor vehicles.
} 
States and localities will now be able to construct new sources of air pollution provided that certain conditions are met through the New Source Review Program. The three main conditions are:

(1) The new source(s) must install control equipment that will ensure the maximum amount of emission reductions.

(2) There must be a corresponding reduction from other existing sources in the area which is greater than the pollution that will be emitted from the new sources and/or

(3) There must be an areawide reduction in air pollution which could come from a number of unrelated sources. These would have to be of sufficient magnitude to insure steady progress in reducing an area's air pollution even with contruction of the new stationary source: Specific strategies to accomplish these objectives in the New Source Review program include emission offsets and banked emissions. ${ }^{2}$ These strategies can be applied in different ways depending on local development needs and the severeness of an area's air quality problems.

An emission offset is an emission reduction made at an existing source of pollution to allow a new source to operate in the area. Banked emissions are those emissions saved to provide offsets for a source seeking a permit in the future. 


\section{Benefits of New Source Review}

The basic purpose for New Source Review is to allow for orderly growth in either attainment or nonattainment areas while air quality standards are belng attained or mantained. New Source Review provides the air agency a tracking mechanism with which an accurate inventory of emissions can be maintained from new sources coming into Rhode Island or from growth from existing sources. It also allows a great deal of flexibility in planning future growth through such innovative techniques as emission offsets and banked emissions.

New Source Review pertains to new and modified emissions sources of significant size. Operating permits will be conditioned upon certain operating parameters (discussed earlier) and will be issued after air quality impact analyses are performed. The possibility of permit fees as revenue sources is currently under consideration.

The final and most overriding benefit of implementing New Source Review is that without it, no new source growth can be permitted in the state.

\section{Potential Problems and/or Unknowns}

At present, legal authority to proceed with New Source Review, and operating permits in particular, is not in hand. Last year's attempt to obtain legal authority, via the state legislature, was unsuccessful. Without major, visible 
political support, the fate of the bill this session won't be much brighter. The consequences of no action are considerable. If the legislature doesn't approve operating permit authority, no new major sources will be allowed to enter Rhode Island and existing sources will not be allowed to expand. New Source Review is an unusually comprehensive regulatory program and industries and various interest groups may also balk at the suggestion of permit fees.

on the planning and administration level, permit enforcement will require additional manpower, in all likelihood. As a backdrop to the entire set of scenarios is the question of the position of the U.S. Environmental Protection Agency $(E P A)$ : will it use its power to impose sanctions if the state does not have New Source Review in effect this year.

\section{Interested and Affected Constituents}

(a) The Rhode Island State Legislature will be instrumental since it must pass legislation giving the Department of Environmental Management (DEM) the necessary authority to proceed with the program.

(b) U.S. EPA will follow the proceedings closely, since it is required by law to prevent any major new sources in nonattainment areas if the state does not adopt New Source Review. EPA has accordingly made the adoption of New Source Review a condition for approval of the entire state Implementation Plan (SIP). 
(c) Major industries will be affected whatever the outcome. No New Source Review program can bring economic sanctions on the state, while adoption of the program will bring new operating conditions. On the positive side, adoption of New Source Review will "force" technology: that is, new and innovative approaches to reduce pollution will be tried, in order to take advantage of emissions offsets and banking, where they may not have been considered cost-effective before. At the moment, two large firms in the state which were granted construction permits this year are in "limbo" awaiting the outcome which will determine the status of their permits. The business community in Rhode Island, in general, will be affected by New Source Review, adopted or not, via the gain or loss of secondary employment and cash flow generated by industrial activity.

(d) State and local chambers of commerce and other economic interest groups need to be informed of the New Source Review program and the consequences that could occur if it is not adopted in Rhode Island. The influence of these groups on the legislative process will not be underrated.

(e) State agencies including the Rhode Island Department of Economic Development will be affected because of the impact the program will have on economic projections and development plans for the state. Local governments, whose tax bases will be affected by the industrial growth policies, will also be involved. Statewide Planning will also be affected. 
(f) Health and environmental coalitions will be interested in the expedient attainment of air quality standards that a New Source Review program will facilitate.

\section{Public Participation Strategy by DEM}

As mentioned earlier, the most important task is to inform interested and affected constituencies of the purpose and scope of New Source Review, and especially the consequences of not adopting the program. Key members of the state legislature and the business and economic community will be urged to attend meetings of the stationary source Advisory Committee, at which in-depth discussions of the proposals will take place. The SIP Newsletter will also be used to present the issue and the divergent views held. Other techniques will be considered, depending on the outcome of the upcoming legislative session. 


\section{FOOTNOTES}

Industrial zoning Guidelines (Providence: Rhode Island Statewide Planning Program, 1980), p. $4-6$.

${ }^{2}$ Gordon R. Archibald, Inc., Transportation Improvements in the Vicinity of Hopkins Hill Road, West Greenwich Coventry, R.I. (Providence: Rhode Island Department of Transportation, 1980), p. 79 .

$$
\begin{aligned}
& { }^{3} \text { Ibid., p. I-22. } \\
& { }^{4} \text { Ibid., p. } 21 .
\end{aligned}
$$

${ }^{5}$ National Climatic Center, Local Climatological Data, Annual Summary with Comparative Data, 1979, Providence, Rhode Island. (Washington, D.C.: U.S. Department of Commerce, 1979).

${ }^{6}$ Hiram J. Smith, Surficial Geology of the Crompton Quadrangle (Washington, D.C.: U.S. Geological Survey, 1956).

${ }^{7}$ Rhode Island Soil Interpretation Tables (West Warwick, Rhode Island: U.S. Department of Agriculture, 1975).

${ }^{8}$ Joseph Kuckich, Pawtuxet River Basin, Minerals (Washington, D.C.: U.S. Department of the Interior, 1973), p. 5-6.

$$
{ }^{9} \text { Ibid., p. } 9 \text {. }
$$

${ }^{10}$ Urban Hydrology for Small Watersheds (Washington, D.C.: U.S. Department of Agriculture, 1975).

${ }^{11}$ S.M. Lang, Appraisal of the Ground-Water Reservoir Areas in Rhode Island Thashington, D.C.: U.S. Geological Survey, 1961).

\section{William B. Allen et al., Ground-Water Map of the} Crompton Quadrangle, Rhode Island Washington, D.C.: U.S. Geological Survey, 1959).

${ }^{13}$ Ecological Associates, Inc., Transportation Improvements, Vicinity - Hopkins Hill Road, Coventry and West Greenwich, Rhode Island, Environmental Studies (North Kingstown, R.I. 1980, p. 13 .

$$
{ }^{14} \text { Ibid., p. 11-13. }
$$


${ }^{15}$ Ibid., p. 13-14.

16 J.E. Wesler, Manual for Highway Noise Prediction (Washington, D.C.: Federal Highway Administration, 1972), p. 1-67.

17 Archibald Transportation Improvements in the Vicinity of Hopkins Hill Road, West Greenwich - Coventry, R.I., p. 26.

${ }^{18}$ Ibid., p. 27.

${ }^{19}$ W. H. Wischmeier and D. D. Smith, Predicting Rainfall

Erosion Losses, A Guide to Conservation Planning (Washington, D.C.: U.S. Department of Agriculture, 1978).

${ }^{20}$ Kuckich Pawtuxet River Basin, Minerals, p. 18. 


\section{BIBLIOGRAPHY}

Ahmed, Riaz. A Manual for Assessment of Nonpoint Sources of Water Pollution Hartford: Center for the Environment and Man, 1979 .

Allen, William B.; Johnson, Karl E.; and Mason, Robert A. Ground-Water Map of the Crompton Quadrangle, Rhode Island. Washington, D.C.: U.S. Geological Survey, 1959.

Archibald, Gordon R. Transportation Improvements in the Vicinity of Hopkins Hill Road, West Greenwich-Coventry, R. I. Providence: Rhode Island Department of Transportation, 1980.

Brooks, Richard Oliver. Municipal Environmental ordinances. 2 vols. Kingston: University of Rhode Island.

Cushman, Mitchell. Rural Development Strategies for the State of Rhode Island. Kingston: Intergovernmental Policy Analysis Program, University of Rhode Island, 1980 .

Ecological Associates, Inc. Transportation Improvements, Vicinity - Hopkins Hill Road, Coventry and West Greenwich, Rhode Island. North Kingstown, Rhode Island: 1980 .

Industrial Zoning Guidelines. Providence: Rhode Island Statewide Planning Program, 1980.

Interim Soil Survey Report for Coventry, Rhode Island. West Warwick, Rhode Island: USDA, Soil Conservation Service, 1976.

Interim Soil Survey Report for West Greenwich, Rhode Island: West Warwick, Rhode Island: USDA, Soil Conservation Service, 1976.

Kuckich, Joseph. Pawtuxet River Basin Minerals. Washington, D.C.: U.S. Department of the Interior, 1973.

Lang, S.M. Appraisal of the Ground-Water Reservoir Areas in Rhode Island. Washington, D.C.: U.S. Geological Survey, 1961.

National Climatic Center. Local Climatological Data, Annual Summary with Comparative Data, 1979, Providence, Rhode Island. Washington, D.C.: U.S. Department of Commerce, 1979. 
Rhode Island Erosion and Sediment Control Handbook. West Warwick, Rhode Island: USDA, Soil Conservation Service, 1980 .

Rhode Island Soil Interpretation Tables. West Warwick, Rhode Island: USDA, Soil Conservation Service, 1975.

Rosen, Sherman T. Manual for Environmental Impact Evaluation. Englewood Cliffs, New Jersey: Prentice Hall, Inc., 1976.

Smith, Hiram J. Surficial Geology of the Crompton Quadrangle. Washington, D.C.: U.S. Geological Survey, 1956 .

Urban Hydrology for Small watersheds. Washington, D.C.: U.S. Department of Agriculture, 1975.

Wesler, J. E. Manual for Highway Noise Prediction. Washington, D.C.: Federal Highway Administration, 1972 .

Wischmeier, W.H. and Smith, D.D. Predicting Rainfall Erosion Losses, A Guide to Conservation Planning. Washington, D.C.: U.S. Department of Agriculture, 1978. 